\title{
Trajnostno upravljanje s turistično destinacijo Mediteranska Slovenija
}

Uredil Marko Kukanja 


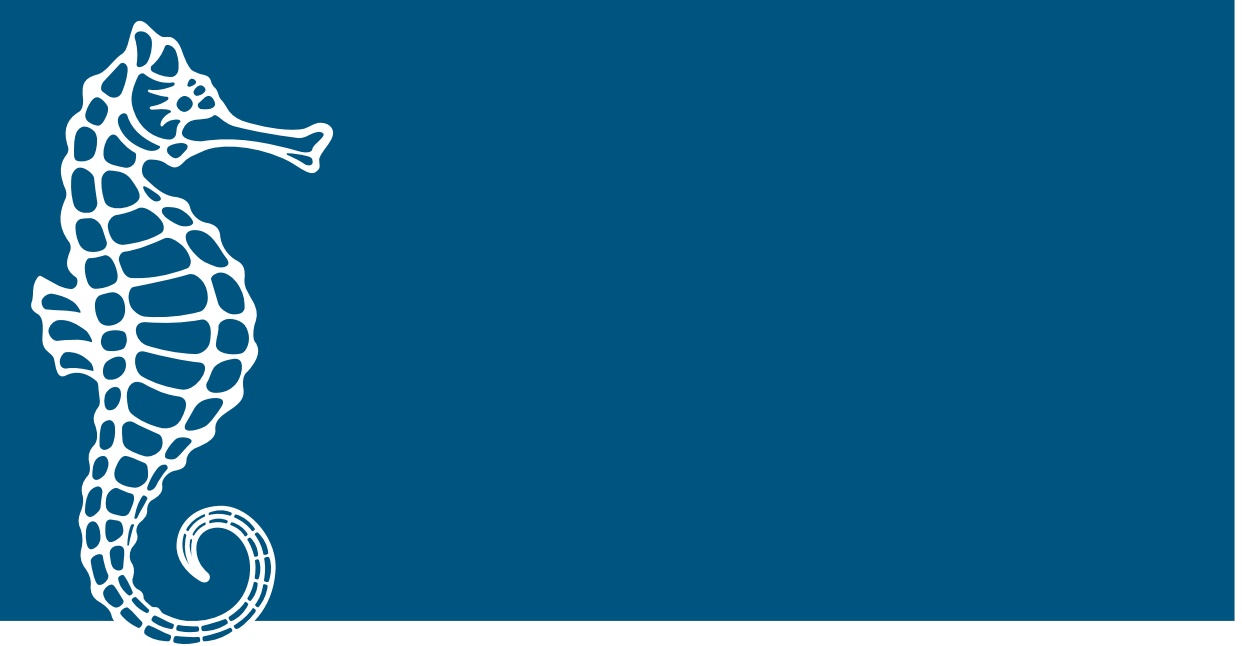

Založba Univerze na Primorskem

\section{Uredniški odbor}

Silva Bratož

Aleksandra Brezovec

Janko Gravner

Alen Ježovnik

Maja Meško

Ana Petelin

Gregor Pobežin

Krstivoje Špijunović

Jonatan Vinkler

Vito Vitrih

Miloš Zelenka

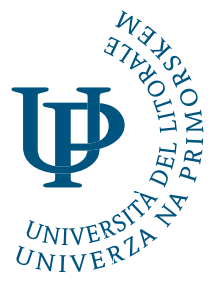




\section{Trajnostno upravljanje s turistično destinacijo Mediteranska Slovenija}

Uredil Marko Kukanja

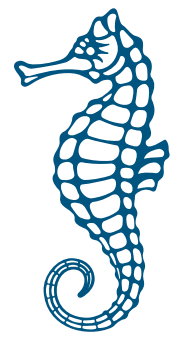




\section{Interreg ADRION ADRIATIC-INIAN}

European Regional Development Fund - Instrument for Pre-Accession II Fund

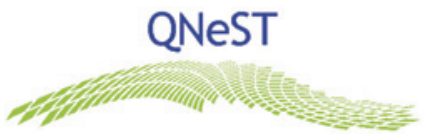

Naslov projekta/Project Title • Quality Network on Sustainable Tourism (QNesT) Vodilni partner/Lead Partner . Università del Salento

Projektni partnerji/Project Partners - up Fakulteta za turistične študije - Turistica,

Chamber of Commerce \& Industry of Xanthi, Technological Educational institute of Epirus,

Regional Union of the Chamber of Commerce of Veneto - Eurosportello, Ministry of Economy

- Directorate for Development of smes of Montenegro, Istrian Development Agency Ltd,

Labirinto Social Cooperative

Projekt je sofinanciran v okviru razpisa INTERREg v-в Transnational Adriatic-Ionian

Programme 2014-2020. Programme Priority: 2 - Sustainable Region.

Skupna vrednost projekta: 1.465.662,95 EUR.

The project is co-financed within the INTERREg V-B Transnational

Adriatic-Ionian Programme 2014-2020. Programme Priority: 2 - Sustainable Region.

Total project value: 1,465,662.95 EUR.

Vsebina publikacije ne odraža nujno uradnih stališč Evropske unije.

Za vsebino publikacije je/so odgovoren/-ni izključno avtor/-ji.

The content of this publication does not necessarily reflect the official positions

of the European Union. The responsibility for the content of this

publication belongs to the author(s).

Trajnostno upravljanje s turistično destinacijo

Mediteranska Slovenija

Uredil Marko Kukanja

Recenzenta Almir Peštek in Matej Vranješ

Izdala in založila Založba Univerze na Primorskem

Titov trg 4, Koper · www.hippocampus.si

Glavni urednik Jonatan Vinkler

Vodja založbe Alen Ježovnik

(C) 2019 Univerza na Primorskem

Koper, Januar 2019

http://www.hippocampus.si/ISBN/978-961-7055-46-7.pdf

http://www.hippocampus.si/ISBN/978-961-7055-47-4/index.html

https://doi.org/10.26493/978-961-7055-46-7

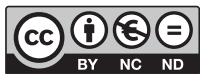

Kataložni zapis o publikaciji (CIP) pripravili

v Narodni in univerzitetni knjižnici v Ljubljani

COBISS.SI-ID $=298684672$

ISBN 978-961-7055-46-7 (pdf)

ISBN 978-961-7055-47-4 (html) 


\section{Kazalo}

1 Mediteranska Slovenija: Predstavitev destinacije in potencialov turističnega razvoja

Simon Kerma in Maja Trošt · 7

2 Trajnostno upravljanje $\mathrm{z}$ destinacijo: oblikovanje certifikacijske sheme za območje Mediteranske Slovenije

Marko Kukanja 37

3 Družbena odgovornost: pogledi deležnikov na delovanje turističnih podjetij v Občini Piran

Tanja Planinc in Zorana Medarić · 81 



\section{Mediteranska Slovenija: \\ Predstavitev destinacije \\ in potencialov turističnega razvoja}

\section{Simon Kerma in Maja Trošt}

Obalno-kraška statistična regija je ena od dvanajstih statističnih regij Slovenije in je edina regija v Sloveniji, ki ima izhod na morje. Obsega občine Divača, Hrpelje-Kozina, Izola, Komen, Piran, Sežana, Ankaran ter Mestno občino Koper. Regijo uvrščamo v makro destinacijo Mediteranska Slovenija, Mediteran oz. sredozemski svet, ki leži v jugozahodni Sloveniji. Med najpomembnejše značilnosti te destinacije spadajo krajinska raznolikost, kraška naravna čudesa, privlačna in zlahka dostopna mediteranska mesta, tesno povezana z zelenim istrskim podeželjem, podzemna doživetja svetovnega formata, $\mathrm{v}$ simbiozi s kulinaričnimi dobrotami in z vrhunskimi vini. Regijo pa zaznamujejo obmorska lega z značilnimi dejavnostmi, med katere uvrščamo pomorstvo, turizem in kmetijstvo, usmerjeno v zgodnje pridelke in posebne poljedelske kulture (npr. oljke), tipična poselitev v gručastih naseljih, litoralizacija in drugo.

Zaradi vseh omenjenih značilnosti smo se odločili, da jo podrobneje preučimo tako $\mathrm{z}$ geografskega vidika kot tudi s socioekonomskega. V prvem delu tako predstavljamo geografske značilnosti regije, regionalne opredelitve in poimenovanja, podnebje in naravno vegetacijo, elemente flišnih in kraških pokrajin, Tržaški zaliv ter naravne vrednote, zavarovana območja in kulturno dediščino. V drugem delu, kjer smo se oprli na socio-ekonomske dejavnike, 
pa prikazujemo osnovne podatke o regiji, prometno omrežje, turistični profil regije, značilnosti turizma in nadaljnje težnje, strateške politike v povezavi s turizmom, inovativne tehnologije, sisteme in aplikacije ter potencialne možnosti za lokalna podjetja.

\section{Glavne geografske značilnosti Mediteranske Slovenije}

Mediteran oz. sredozemski svet leži v jugozahodni Sloveniji, njegove glavne značilnosti pa so menjavanje flišnih in apneniških kamnin, razmeroma toplo submediteransko podnebje, obmorska lega z značilnimi dejavnostmi, kot so pomorstvo, turizem, v zgodnje pridelke in posebne poljedelske kulture (npr. oljke) usmerjeno kmetijstvo, tipična poselitev v gručastih naseljih in tudi litoralizacija, proces zgoščanja prebivalstva in dejavnosti v ozkem priobalnem pasu. Od sosednje (kontinentalnejše) regije višjega dinarskega sveta se obravnavano območje loči po razlikah v podnebju, rastju in gospodarstvu, čeprav meja v naravi niti ni tako izrazita. V sredozemski svet zato načeloma uvrščamo tiste predele, kjer se povprečna temperatura najhladnejšega meseca ne spusti pod ledišče. Gre torej za pokrajine, ki se bolj ali manj neposredno naslanjajo na Tržaški zaliv in Furlansko nižino. Južna meja Mediteranske Slovenije sledi državni meji s Hrvaško, medtem ko jo na zahodu omejuje državna meja z Italijo. Pokrajina s podobnimi lastnostmi se nadaljuje preko administrativnih razmejitev tudi v sosednjih državah. Meja med sredozemskim in pretežno celinskim dinarskim svetom proti notranjosti Slovenije v naravi torej ni tako jasna. Naslanja se predvsem na robove visokih kraških planot $\mathrm{z}$ značilno dinarsko smerjo od severozahoda proti jugozahodu. Za sredozemski svet je značilna notranja pokrajinska pestrost, ki je posledica raznolikega površja z izrazito reliefno energijo in dinamiko, kar posledično vpliva tudi na druge pokrajinske prvine in prilagoditve človeka. V celoti gledano sestavlja sredozemsko makroregijo šest kopnih in ena morska pokrajina (Repolusk, 1998).

\section{Regionalne opredelitve in poimenovanja}

Območje mediteranskega dela Slovenije je po različnih geografskih delitvah (regionalizacijah) opredeljeno predvsem z dvema ključnima elementoma: Jadranskim morjem in (sub)mediteranskim podnebjem. Melikova regionalizacija iz leta 1954 ta prostor poimenuje Koprsko primorje, Ilešičeva iz leta 1958 Primorske pokrajine oz. Su- 
bmediteranske pokrajine, Gamsova iz leta 1983 določa Primorje ali submediteransko Slovenijo, medtem ko naravnogeografska regionalizacija več avtorjev z Geografskega inštituta zRC SAZU iz leta 1998 opredeli makroregijo Sredozemski svet (Perko in Kladnik, 1998). Žiberna, Natek in Ogrin so leta 2009 v svoji naravnogeografski členitvi Slovenije mediteranski prostor nekoliko natančneje opredelili kot Obsredozemske pokrajine (flišna gričevja, hribovja in doline, kraški ravniki, podolja in hribovja ter Jadransko morje), medtem ko je Plut istega leta v sonaravni regionalizaciji Slovenije sredozemski svet razmejil na Severno in Južno Primorsko, slednjo pa razdelil na Slovensko Istro ter Kraško-brkinsko mezoregijo (Ogrin in Plut, 2009; Ogrin, 2013).

V prispevku smo se omejili na analizo območja obalno-kraške statistične regije, ki geografsko gledano v celoti spada v mediteransko Slovenijo. Južni del regije administrativno združuje štiri občine: Ankaran, Koper, Izolo in Piran (vključno z morskim akvatorijem). Geografsko ta prostor pripada severnemu delu istrskega polotoka, zato se je v rabi postopoma uveljavilo tudi poimenovanje Slovenska Istra. Ozemlje Slovenske Istre omejuje državna meja (na jugu s Hrvaško in na severu z Italijo), na zahodu in vzhodu pa je območje omejeno z naravno mejo - že omenjenim Tržaškim zalivom in kraškim robom. Severni in vzhodni del obalno-kraške regije administrativno vključuje občine Divača, Hrpelje-Kozina, Komen in Sežana. Do leta 1995 so vse štiri sestavljale enotno sežansko občino, ozemlje današnjih samostojnih občin pa se v celoti prekriva z območjem Upravne enote Sežana.

\section{Podnebje in naravna vegetacija}

Kot predhodno zapisano, je natančnejša naravnogeografska opredelitev Mediterana v Sloveniji definirala in poimenovala Obsredozemske oz. Submediteranske pokrajine. Slednje obsegajo prostor jugozahodnega dela Slovenije na obrobju sredozemskega bazena, ki je reliefno odprt proti Jadranskemu morju oz. Tržaškemu zalivu. Te pokrajine imajo zaradi vpliva morja milejše podnebje od tistih v notranjosti države, a v povprečju še vedno nekoliko hladnejše in vlažnejše od pravega sredozemskega podnebja, zato tudi govorimo o zmernem sredozemskem oz. submediteranskem podnebju. Te razlike se odražajo tudi v rastlinstvu, saj je tisto pravo sredozemsko zimzeleno, zmerno sredozemsko pa pretežno listopadno, z razvejanim korenin- 
skim sistemom, kar tudi omogoča preživetje v ekstremnih razmerah (Ogrin, 2013).

Prehodni značaj pokrajin z mešanjem submediteranskih in celinskih vplivov je močno vplivala na biotsko pestrost flore in favne. Samo na območju Slovenske Istre so našteli kar 1.688 živalskih vrst, med katerimi je 28 endemitskih vrst. Naravni gozd porašča predvsem vzhodna območja ter za kmetijstvo manj primerna osojna pobočja. Gozdovi v Slovenski Istri nimajo večje ekonomske vloge in gozdarstvo ter z njim povezane aktivnosti ne predstavljajo pomembnejših gospodarskih dejavnosti, kar dodatno otežuje tudi majhnost in razdrobljenost posesti. Gozdovi imajo predvsem izrazito ekološko vlogo. Med ekološkimi funkcijami oz. storitvami je najizrazitejša varovalna funkcija, ki se pojavlja na ekstremnejših delih gozdnih rastišč v celotnem območju Slovenske Istre. Varovalni funkciji po pomembnosti sledijo biotopska, hidrološka in klimatska funkcija. Vedno pomembnejša pa je socialna funkcija gozdov, ki jo lahko povežemo tudi s turizmom (LAs Istre, 2018).

Na območju Krasa in Brkinov veliko težavo predstavljajo pretežno visok delež mladih gozdov, pojavljanje številnih bolezni in gradacija žuželk ter velika požarna ogroženost. V povprečju se vsako leto pojavi vsaj 50 gozdnih požarov. Pestrost gozdov je, kljub prisotnosti monokulture črnega bora in drugih iglavcev, izredno velika, saj je prisotna sukcesija. Tu najdemo 42 drevesnih vrst (združba hrasta gradna in jesenske vilovine; črni gaber, mali jesen, puhasti hrast, graden, beli gaber ...). Še veliko več pa je grmovnih (navadni ruj, brin, leska, rešeljika, črni trn, rumeni/rdeči dren, navadni šipek, mali jesen, brestovolistna robida ...) in ostalih rastlinskih vrst. Na območju Brkinov večino gozdne vegetacije predstavljajo gozdovi bukve, različnih hrastov in kostanja. Na območju Slavnika in Čičarije (nad 800 $\mathrm{m}$ nadmorske višine) prevladuje bukev, manj je jelke in smreke, $\mathrm{v}$ nižjih legah (60o do $800 \mathrm{~m}$ nadmorske višine) poleg bukve najdemo še črni in beli gaber, še nižje pa prevladujejo degradirana grmišča hrasta - kraška gmajna (LAs Krasa in Brkinov, 2016).

\section{Elementi flišnih in kraških mediteranskih pokrajin}

Za mediteranski del Slovenije sta značilna prepletanje oz. izmenično prehajanje flišnih in kraških pokrajin ter seveda morski akvatorij - Tržaški zaliv. Kamninsko in reliefno je sredozemski svet raznolik in precej razčlenjen. Med tipi površja so dokaj enakomerno zasto- 
pane ravnine, gričevja, hribovja (najvišje vzpetine segajo v Čičariji prek $1.000 \mathrm{~m}$ nad morjem), nizke kraške planote in podolja ter vale in seveda morska kotanja Tržaškega zaliva. Človek se je skozi dolga zgodovinska obdobja prilagajal pokrajinskim danostim in oblikoval značilno kulturno pokrajino. Ta je v sredozemskem svetu med najstarejšimi v Sloveniji. Zlasti velja omeniti kulturne terase v flišnih gričevjih, suhozid in t.i. »delani kras« na zakraselem površju ter antropogeno spreminjanje morske obale (Repolusk, 1998).

Fliš (eocenske starosti) je za vodo nepropustna, hitro razpadajoča kamnina, ki tvori debelo preperelino. Sestavljata ga lapor in peščenjak z vložki apnenca. Prepletanje posameznih plasti je lahko zelo različno. Flišna območja obsegajo skoraj polovico vsega sredozemskega sveta (Repolusk, 1998). Med flišne obsredozemske pokrajine spadajo gričevnata Goriška in Vipavska brda ter z rečnimi nanosi zapolnjena Vipavska dolina in njeno nadaljevanje Goriško polje, ki pa so vsi izven obalno-kraške statistične regije, zato jim v nadaljevanju ne namenjamo večje pozornosti. Za obravnavano območje relevanthe flišne pokrajine so tako gričevnata Koprska brda V Slovenski Istri ter hribovje Brkini z dolino Reke in Vrhe. Značilna je močna razčlenjenost površja s širokimi slemeni in z globokimi ter ponekod tudi ozkimi dolinami s strmimi pobočji (Ogrin, 2013).

V istrskem delu so vodotoki Osapska reka, Rižana, Badaševica, Drnica, Dragonja in drugi razrezali mehke flišne kamnine v hrbte, za katere so značilna položna temena in strma pobočja. Med hrbti se v večini nahajajo ozke in strme rečne doline, ki se razširijo šele v spodnjih akumulacijskih delih. Povirni predeli Dragonje, Rokave in pregarskih ponikalnic so najvišji flišni predeli na tem območju. Prevladujejo gručaste vasi, ki se večinoma nahajajo na pomolu (Krkavče, Koštabona, Glem, Labor, Truške, Padna), v sedlu (Babiči, Dvori) ali na slemenu (Pomjan, Marezige). Ozke doline so v glavnem neposeljene (Repolusk, 1998; LAs Istre, 2018).

V Slovenski Istri velja omeniti še akumulacijske ravnice, ki so dejansko najmanjša enota z najnižjimi nadmorskimi višinami ter najbolj ravninskimi deli. K tej enoti se prištevajo tudi Sečoveljske in Strunjanske soline ter bonifiki v Kopru in pod Srminom. Najobsežnejše ravnice so ob izlivih večjih rek, še posebej ob izlivu Dragonje. Ob srednjih in zgornjih tokovih so precej ozke in tudi nekoliko višje. Kot posebnost lahko omenimo t.i. vale (Movraška, Gračiška, Lukinska in Sočerska), ki so nastale na stiku med kraškim in flišnim delom. 


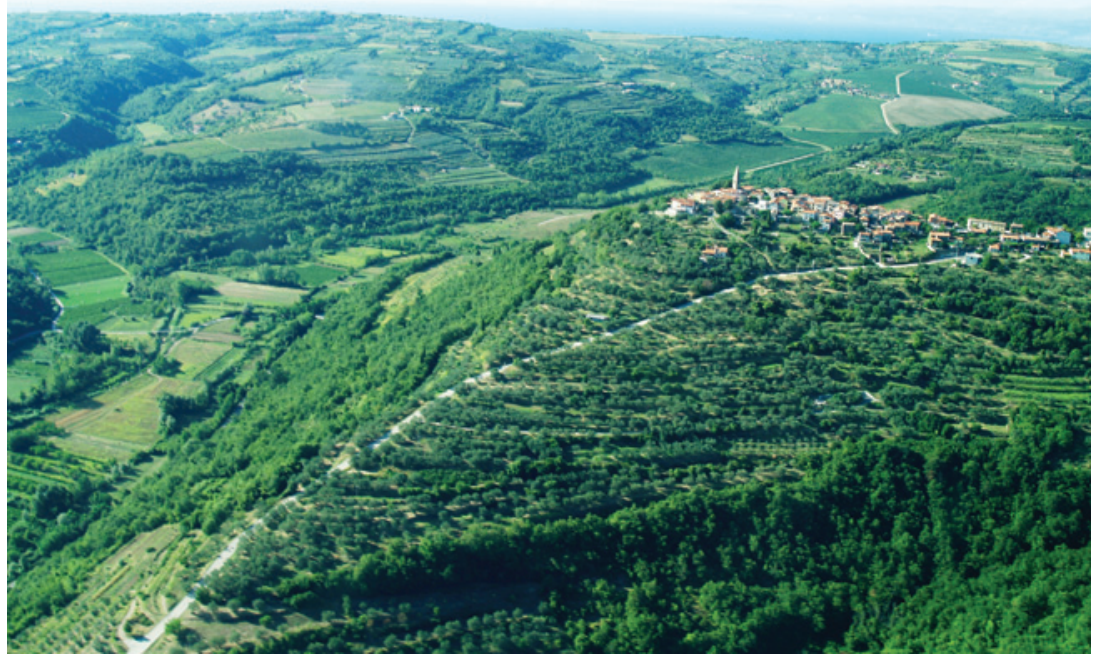

Slika 1.1 Značilna istrska pokrajina flišnega gričevja s slikovito vasico Padna na pomolu (avtor Simon Kerma)

Gre za ravnice z obliko kraških depresij ali fluviokraških podolij, ki ležijo tudi do $300 \mathrm{~m}$ visoko nad morjem (LAs Istre, 2018).

Brkini z dolino Reke so v celoti gledano precej velika flišna pokrajina, vendar v obalno-kraško regijo spadajo zgolj zahodni del (v občinah Divača in Hrpelje-Kozina). Gre za približno $30 \mathrm{~km}$ dolgo in do $10 \mathrm{~km}$ široko razpotegnjeno hribovje, ki na vzhodu meji na dolino reke Pivke in Snežnik, na jugu na Čičarijo, na severovzhodnem robu pa je dolina, ki spremlja tok $55 \mathrm{~km}$ dolge ponikalnice Reke, ki je ob prehodu s fliša na apnenec izdelala našo največjo slepo dolino in pred ponorom v Škocjanskih jamah še slikovito sotesko (Repolusk, 1998). Brkini se delijo na tri dele: zahodne, osrednje in vzhodne. Osrednji in zahodni Brkini so hriboviti (nad vasjo Artviže segajo prek $800 \mathrm{~m}$ nad morjem), vzhodni del pa zaradi manjših višinskih razlik bolj spominja na gričevje. Sem spadajo še Ilirskobistriška kotlinica in rodovitna Vremska dolina ter številne slepe doline na jugozahodu hribovja ob stiku fliša s krasom. Naselja v Brkinih imajo značilno slemensko lego. Postavljena so tam, kjer je sleme bolj ozko in strmo, v vzhodnih Brkinih pa predvsem na vrhu kopastih vzpetin. Prav tako 
so naselja tudi v bližini slepih dolin, ki so predstavljale oaze ravnega in za kmetijstvo primernega sveta. Za večino naselij je značilna strnjena gručasta pozidava, saj se tako ohrani največ kmetijskih površin. Vasi so večinoma podolgovate, razpotegnjene, največkrat sta le dva dolga niza hiš. V novejšem času mnoge hiše propadajo, nekatere pa se spreminjajo v počitniške. Prevladujejo enonadstropne stavbe, kjer sta pod isto streho stanovanjski del in hlev za živino. Z nadmorsko višino se zmanjšujeta delež prebivalstva in število naselij, s tem pa tudi povprečna velikost naselij. Brkinska naselja so slabo opremljena s centralnimi dejavnostmi. Le nekatera imajo eno ali dve centralni dejavnosti, največkrat gostilno ali okrepčevalnico in trgovino z živili. Ker je mreža trgovin z živili skromna, je po večini naselij organizirana potujoča trgovina, ki kraje obišče enkrat ali dvakrat tedensko. Za Brkine sta značilni redka naseljenost in močna dnevna migracija. Zaradi pomanjkanja delovnih mest se prebivalci zaposlujejo v občinskih središčih, v obalnih mestih, vse več pa jih dnevno migrira tudi v Ljubljano. Posledica teh dnevnih migracij je, da se naselja spreminjajo v spalna (LAs Krasa in Brkinov, 2016). Tudi Ogrin (2013) poudarja, da imajo Brkini zaradi višine manj sredozemski značaj (pogost vremenski pojav je tam žled), so slabše razviti in se soočajo z demografskimi problemi.

Kras je kamnita pokrajina, zgrajena večinoma iz apnencev in $\mathrm{v}$ manjšem deležu dolomitov. Apnenec je sedimentna kamnina, ki jo sestavlja pretežno kalcijev karbonat. Padavinska, rahlo kisla nasičena voda raztaplja apnenec in zaradi tega prihaja do kraških pojavov tako na površini (škraplje, žlebiči, škavnice, vrtače, uvale itd.) kot tudi pod zemljo (jame in brezna). Kraški oz. apnenčasti del obravnavanega območja sestavljajo planota Kras (to delimo na več enot, in sicer Divaški Kras, Komenski Kras in Senožeško pokrajino) ter Podgorski Kras, Podgrajsko (tudi Matarsko) podolje ter slovenski del zakrasele in planotaste Čičarije, ki se na severozahodu zaključuje z razglednim Slavnikom. V to skupino uvrščamo še Rakitovško-Movraški Kras, Kojniško-žbevniško pogorje ter Izolski Kras, ki je edini kraški predel ob morju, zato ima tudi povsem drugačen značaj kot ostale naštete planote. Podgorski in Rakitovško-Movraški Kras ležita na nadmorski višini okoli 400 do $500 \mathrm{~m}$, pod njima je stopnjasta prehodna pokrajina Bržanija, Slavniško pogorje pa se dviguje od 600 do dobrih 1000 m nadmorske višine. Posebnost je tudi kraški otok oz. območje Stene v spodnjem delu doline Dragonje. Na severu se 


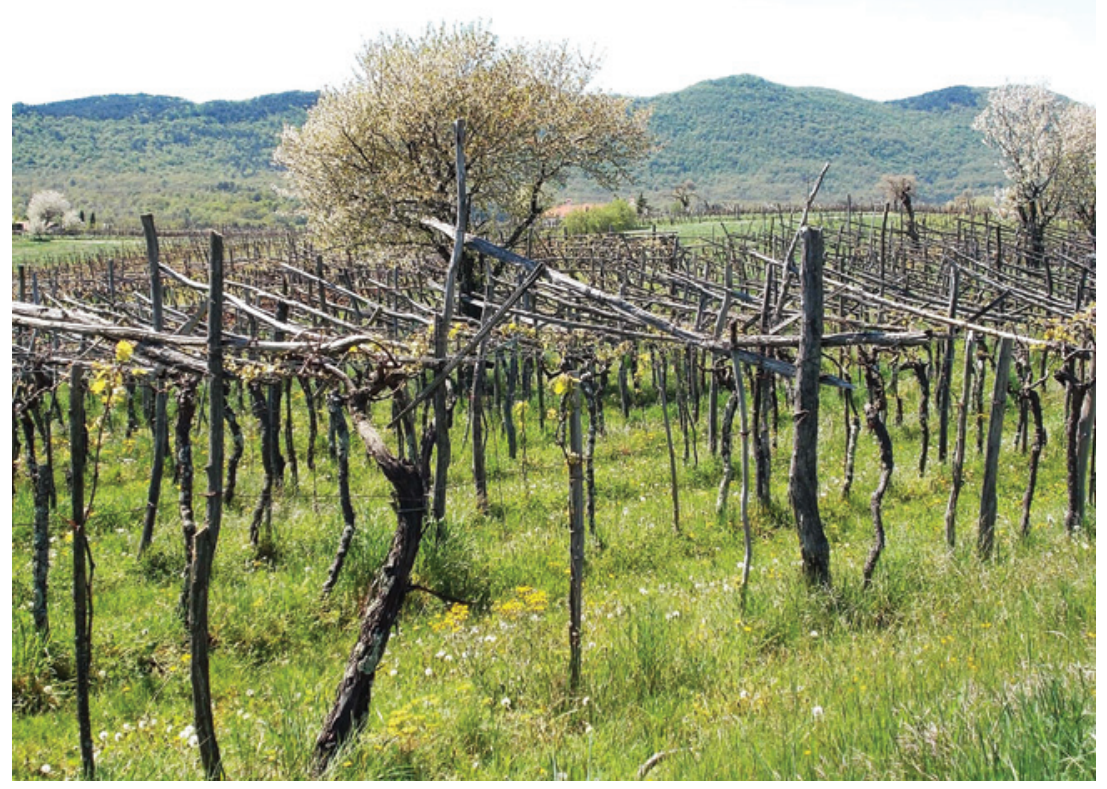

Slika 1.2 Matični Kras pri Tomaju: latniki dajejo pečat kulturni pokrajini, deželi terana (avtor Simon Kerma)

del kraške planote strmo spušča v flišno dolino Branice in Raše, nad katero se proti vzhodu dvigajo odmaknjene Vrhe. Nekoliko južneje proti vzhodu območje zapira več kot tisoč metrov visoka Vremščica. Po planoti Kras, ki je bila v preteklosti zaradi različnih vzrokov - tudi antropogenih - precej kamnita in gola, so znanstveno poimenovali poseben tip površja s kraškimi pojavi, saj so se tu najprej začele sistematične krasoslovne raziskave (Ogrin, 2013).

Danes je Kras že precej poraščen in kulturna pokrajina je precej izpostavljena transformaciji s širjenjem grmovno-gozdnega rastja. Za Kras so značilne strnjene gručaste vasi, zgrajene na prisojnih južnih pobočjih rahlo valovitega sveta. Njihova značilnost so ozke vaške ulice ter kamnite hiše $\mathrm{z}$ majhnimi okni in zunanjimi stopnicami, ki vodijo na pokrit gank (balkon) z leseno ograjo. Borjač (kraško dvorišče) je zaprt s kamnitim zidom, vstop pa je skozi kamnito kaluno, ki je lepo obdelana. Majhna okna in obzidano dvorišče sta prebivalce ščitila pred mrzlo burjo. Na dvoriščih bogatejših kmetij so tudi kamnite štirne (vodnjaki) z vodo (LAs Krasa in Brkinov, 2016; Ogrin, 2013; Rejec Brancelj, 1998; Repolusk, 1998). 


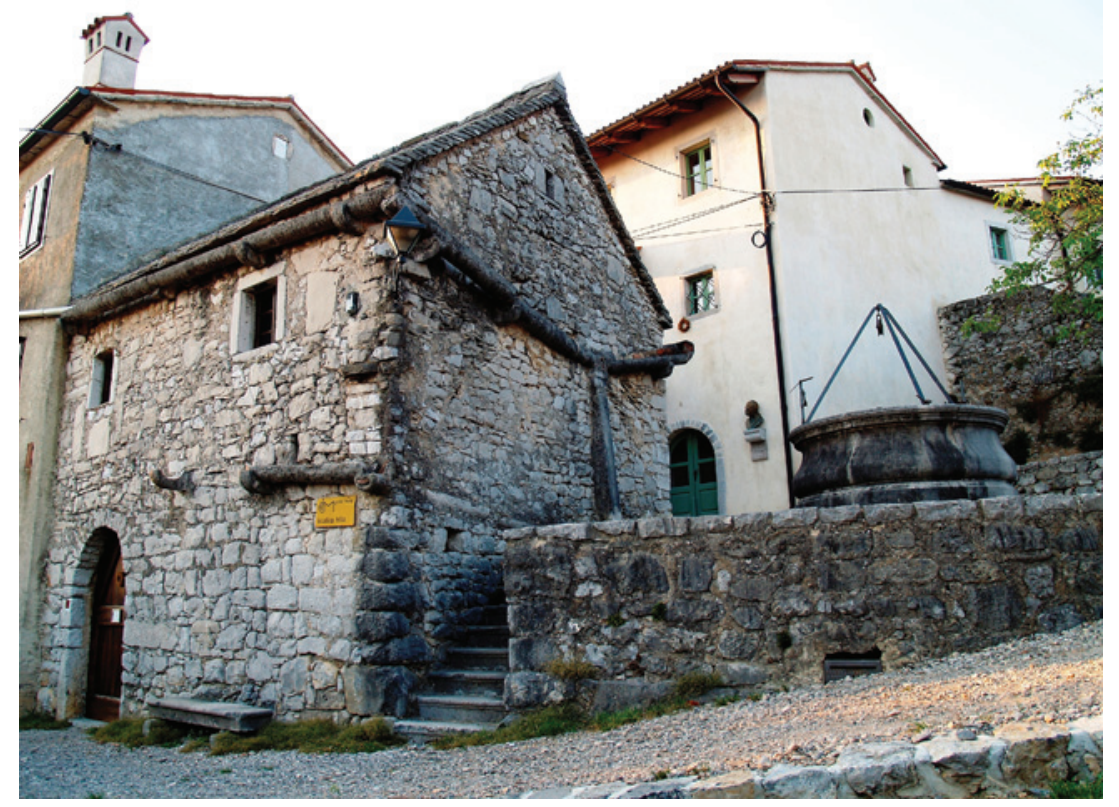

Slika 1.3 Tipična kraška arhitektura v Štanjelu (avtor Simon Kerma)

Za razliko od flišnih pokrajin s površinskim vodnim odtokom, ki v celoti pripada jadranskemu povodju (najpomembnejše reke so Dragonja, Reka in Rižana in imajo značilnosti dežnega ali dežnosnežnega odtočnega režima), ima zakrasela polovica sredozemskega sveta zelo skopo površinsko mrežo vodotokov ali je povsem brez nje (kar velja tako za kraško Istro kot za Kras). Vsa jezera ali jezerca so umetnega nastanka, nastala so z zajezitvijo vodotokov za potrebe namakanja, zadrževanja poplavnih voda ali ustvarjanja zalog pitne vode. Na Krasu in ponekod v Brkinih so v bližini vasi nastali površinsko skromni, a izjemno dragoceni kali in lokve, da so ljudje v sušnih poletjih napajali živino (Repolusk, 1998).

\section{Tržaški zaliv - slovensko okno v svet}

Slovensko morje obsega južni del Tržaškega zaliva, kjer Sredozemsko morje pri Tržiču (Monfalcone) doseže najsevernejšo geografsko širino. Ozemlju Republike Slovenije sicer pripada približno tretjina Tržaškega zaliva (Ogrin, 2013). Izrazita zajedenost severnega Jadrana v srednjeevropsko kopno ter relativna zaprtost in plitvost Tržaškega zaliva s številnimi sladkovodnimi pritoki, ob značilnem prepletanju 
morskih in celinskih dejavnikov, dajejo temu območju poseben pečat in posledično vplivajo tudi na ekološko občutljivost slovenskega morja (Lipej in Kerma, 2012). Slednje je po nastanku (v geološkem smislu) dokaj mlado, saj je bil relativno plitvi severni Jadran še v času zadnje poledenitve $\mathrm{v}$ celoti kopno, medtem ko je morje $\mathrm{v}$ živahnem pliocenu segalo vse do vznožja Alp. Nedavna geotektonika povzroča postopno dviganje zahodne obale Jadrana in sočasno pogrezanje vzhodne obale pod morsko gladino za približno $2 \mathrm{~m} \mathrm{v} 2.000$ letih (Orožen Adamič, 1998). Na postopno dviganje višine morja vplivajo tudi podnebne spremembe, na kar opozarjata naraščajoča linearna trenda srednje letne temperature slovenskega morja in srednje letne temperature zraka ob slovenski obali (Fatorić, 2009).

Zaprt Tržaški zaliv je zaradi skromne razsežnosti (pribl. $9 \mathrm{~km}^{3}$ ) in plitvosti sicer precej izpostavljen velikim nihanjem temperature in slanosti morja, dokaj izraženo pa je tudi plimovanje, ki je v tem delu Jadrana največje in vpliva tudi na prevladujočo smer morskih tokov. Kroženje vode $\mathrm{v}$ Tržaškem zalivu je $\mathrm{v}$ veliki meri povezano $\mathrm{z}$ vzhodnim jadranskim tokom, katerega šibkejši del se pomika ob zahodni obali Istre severno v smeri proti Trstu. Na pogosto menjavanje smeri tokov od sv na Jv ali obratno vpliva tudi trenutna vremenska situacija, zlasti prevladujoči močni vetrovi iz smeri vzhod-severovzhod ter jug in jug-jugozahod (Kolbezen, 1998).

Ob slovenskem morju se razteza jugovzhodni ali istrski del obale Tržaškega zaliva, kjer se izmenjujeta abrazijski in akumulacijski tip obale iz pretežno eocenskega fliša, ki ga pri Izoli prekinja apneniška obala (Orožen Adamič, 1998). Za prvi tip obale so značilni visoki flišni klifi, ki so zaradi težje dostopnosti v veliki meri ohranili svojo naravno podobo, medtem ko je za tip obale, ki se je oblikoval ob izlivih rek in potokov z značilnimi poplavnimi ravnicami, prevladujoče antropogeno preoblikovanje v soline, polja, naselja, marine ipd. Obalna mokrišča so se tako ohranila le v manjši meri, a so ta zaradi izjemne raznolikosti rastlinstva in živalstva med najpomembnejšimi elementi biotske raznovrstnosti slovenske obale (Lipej, Turk in Makovec, 2006).

Morje je tako za obalno-kraško regijo kot državo Slovenijo izjemnega pomena, saj ju uvršča med pomorske dežele in usmerja razvoj (ob)morskih dejavnosti, kot so pomorstvo, obmorski turizem, luški promet, ribištvo in solinarstvo (Ogrin, 2013). Tudi sicer so morje, priobalni del in podeželje zgodovinsko od nekdaj družbeno- 


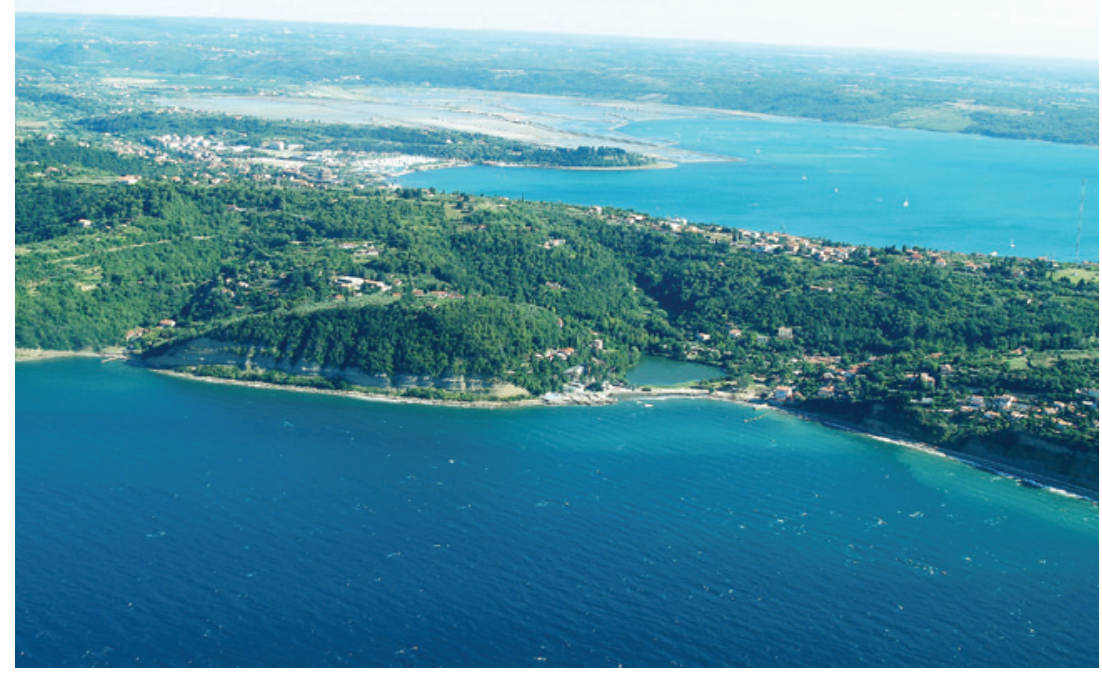

Slika 1.4 Izmenjavanje akumulacijskega in abrazijskega tipa obale ob slovenskem morju (avtor Simon Kerma)

ekonomsko tesno povezani, kar v različnih kontekstih velja še danes. Obravnavana regija ima zelo ugodno geostrateško lego in relativno dobro dostopnost do slovenskih ter čezmejnih oziroma evropskih urbanih in gospodarskih središč (LAs Istre, 2018).

Istrski del obalno-kraške regije lahko razdelimo na obmorski oz. (pri)obalni urbaniziran in gospodarsko razvit pas, kjer so poleg regionalnega središča Koper razmeščena večja naselja Ankaran, Izola, Piran, Portorož in Lucija, potem je tu obmestni ali suburbaniziran pas (ta vključuje zlasti naselja Hrvatini, Spodnje Škofije, Dekani, Bertoki, Prade, Jagodje in Seča) ter gričevnato zaledje oz. podeželje, ki je brez večjega centralnega naselja, in ga tvorijo predvsem mnoga manjša naselja in zaselki. Nekoliko pomembnejšo funkcijo v naselbinski mreži podeželja imajo zlasti naselja Sv. Anton, Gračišče, Marezige in Šmarje. Ločnica med urbanim in ruralnim delom je vse manj jasna in izrazita, saj smo priča procesom (sub)urbanizacije tudi proti notranjosti regije (LAs Istre, 2018). Največje naselje na območju Krasa in Brkinov je Sežana, ki ima status »središče regionalnega pomena«, medtem ko spadajo Divača, Senožeče, Hrpelje, Lokev - Lipica, Dutovlje, Štanjel - Kobdilj - Kobjeglava ter Tomaj - Križ - Šepulje pod »druga urbana območja«, Komen pa spada med »funkcionalna urbana območja«. Prebivalstvo zahodnega dela planote v glavnem 
gravitira k Novi Gorici in Sežani, prebivalstvo Podgorskega krasa in Čičarije pa h Kopru. Območje se nahaja ob meji z Italijo in s Hrvaško ter ima ugodno geografsko lego, kar ponuja številne možnosti čezmejnega sodelovanja (LAs Krasa in Brkinov, 2016).

\section{Naravne vrednote, zavarovana območja in kulturna dediščina}

Celotno območje obalno-kraške regije se ponaša $\mathrm{z}$ bogato naravno in kulturno-zgodovinsko dediščino ter pestrim rastlinskim in živalskim svetom (večji del Krasa in obsežen del Slovenske Istre se uvršča v omrežje Natura 2000). Na območju so različne kategorije posebnih varstvenih in zavarovanih območij narave. Največji obseg v Slovenski Istri predstavljajo ekološko pomembna območja, med katera se uvršča zakraseli del, to so Škocjanski zatok, porečje Dragonje, reka Rižana, Vanganelsko jezero s pritoki, Žusterna, Strunjanske soline s Stjužo, Strunjanski klif, Sečoveljske soline s Sečo, morje in morsko obrežje ter še nekatera druga manjša območja. Posebna zanimivost so tudi geološki pojavi, od sten, udorov, spodmolov do jam, in t.i. apnenčasti otok oziroma Stena pri Dragonji. Med ožja zavarovana območja se uvrščajo trije naravni rezervati (Škocjanski zatok, Strunjanske soline s Stjužo in Strunjan), naravni spomeniki (Slavnik, Debeli rtič, Sv. Nikolaj pri Ankaranu, Žusterna z rastiščem pozejdonke, Jezero v Fiesi in Rt Madona v Piranu) ter obe širši zavarovani območji, Krajinski park Sečoveljske soline in Krajinski park Strunjan (LAS Istre, 2018).

Posebnosti obeh krajinskih parkov sta, da prepletata izjemno naravno in kulturno dediščino, kjer narava in človek sobivata $\mathrm{z}$ roko $\mathrm{v}$ roki, ter da imata oba parka soline, ene zadnjih v Sredozemlju, kjer se sol pridobiva ročno (Sovinc, 2016). Strunjanske soline so celo najsevernejše in najmanjše ohranjene soline v Sredozemlju. Strunjanski park ima tako kopni kot morski naravni rezervat, znan pa je po strmih in prepadnih flišnih stenah Strunjanskega klifa, ki so najvišje na Jadranu (Starman, 2016). Nesojeni krajinski park v marsičem predstavlja edinstvena dolina reke Dragonje, ki se vso svojo pot - od izvira do izliva - izogiba naseljem. Kot zanimiv element kulturne dediščine velja izpostaviti dejstvo, da je v dolini Dragonje nekdaj delovalo približno 40 mlinov (Turk, 2016).

Prav posebno območje varovanja narave na meji med morjem in kopnim v bližini Kopra je Naravni rezervat Škocjanski zatok, ki je edinstven preplet sladkovodnih polslanih in morskih življenjskih 


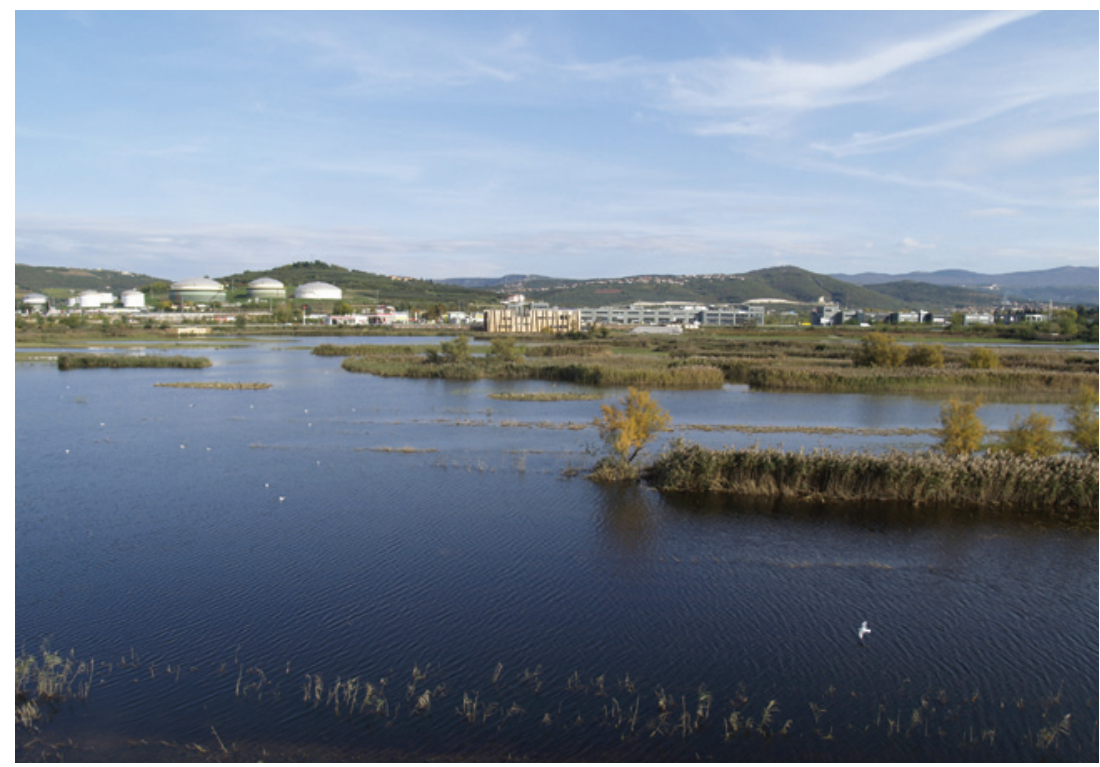

Slika 1.5 Škocjanski zatok je največje polslano mokrišče v Sloveniji (avtor Simon Kerma)

okolij. V zatoku, ki je renaturirano območje sredi urbaniziranega prostora, je bilo v zadnjih nekaj več kot desetih letih zabeleženih več kot 245 vrst ptic, kar je več kot $60 \%$ vseh v Sloveniji opaženih ptic (Šalaja, 2016).

Večji del planote Kras je, kot navedeno, prav tako znotraj območja Natura 2000 (tako po Habitatni direktivi kot po Direktivi o pticah). Tu se pojavljajo številni površinski in podzemeljski kraški pojavi ter evropsko pomembni habitatni tipi (jame, suha travišča, brinje, črničevje, skalne stene itd.). Območje je življenjski prostor evropsko ogroženih živalskih vrst (netopirji, metulji, hrošči, dvoživke) in življenjski prostor evropsko ogroženih vrst ptic (kačar, sršenar, rjavi srakoper, slavec idr.) ter selitveni koridor velikih sesalcev. Ostala, manjša območja, opredeljena kot Natura 2000, so Podgrajsko podolje, dolina Branice, Slavinski ravnik, Reka in Vrhe nad Rašo (LAs Krasa in Brkinov, 2016).

Eno glavnih privlačnosti na Krasu gotovo predstavljajo številne jame, nekatere tudi turistične in odprte za širšo javnost. Jama Vilenica pri Lokvi, ki je dolga okoli $1.300 \mathrm{~m}$, je celo najstarejša turistična jama v Evropi, saj ima registrirane vodene oglede že od leta 1633. Do sredine 19. stoletja je slovela kot najlepša, največja in najbolje obiskana 


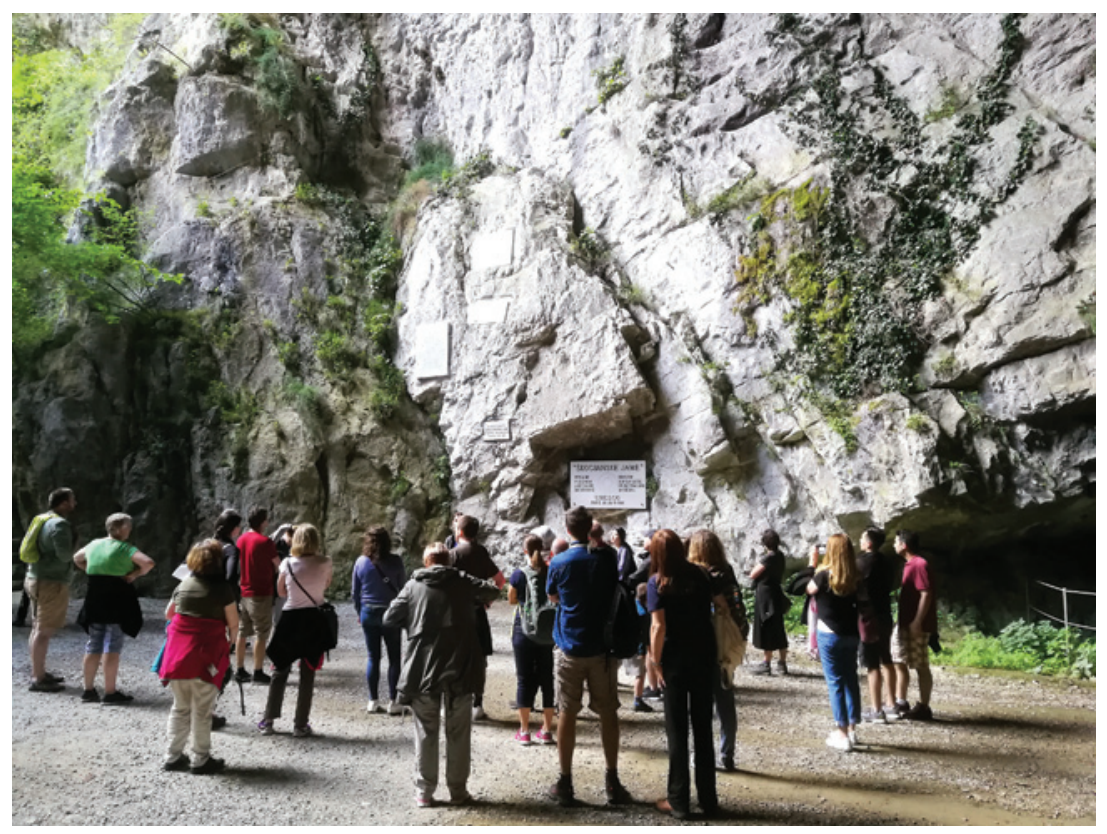

Slika 1.6 Naravni vhod v Škocjanske jame je izhod za turiste (avtor Simon Kerma)

jama matičnega Krasa, ki se danes ponaša z vsakoletno organizacijo Mednarodnega literarnega festivala Vilenica. Potem velja omeniti še Divaško jamo in jamo Dimnice, zelo zanimiva pa je tudi Sveta jama pri Socerbu, ki je hkrati tudi edina podzemna cerkev v Sloveniji, saj so v njej našli številna znamenja in ostanke verskih ceremonij (LAS Krasa in Brkinov, 2016; LAs Istre, 2018).

Od vseh jam, ne samo v regiji, pa po pomembnosti izstopajo Škocjanske jame, po katerih se imenuje tudi širše zavarovano območje - Regijski park Škocjanske jame. Jame so seveda ključni naravni spomenik parka, ki s svojimi razsežnimi dvoranami in pravim podzemnim kanjonom nikogar ne puščajo ravnodušnega. Že od leta 1986 so uvrščene na Seznam svetovne dediščine unesco (Peric, 2016). Park je vključen tudi v Unescov medvladni raziskovalni program Človek in biosfera (MAB), ki združuje biosferna območja po vsem svetu.

Regija se ponaša z bogato kulturno dediščino in tradicijo. Vsebuje nič manj kot 1.807 enot vseh vrst materialne kulturne dediščine, med katerimi je 57 enot nacionalnega pomena (kulturna krajina, terase, stavbe, mlini, sakralni objekti, stara vojaška pokopališča, ohra- 
njena tradicionalna arhitektura - npr. kraški biser Štanjel idr.). Pomembna je tudi nematerialna kulturna dediščina (šege in navade, pesmi, zgodbe, verovanja, praznovanja, tipične jedi, lokalni dialekti itd.), predvsem pa tradicionalna vzreja lipicancev v Kobilarni Lipica, obrtniška veščina gradnje suhozidov (konec novembra vpisana tudi v seznam UNESCO) in tradicionalna proizvodnja morske soli v Sečovljah ter Strunjanu. Obstaja veliko praznikov in festivalov, povezanih s tradicijo, z obredi, s čaščenjem lokalnih svetnikov, karnevali, hrano in $\mathrm{z}$ vinom itd. Bogato ponudbo na področju kulture in kulturne dediščine dopolnjuje široka paleta umetniških galerij, zbirk in muzejev. Eden regionalno pomembnejših je Pokrajinski muzej Koper, medtem ko je v Škrateljnovi domačiji v Divači, rojstnem kraju Ite Rine, Muzej slovenskih filmskih igralcev. Zelo pomemben projekt je tudi Živi muzej Krasa, s katerim želi občina Sežana doseči višjo raven turizma (LAS Krasa in Brkinov, 2016; LAS Istre, 2018).

Leta 2017 je mesto Koper postalo evropska destinacija odličnosti (EDEN) - izbor za področje kulturnega turizma. Mesto, ki je neločljivo povezano s Slovensko Istro, z zelenim zaledjem jadranske obale, je tudi ena od slovenskih zelenih destinacij - Slovenija Green. Evropska destinacija odličnosti 2017 želi biti turistično mesto, zavezano kulturni in okoljski trajnosti. ${ }^{1}$

\section{Socio-ekonomski dejavniki obalno-kraške regije}

\section{Osnovni podatki o obalno-kraški regiji}

Slovenija je razdeljena na 12 statističnih regij: pomursko, podravsko, koroško, savinjsko, zasavsko, posavsko, jugovzhodno Slovenijo (Jv Slovenijo), primorsko-notranjsko, osrednjeslovensko, goriško, gorenjsko in obalno-kraško. Kljub temu, da je majhna država, pa med statističnimi regijami v Sloveniji obstajajo pomembne razlike v gospodarskih značilnostih, ki jih pripisujemo predvsem njihovi legi, infrastrukturi in dostopu do trga dela. Naše preučevanje bo osredotočeno na obalno-kraško regijo, ki je tudi edina statistična regija $\mathrm{v}$ Sloveniji, ki ima izhod na morje. Zaradi naravnih danosti je v regiji še posebej razvit turizem. Turistični sektor ima na tem območju dolgo tradicijo ter razvito turistično infrastrukturo in produkte, promet (Luka Koper) ter gojenje posebnih kultur v kmetijstvu. V tej regiji so naslednje občine: Divača, Hrpelje-Kozina, Izola, Komen, Mestna 
občina Koper, Piran in Sežana ter leta 2011 ustanovljena občina Ankaran. Obalno-kraška regija obsega $1.044 \mathrm{~km}^{2}$, v njej pa je sredi leta 2016 živelo 113.193 prebivalcev. $^{2}$

Po podatkih Statističnega urada Republike Slovenije ${ }^{3}$ je v obalnokraški regiji v letu 2016 živelo nekaj več kot $5 \%$ vseh prebivalcev Slovenije; delež prebivalcev v obalno-kraški regiji je v primerjavi z ostalimi regijami v Sloveniji med nižjimi. V regiji beležijo najvišji delež tujih državljanov med prebivalci (9,7\%) in najvišje število odseljenih prebivalcev v tujino (10 na 1.000 prebivalcev). Po izobrazbeni strukturi je bila skoraj tretjina ( $28 \%$ ) prebivalcev v letu $2016 \mathrm{v}$ starosti od 25 do 64 let $\mathrm{z}$ višješolsko ali visokošolsko izobrazbo. V regiji je bila stopnja brezposelnosti nekoliko višja od slovenskega povprečja (11,8\%). Stopnja registrirane brezposelnosti pri starejših (60+) je bila v letu 2016 najvišja, sledijo pa jim mladi (15-24 let). Med najbolj problematične pa uvrščamo stopnjo dolgotrajne registrirane brezposelnosti, ki nam prikazuje odstotni delež oseb, ki so brezposelne 12 mesec ali več, ter stopnjo zelo dolgotrajne registrirane brezposelnosti, ki nam prikazuje odstotni delež oseb, ki so brezposelne 24 mesecev ali več. Obe stopnji sta v regiji do leta 2015 naraščali, v letu 2016 pa sta ostali na ravni tiste iz leta 2015. $\mathrm{V}$ obalno-kraški regiji sta ti dve ravni med nižjimi v Sloveniji.

V tej regiji je v 2016 nastalo največ komunalnih odpadkov na prebivalca, kar 577 kg. Ločeno zbranih je bilo $57 \%$ vseh odpadkov, medtem ko je slovensko povprečje $67 \%$. Vrednost vseh investicij v varstvo okolja je znašala 2,4\% (Statistični urad Republike Slovenije, 2018).

V regiji beležijo visok BDP na prebivalca, in sicer 19.928 EUR (za leto 2016), višji je bil zabeležen le v osrednjeslovenski statistični regiji. Obalno-kraška regija ima 13.855 delujočih podjetij, povprečno pa so bile v njih zaposlene 3,1 oseba, kar je najmanj v Sloveniji (Statistični urad Republike Slovenije, 2018). Največji delodajalci so naslednja podjetja: Luka Koper, d. d.; Istrabenz turizem, d. d.; Cimos Koper, d.d.; Intereuropa, d.d.; Lama dekani, d. d.; Banka Koper, d.d.; Hoteli Bernardin, d. d.; Splošna bolnišnica Izola; Adriatic-Slovenica, Zavarovalna družba d.d. ${ }^{4}$ Po izgubah in zadolženosti so podjetja $\mathrm{v}$

2. Po podatkih Statističnega urada Republike Slovenije, glej https://www.stat .si/obcine.

3. Glej https://pxweb.stat.si/pxweb/Database/Regije/Regije.asp.

4. Po podatkih Evropske komisije, glej https://ec.europa.eu/eures/main.jsp?lang =sl\&acro=lmi\&catId=2821\&countryId=SI\&regionId=SIo\&langChanged=true. 

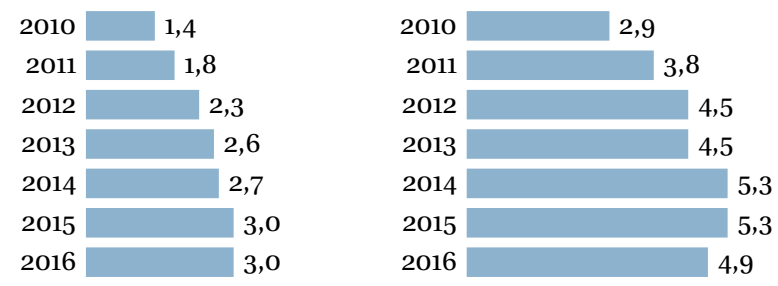

Slika 1.7 Stopnja registrirane zelo dolgotrajne brezposelnosti (levo) ter registrirane dolgotrajne brezposelnosti (desno) v obalno-kraški regiji, v obdobju 2010-2016 (v odstotkih; po podatkih Statističnega urada Republike Slovenije, https://pxweb.stat.si/pxweb/Database/Regije/Regije.asp)

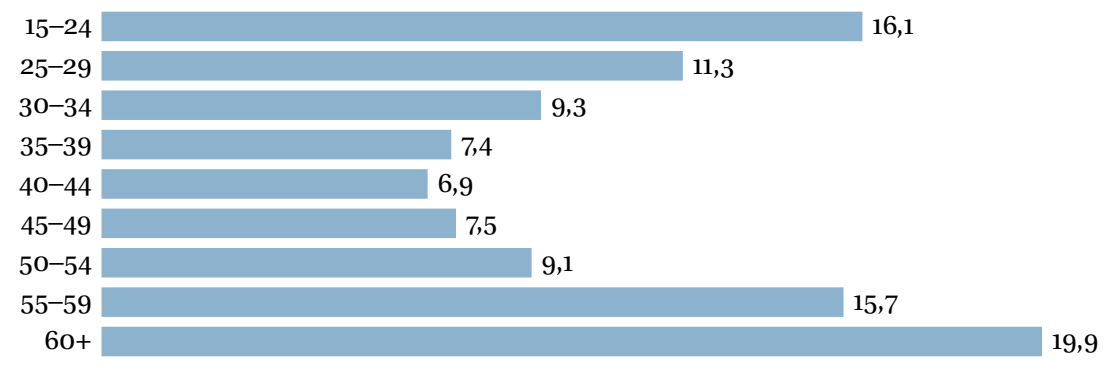

Slika 1.8 Stopnja registrirane brezposelnosti po starostnih skupinah v obalno-kraški regiji, leto 2016 (v odstotkih; po podatkih Statističnega urada Republike Slovenije, https://pxweb.stat.si/pxweb/Database/ Regije/Regije.asp)

regiji nad povprečjem, po letu 2008 je bila izguba delovnih mest velika, posledično je upadla stopnja delovne aktivnosti ter narasla stopnja brezposelnosti (nadpovprečna je v kategoriji starejših, močno pa se je povečala tudi med mladimi).

Povprečna mesečna neto plača je bila v obalno-kraški regiji od slovenskega povprečja nižja za približno 15 EUR in je znašala 1.015 EUR. Prebivalci iz obmejnih regij imajo to možnost, da gredo na delo čez mejo. Zasluženi dohodek pa je v veliko pomoč tistim, ki doma ne dobijo dela, oziroma prebivalcem omogoča, da je njihov zaslužek boljši, kot bi bil doma. Iz obalno-kraške regije tako posamezniki v največjem obsegu hodijo na delo v sosednjo Italijo. Po podatkih uradov za delo v Furlaniji-Julijski krajini je bilo v Italiji zaposlenih konec leta 2014 kar 7.800 Slovencev (Repovž, 2015).

Za Slovenijo je značilna tudi visoka stopnja sive ekonomije, podatki pa kažejo, da se v zadnjih letih ta odstotek sicer nekoliko zmanjšuje $(23,3 \%$ v letu 2015). Na to v največji meri vplivajo ukrepi vlade na 


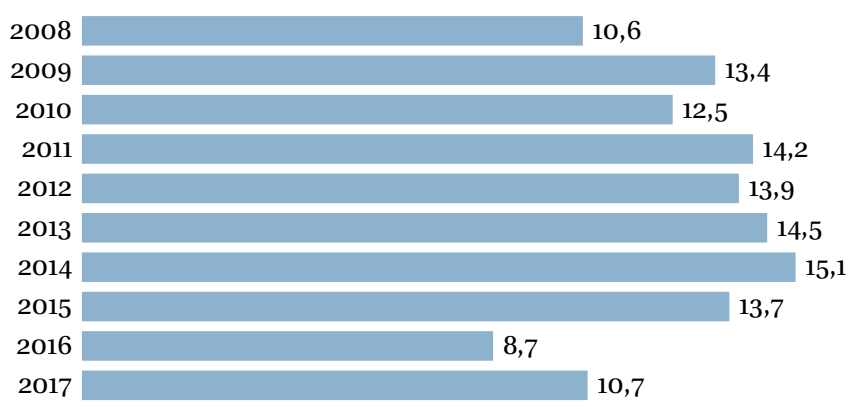

Slika 1.9 Stopnja tveganja revščine (delež oseb v odstotkih), obalno-kraška regija, obdobje 2008-2017 (po podatkih Statističnega urada Republike Slovenije, https://pxweb.stat.si/pxweb/Database/Regije/Regije.asp)

tem področju, vendar pa odstotek še vedno ostaja nad povprečjem EU (Schneider, 2015). Nastav (2009) v svoji raziskavi navaja, da se siva ekonomija v Sloveniji pojavlja predvsem zaradi denarnih koristi, posamezniki v njej vidijo izhod v sili, torej ima socialno noto in v večini primerov služi predvsem za zagotovitev preživetja in ne kopičenje bogastva. Nastav (2009) tudi nakazuje, da je za obalno-kraško regijo značilen nižji odstotek sive ekonomije od povprečja v Sloveniji.

Dohodek uporabljamo tudi za določitev stopnje tveganja revščine. Statistični urad Republike Slovenije (2018) navaja, da je ta izražena kot odstotek oseb, ki živijo v gospodinjstvih z ekvivalentnim razpoložljivim dohodkom, nižjim od praga tveganja revščine, ta pa je opredeljen s $60 \%$ mediane ekvivalentnega razpoložljivega dohodka v državi. V obalno-kraški regiji je v letu 2017 znašala 10,7\% in je bila pod slovenskim povprečjem (13,3\%).

Značilnost obalno-kraške regije je njen izrazito razvit turizem. Ta regija je za slovenski turizem zelo pomembna. V letu 2016 je bilo ustvarjenih skoraj 2,4 milijona nočitev ( $41 \%$ domačih in $59 \%$ tujih turistov), kar regijo postavlja na prvo mesto v državi. Med kraji z največ prenočitvami pa je bil poleg Ljubljane in Bleda ponovno tudi Piran. Kar zadeva narodnost tujih turistov, prevladujejo Italijani, Avstrijci in Nemci (Slovenska turistična organizacija, 2018).

Naravne značilnosti regije poleg turizma omogočajo tudi razvoj prometa in posebnih kmetijskih pridelkov (zlasti grozdja/vina in oljk/oljčnega olja). Kmetijska gospodarstva na tem območju so med najmanjšimi v Sloveniji, ob upoštevanju povprečne kmetijske površine na kmetijsko gospodarstvo in števila živine. Storitve pa ustvarijo 


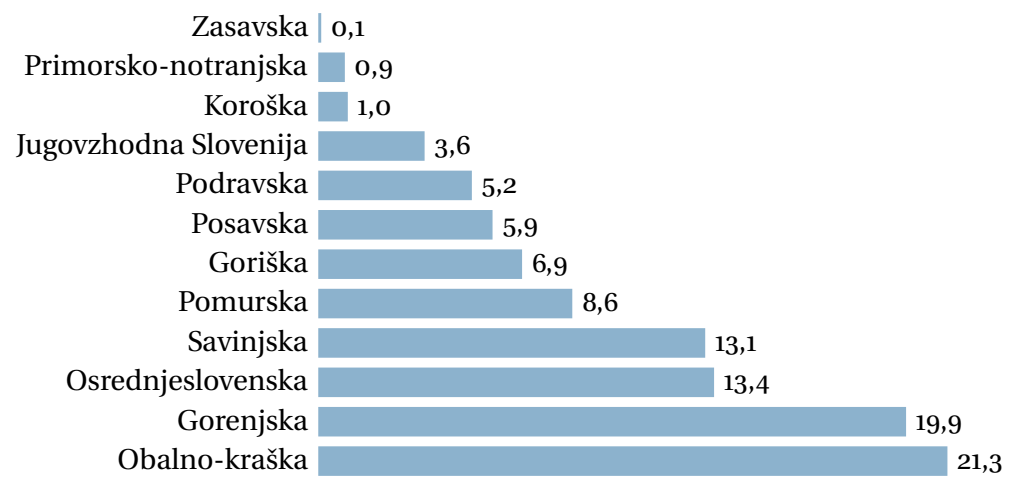

Slika 1.10 Prenočitve turistov po statističnih regijah (v odstotkih, po podatkih Slovenske turistične organizacije, 2017)

kar tri četrtine bruto dodane vrednosti. Med njimi bi izpostavili trgovino, nastanitve in prevozne dejavnosti, ki prispevajo več kot tretjino bruto dodane vrednosti v regiji. Aktivnosti v največji meri nastajajo v koprskem pristanišču, obmorskem ter zdraviliškem turizmu (Statistični urad Republike Slovenije, 2018).

\section{Prometno omrežje}

Prometna dostopnost je dobro razvita, upoštevajoč vsa prometna omrežja. Obala ima s svojo atraktivnostjo veliko vlogo pri privabljanju obiskovalcev. Glavni in najpogostejši način dostopa do območja je cestno omrežje, ki je relativno dobro razpršeno po celotnem območju in v veliki meri poteka brez večjih nevšečnosti, tudi v najvišji sezoni (v juliju in avgustu). Vse ceste so v relativno dobrem stanju. Lokalne ceste, ki so vse povezane z glavnim slovenskim avtocestnim križem, imajo relativno visoko stopnjo dostopnosti z obeh koridorjev (vzhod-zahod in sever-jug). V Sloveniji morajo imeti vsi avtomobili ali druga vozila nalepko za cestnino (vinjeta) za uporabo avtocest in hitrih cest. Predvsem zaradi zelo visokega deleža osebnih avtomobilov je javni cestni potniški promet v Sloveniji zelo slab in v upadu. Javni prevoz je kljub temu relativno dobro organiziran na lokalni ravni, saj povezuje kraje in vasi Slovenske Istre (zaledje) z relativno pogostimi storitvami.

Železniška postaja se nahaja v mestu Koper in povezuje obalni del Slovenije z Ljubljano, glavnim mestom Slovenije, prek omrežja TENт. Uporabnikov potniškega prometa je precej malo; železnica se večinoma uporablja za tovorni promet (Luka Koper). 
Preglednica 1.1 Statistični podatki (zgoraj) in kazalniki (spodaj) obalno-kraške regije

Površina, $\mathrm{km}^{2}, 1.1 .2018$

Število prebivalcev, 1. 7. 2016

113.193

Naravni prirast, 2016

Število študentov, 2016/2017

Število delovno aktivnih prebivalcev, 2016 45.850

Število zaposlenih oseb, 2016 45.043

Število registriranih brezposelnih oseb, 2016

Povprečna mesečna bruto plača, regija prebivališča, 2016

Število podjetij, 2016

Bruto domači proizvod (BDP) v regiji, mio. EUR, 2016

Kmetijska zemljišča v uporabi, ha, 2016

Število prihodov turistov, 2016

Število prenočitev turistov, 2016 2.384 .693

Gostota prebivalstva, preb $/ \mathrm{km}^{2}, 1.7 .2016$ 108

Povprečna starost prebivalcev, leta, 1. 7. 2016

Prebivalci, stari o-14 let, \%, 1. 7. 2016

Prebivalci, stari 65 let ali več, \%, 1. 7. 2016

Skupni prirast, št./1.00o preb., 2016

Prebivalci, stari 15-64 let, brez izobrazbe ali z nepopolno osnovno šolo ali osnovno šolo, \%, 1. 1. 2016

Prebivalci, stari 25-64 let, $\mathrm{z}$ višjo ali visoko izobrazbo, \%, 1. 1. $2016 \quad 27,8$

$\begin{array}{ll}\text { Stopnja registrirane brezposelnosti, \%, } 2016 & 10,1\end{array}$

$\begin{array}{ll}\text { Stopnja delovne aktivnosti, \%, } 2016 & 60,4\end{array}$

Izdana gradbena dovoljenja za stanovanjske stavbe, $2016 \quad 106$ $\begin{array}{lr}\text { BDP na prebivalca, EUR, } 2016 & 19.928\end{array}$

Osebni avtomobili, št./10o preb., 31. 12. 2016

Komunalni odpadki, zbrani z javnim odvozom, kg/preb., $2016 \quad 448$

Opombe Po podatkih Statističnega urada Republike Slovenije (https://www.stat .si/obcine, https://pxweb.stat.si/pxweb/Database/Regije/Regije.asp).

Kar zadeva letalski prevoz, se v najjugozahodnejšem delu Slovenije nahaja mednarodno letališče Portorož. Ima strateško lego, saj je geografsko dobro umeščeno v srednjo Evropo ter ima dobre cestne povezave s središčem države in sosednjimi regijami. Od mondenega Portoroža je oddaljeno zgolj $5 \mathrm{~km}, 15 \mathrm{~km}$ od hrvaškega Umaga in 20 km od italijanskega Trsta. Njegova značilnost je tudi, da ima precej kratko pristajalno pot. Kljub temu pa ima letališče potencial, ki je precej neizkoriščen. Zato so letališča, ki jih večinsko uporabljajo 
prihajajoči obiskovalci in odhajajoči potniki, mednarodno letališče v Trstu v Italiji, mednarodno letališče Ljubljana v Sloveniji ter letališča Benetke in Treviso v Italiji ter Pula na Hrvaškem.

Od leta 2005 ima Koper tudi pomorski potniški terminal. Med ladjarji je dobro poznana destinacija, saj so sprejeli potniške ladje številnih ladjarjev, vsako leto pa se pojavljajo novi. Potniški terminal Koper razpolaga s 420 metri obale za privezovanje potniških ladij. Pristanek ladje v samem mestu in odličen pristaniški servis sta največji konkurenčni prednosti. Obiskovalci se največkrat odpravijo na enodnevne obiske v Koper in oglede turističnih znamenitosti v širšem zaledju. V koprskem pristanišču pa je zgrajen tudi mednarodni potniški terminal za servisiranje potniških ladij. ${ }^{5}$

Večina pomorskega potniškega prometa tako poteka v Kopru. Letho število potnikov je bilo v letu 2017 okoli 100.000 oseb, trend pa še naprej narašča. ${ }^{6}$ Križarke večinoma prihajajo iz italijanskih ali hrvaških pristanišč. Med poletno sezono so zabeleženi tudi nekateri prihodi zasebnih jadrnic in motornih čolnov.

\section{Turistični profil regije}

Slovenska turistična organizacija (2018) navaja, da imamo v Sloveniji več kot 46 tisoč sob z več kot 134 tisoč posteljami. Beležimo skoraj 5 milijonov prihodov turistov, več kot 12,5 milijona nočitev ter povprečno trajanje bivanja 2,5 noči (podatki za leto 2017). Velik porast se odraža tudi v gospodarskih kazalnikih, turizem je v letu $2017 \mathrm{k}$ slovenskemu bruto domačem proizvodu prispeval 11,9\% in zaposloval 56.014, kar predstavlja 6,5\% delovno aktivnih prebivalcev. Samo v obalno-kraški regiji razpoložljive sobe in postelje predstavljajo $21 \%$ in $20 \%$ nacionalnih zneskov. V letu 2017 je imela regija 885 tisoč prihodov turistov (18\%) in prenočitve skoraj 2,65 milijona prebivalcev, kar predstavlja $21 \%$ zabeleženih nočitev na državni ravni, s povprečno dolžino bivanja 2,99 prenočitve. Obalno-kraška regija je leta 2017 beležila 2.538 nočitev na $\mathrm{km}^{2}$ (2.650.00o nočitev/1.044 km²) (povprečje EU-28 je bilo leta 2015 približno 600 nočitev $/ \mathrm{km}^{2}$ ). Slovenska turistična industrija je ustvarila 2,2 milijarde EUR, od tega je dodana vrednost 1,2 milijarde EUR predstavljala 3,7\% dodane vrednosti ce-

5. Glej https://luka-kp.si/slo/terminali-191/single/potniski-terminal-255.

6. Glej https://pxweb.stat.si/pxweb/Database/Ekonomsko/22_transport/04_22194 _pomorski_transport/04_22194_pomorski_transport.asp. 
lotnega slovenskega gospodarstva. Neposredni turistični BDP v letu 2017 je znašal 2,43 milijarde tolarjev, kar je predstavljalo 11,9\% celotnega вDP Slovenije.

\section{Značilnosti turizma in nadaljnje težnje}

Turistične značilnosti in tendence razvoja turizma v regiji bi morale biti usklajene s Strategijo trajnostne rasti slovenskega turizma 20172021. Strateška vizija ostaja enaka (Ministrstvo za gospodarski razvoj in tehnologijo, 2017, str. 28): „Slovenija je globalna zelena butična destinacija za zahtevnega obiskovalca, ki išče raznolika in aktivna doživetja, mir in osebne koristi.« Slovenija je razdeljena na naslednje turistične makro destinacije: Alpsko Slovenijo, Mediteransko Slovenijo, Termalno Panonsko Slovenijo, Osrednjo Slovenijo in Ljubljano.

Obalno-kraška regija je sestavni del makro destinacije Mediteranska Slovenija. Značilnosti slednje so krajinska raznolikost, kraška naravna čudesa, privlačna in zlahka dostopna mediteranska mesta, tesno povezana z zelenim istrskim podeželjem, podzemna doživetja svetovnega formata, $\mathrm{v}$ simbiozi s kulinaričnimi dobrotami in $\mathrm{z}$ vrhunskimi vini.

Ključni produkti so (Ministrstvo za gospodarski razvoj in tehnologijo, 2017, str. 40):

- poslovna srečanja in dogodki (celoletni poslovni turizem - poslovni gostje na konferencah, srečanjih, motivacijskih srečanjih in razstavah, skupaj s podpornimi dogodki, ki privabijo večdnevne goste);

- zdravje in dobro počutje (celoletni produkt, ki se osredotoča na wellness, sprostitev, preventivo, $\mathrm{z}$ uporabo naravnih zdravilnih dejavnikov in sredozemskega podnebja itd.);

- sonce in morje (tradicionalni sezonski sredozemski produkt, osnovan na promociji plaž, sonca, plavanja, sprostitve, zabave in ostalih aktivnosti);

- gastronomija (kombinacija kulinarične dediščine in sodobnih rešitev, ki odražajo številne lastnosti t. i. sredozemske prehrane, prepletene z alpsko in mednarodno kulinariko, v kombinaciji z vrhunskimi vini).

Sekundarni oziroma podporni produkti pa so: igre na srečo (igralnice), zunanja doživetja v naravi, kulturni, mestni in podeželski turizem, križarjenje in jadranje. 
Preglednica 1.2 Bruto dodana vrednost, obalno-kraška, za trgovino, gostinstvo, promet

\begin{tabular}{lrrr}
\hline Postavka & 2014 & 2015 & 2016 \\
\hline Delež po regijah (Slovenija = 100 \%) & 9,8 & 9,9 & 10,2 \\
Delež po dejavnostih (\%) & 36,8 & 36,3 & 37,0 \\
\hline
\end{tabular}

Opombe Po podatkih Statističnega urada Republike Slovenije (https://pxweb.stat .si/pxweb/Database/Regije/Regije.asp).

\section{Strateške politike $v$ povezavi s turizmom}

Ključne razvojne potenciale regije predstavljajo geostrateška lega v povezavi s koprskim trgovskim pristaniščem in z napovedmi prihodnjih blagovnih tokov ter razvojem turistične ponudbe. V Regionalnem razvojnem programu za južno primorsko regijo 2014-2020 (Regionalni razvojni center Koper in Razvojni svet južnoprimorske regije, 2015) navajajo pet strateških razvojnih ciljev regije. Prvi je konkurenčna regija, ki bo dosežena $\mathrm{z}$ višjo konkurenčnostjo ključnih sektorjev v regiji, med njimi igrata pomembno vlogo krepitev konkurenčnosti turizma (naravni in kulturni turizem, športni turizem, gostinstvo) ter tudi transportno-logistični sektor. Rezultat tega pa bo višja bruto dodana vrednost na zaposlenega v regiji (preglednica 1.2).

V obalno-kraški regiji naj bo turizem prepoznaven po integriranih in s tematskih turističnih izdelkih, ki vključujejo naravne in kulturne posebnosti, znanih blagovnih znamkah ter s pomembnem poudarku na zelenem in kulturnem turizmu. V okviru tega cilja bo en od ukrepov usmerjen k vzpostavitvi centrov znanja, tako na področju logistike, turizma in kmetijstva ter podeželja kot tudi zdravstvene preventive, obnovljivih virov in zdravega bivanjskega okolja. Ustvarjanje novih delovnih mest želijo doseči s krepitvijo in z vzpodbujanjem podjetništva, boljše pogoje pa bodo dosegli tudi z neposrednimi tujimi investicijami. Ukrepi za razvoj turizma bodo usmerjeni v tesnejše sodelovanje akterjev ter vključevanje kulturne in naravne dediščine. Kot drugi cilj poudarjajo pomembnost ustvarjalne in inovativne regije. Razvoj regije bo podpiral centre znanja. Vzpostavili bodo sodelovanje med znanstveno-raziskovalnimi ustanovami, univerzami in gospodarstvom, sodelovanje med podjetji (grozdenje) in njihovimi združenji, ki lahko pomembno vplivajo tudi na turizem. V okolju prijaznem, vključujočem regijskem programu pomemben del predstavljajo krepitev različnih oblik storitev za otroke, mlade, invalide, starejše in programi na področju zdravja ter kulture. Vse to 
lahko pomembno prispeva $\mathrm{h}$ krepitvi turizma v regiji z učinki na različne skupine prebivalstva, kar so poudarili v tretjem cilju, poimenovanem ljudem prijazna, vključujoča regija. Četrti cilj bo osredotočen na razvoj podeželskih območij in trajnostno upravljanje naravnih ter kulturnih dobrin. Regija bo okrepila proizvodnjo visokokakovostne hrane, vključno z morsko hrano (ribištvo, marikultura, solinarstvo) $z$ večjo vlogo znanja in s širšim povezovanjem proizvajalcev. Poudarek je na kakovostni, v sami regiji pridelani hrani, kar bo imelo tudi pomembno vlogo pri razvoju turizma ter kakovosti življenja njenih prebivalcev. Razvoj podeželja bo vključeval ukrepe za varstvo in razvoj kulturne dediščine, ohranjanje narave in biotske raznovrstnosti. Zadnji cilj je povezan s trajnostnim upravljanjem z energijo, okoljem in s prostorom. Prav tako bi lahko del programa, ki vključuje izboljšanje prostorskega načrtovanja in upravljanja prostora ter krepitev mestnega potenciala s sodelovanjem s sosednjimi mesti, vplival na turistične objekte.

\section{Inovativne tehnologije, sistemi in aplikacije}

Regija je izrazito usmerjena v izvajanje strategije pametne specializacije (sps). V Regionalnem razvojnem programu (Regionalni razvojni center Koper in Razvojni svet južnoprimorske regije, 2015) poudarjajo, da bodo še nadalje krepili zmogljivosti in vzpostavili ter okrepili infrastrukturo za ustvarjalno uporabo znanja. Podprli bodo učinkovitost podjetniških vlaganj v raziskave, razvoj in inovacije, ki bodo usmerjene $\mathrm{v}$ celovite rešitve, in sicer od ponudbe proizvodov/storitev do netehnoloških vsebin, kamor spadajo poslovni modeli, organizacijske in procesne inovacije, oblikovanje.

Regija je inovacijsko in tehnološko med naprednejšimi, saj je uveljavila že vrsto najsodobnejših mobilnih aplikacij, med katerimi naj omenimo:

- Mobilne aplikacije s kolesarskimi potmi. S sloganom »Vzdolž ozkih podeželskih poti med živo pisanimi vinogradi ali na krilih obmorske sapice po razgibanih obalnih poteh - raziščite lepote Slovenske Istre s pomočjo priročne mobilne aplikacije, ki vas bo na vsakem koraku usmerjala, predstavila zanimivosti izbranega okoliša ter ponudila odlično izhodišče za nadaljnje raziskovanje. Znani kraji in male zaledne vasice skrivajo marsikateri biser, ki vam bo vzel sapo in pognal po poteh novega navdiha.« na 
spletni strani Portoroža in Pirana vabijo, da si naložimo aplikacijo s kolesarskimi potmi ter dodatno ponujajo še namestitve in doživetja za kolesarje. ${ }^{7}$

- Odkrivanje legend Pirana. Legende Pirana lahko obiskovalci odkrivajo s pomočjo mobilne aplikacije Nexto, ki jih postavi v vlogo aktivnih raziskovalcev Pirana. Obiskovalci lahko na različnih lokacijah odkrivajo znamenitosti, spoznavajo zgodovinske like, rešujejo uganke in se s pomočjo obogatene resničnosti zazrejo v preteklost. V kolikor rešijo vse izzive, jih v Turističnoinformacijski pisarni v Piranu čaka majhna pozornost. Aplikacija je na voljo v štirih jezikovnih različicah. ${ }^{8}$

- Mediadom Pyrhani. Kulturni center in multimedijski muzej v Piranu s pomočjo najsodobnejše tehnologije omogočata spoznavanje zgodovine in kulturnega razvoja mesta. S pomočjo IKT-tehnologije še tako oddaljena preteklost lahko postane zanimiva. Prikazujejo jo v jedrnatih tekstih in odlično zasnovanih filmih - animacijah. Stoletja, v katerih so nastajale soline in se je razvijalo strnjeno ribiško mesto, obdano $\mathrm{z}$ mogočnim obzidjem, so predstavljena $\mathrm{v}$ dveh odlično animiranih filmih $\mathrm{s}$ kratkimi dokumentarnimi posnetki in v privlačnem filmu v 3Dtehniki. Posnetki prikazujejo najimenitnejše osebnosti mesta, arheološka odkritja, sramotilni steber ter predstavljajo najzanimivejše vsebine kulturnih ustanov, tradicionalne prireditve in kulturne dogodke v mestu. ${ }^{9}$

- Aplikacija E-turizem. Aplikacija deluje na način, da uporabnik na pametni telefon naloži aplikacijo e-Turist, vnese svoja zanimanja, čas, ki ga ima na voljo, ter prevozno sredstvo, sistem pa pripravi predlog ogledov, prilagojen njegovim zahtevam. Aplikacija nato uporabnika s pomočjo GPS-navigacije vodi od točke do točke. ${ }^{10}$

- Aplikacija ikras. Aplikacija omogoča odkrivanje Krasa, in sicer iskanje restavracij, muzejev, turističnih kmetij ali zanimivih točk na Krasu na zelo preprost način. Kraji se lahko obiščejo

7. Glej https://www.portoroz.si/si/dozivi/aktivnosti/kolesarjenje/interaktivne -aplikacije.

8. Glej https://www.portoroz.si/si/dozivi/kulturne-znamenitosti/legende-pirana.

9. Glej http://www.mediadom-piran.si.

10. Glej http://www.e-turist.si. 
peš, z avtom ali javnim prevozom, lahko se izbira med različnimi turističnimi potmi. Aplikacija je na voljo za pametne telefone iPhone in Android. ${ }^{11}$

- Aplikacija APP СКšP. Aplikacija obvešča uporabnike o vseh dogodkih, ki jih organizira Center za kulturo šport in prireditve Izola. $^{12}$

- Aplikacija Рмк dogodki. Pokrajinski muzej Koper obvešča uporabnike o dogodkih Muzeja Koper. ${ }^{13}$

Poleg tega je več obalnih mest uvedlo uporabo (najem) električnih vozil in polnilnih postaj za električne avtomobile. Obstajajo tudi drugi inovativni pristopi, ki so povezani z zmanjševanjem prometa, npr., mesto Piran je uvedlo enotno mestno izkaznico za mestni promet, v skoraj vseh mestih obstaja možnost plačila parkirnine s sporočilom sms itd. Naj omenimo še projekt Tehnološki center in platforma za razvoj pametnega okolja (angl. smart community). Projekt se bo vezal na vse ostale projekte v regiji, ki so kompatibilni s konceptom pametnega okolja (Slovenski inštitut tehnologij, demo center za japonske partnerje, center energetike, mobilnost idr.), predvsem pa na razvojne plane občin ter Luke Koper. Koncept "pametnega okolja " predvideva, da je neko okolje dovolj tehnološko razvito, da lahko pametno vodi ter planira posamezne funkcije delovanja v skupnosti (promet, poraba energije, vode pa tudi intervencije ob nesrečah, zdravstvo idr.). Kolikor je mogoče, so odzivi na spremembe avtomatizirani ali vsaj centralno vodeni. Vse odločitve slonijo na realnih podatkih, ki jih v centre odločanja pošiljajo posamezni pametni podsklopi (npr. števci za vodo, porabo elektrike, zasedenosti parkirišč, prihodov avtobusov) (Regionalni razvojni center Koper in Razvojni svet južnoprimorske regije, 2015).

\section{Potencialne možnosti za lokalna podjetja}

Celotna regija si prizadeva za večjo integracijo. To je mogoče doseči z ustanovitvijo novih centrov znanja (na različnih področjih; logistike, turizma in kmetijstva - podeželja ter zdravstvene preventive, ob-

11. Glej https://www.slovenia.info/sl/novinarsko-sredisce/novice/1423-ikras -nova-aplikacija-za-odkrivanje-krasa.

12. Glej http://center-izola.si/o-nas/predstavitev/aplikacija.

13. Glej https://www.pokrajinskimuzejkoper.si/si/aktualno/nova-brezplacna -aplikacija-vas-obvesca-o-muzejskih-dogodkih. 
novljivih virov in zdravega bivanjskega okolja), ki so tudi eden najpomembnejših strateških ciljev oziroma prednostnih nalog regije. Vzpostavljeno je bilo sodelovanje med znanstveno-raziskovalnimi ustanovami, univerzami in podjetji, sodelovanje med podjetji in njihovimi združenji, s ciljem okrepiti regijo, da postane bolj podjetniška in samozavestnejša predvsem v smislu priprave dokumentacije, načrtovanja in upravljanja. Poleg tega bo v okviru evropskega združenja za teritorialno sodelovanje (EzTs) vzpostavljena trajnejša struktura sodelovanja med obalnimi mesti in zaledjem. Mesta v regiji so majhna, s skromnimi mestnimi potenciali. To je lahko ovira za razvoj, saj mesta ali njihova omrežja najpogosteje postanejo ključni razvojni generatorji in privabljajo temeljne (pred)razvojne dejavnike ter vlagatelje. Poleg tega imajo mesta pomembno vlogo v gospodarstvu kot središče povezav, inovacij, ustvarjalnosti in storitev. Sodelovanje mest $\mathrm{v}$ trajnostni urbani agendi, ki bo usklajeno na regionalni in čezmejni ravni, bo poskušalo preseči te omejitve, izboljšati dostop do razpoložljivih virov EU, okrepiti sinergije, zmanjšati stroške iz ekonomije obsega in povečati prepoznavnost na širšem območju EU. Načrtuje se tudi integrirano upravljanje z ožjim obalnim pasom, na katerem so omejeni ključni proizvodi in potenciali regije (narava in biotska raznovrstnost, krajina, kulturna dediščina, gospodarski, turistični, rekreativni potenciali itd.) (Regionalni razvojni center Koper in Razvojni svet južnoprimorske regije, 2015).

\section{Zaključek}

Naj zaključimo z vizijo razvoja regije, ki je za obdobje 2014-2020 opredeljena $v$ regionalnem razvojnem programu (Regionalni razvojni center Koper in Razvojni svet južnoprimorske regije, 2015, str. 4) in se glasi: »Južna Primorska - Evropsko okno v svet. Regija uspešnega gospodarstva visoke kakovosti bivanja na temelju ustvarjalnosti ljudi in trajnostnega gospodarjenja $\mathrm{z}$ dobrinami."

Za dosego te vizije bo v obalno-kraški regiji potrebno predvsem povečati zaposlenost ter zmanjšati število ljudi, ki jim grozita revščina in socialna izključenost, ustaviti usihanje družbenih storitev, ki so ključnega pomena za kakovost življenja, in krepitev trajnostnih vzorcev proizvodnje, potrošnje in prostorske organizacije v regiji. Regija ima možnosti izkoriščanja obmorske lege in morja (Evropsko okno v svet), njen nadaljnji razvoj pa lahko v veliki meri temelji tudi na "pristanišču, kot vozlišču logističnih, transportnih in blagovnih po- 
vezav ter storitev, pa tudi na trajnostnem razvoju turizma v priobalnem in zalednem Krasu kot pomembnemu elementu vključevanja regije v svet « (Regionalni razvojni center Koper in Razvojni svet južnoprimorske regije, 2015, str. 4). Prav turizem je zaradi naravnih danosti, ugodne lege in dostopnosti ena ključnih gospodarskih panog na obravnavanem območju. Še vedno je razvit predvsem v obalnem delu, medtem ko je na podeželju še v razvojni fazi in mnogi potenciali podeželja za razvoj turizma (še) niso izkoriščeni, kot bi lahko bili. Raznovrstnost ponudbe se mora tako usmeriti v podeželski 3Eturizem (ekološki, etnološki in enološki), rekreativni 3A-turizem (aktivni, akcijski in adrenalinski) ter 3D-turizem (doživljajski, dediščinski in domišljijski). Z razvojem takšne ponudbe bi dosegali boljšo celoletno razporeditev gostov z namenom ublažiti masovni sezonski turizem in ponuditi alternativne možnosti za celoletni zeleni turizem. Potrebno je ustvariti unikaten regionalni proizvod z imidžem, ki pritegne obiskovalca in mu zagotovi edinstveno ter avtentično doživetje.

Regija ima tako glede na zapisane značilnosti in možnosti še veliko potenciala za nadaljnji razvoj ter tudi raziskave. Potrebno je poiskati povezave med različnimi sektorji in ponudniki ne le v sklopu turizma, pač pa tudi v segmentih kmetijstva, storitvenih dejavnosti, obrti in trgovine, pomorstva in ribištva ter zlasti izobraževanja (LAS Istre, 2018). Eden izmed pomembnejših ciljev strategije razvoja regije v prihodnosti je vsekakor krepitev dejavnosti raziskav, razvoja in inovacij (RRI), na področjih, kjer ima regija kompetence in kapacitete, ob večji vlogi univerz ter v povezavi s ključnimi družbenimi, okoljskimi in tržnimi izzivi.

\section{Literatura}

Fatorić, S. (2009). Spreminjanje višine morja v severnem Jadranu kot pokazatelj podnebnih sprememb. Geografski vestnik, 81(1), 9-21.

Kolbezen, M. (1998). Hidrografija. V I. Gams in I. Vrišer (ur.), Geografija Slovenije (str. 139-172). Ljubljana: Slovenska matica.

LAS Istre. (2018). Strategija lokalnega razvoja LAS Istre 2014-2020. Pridobljeno s http://www.las-istre.si/files/pages/112

LAS Krasa in Brkinov. (2016). Strategija lokalnega razvoja za Lokalno akcijsko skupino Krasa in Brkinov. Pridobljeno s https://www .laskrasainbrkinov.si/wp-content/uploads/2016/11/SLR-2014-2020 .pdf

Lipej, L., in Kerma, S. (2012). Stanje in ogroženost biodiverzitete sloven- 
skega morja. V D. Ogrin (ur.), Geografija stika Slovenske Istre in Tržaškega zaliva (str. 159-176). Ljubljana: Znanstvena založba Filozofske fakultete.

Lipej, L., Turk, R., in Makovec, T. (2006). Ogrožene vrste in habitatni tipi v slovenskem morju. Ljubljana: Zavod Republike Slovenije za varstvo narave.

Ministrstvo za gospodarski razvoj in tehnologijo. (2017). Strategija trajnostne rasti slovenskega turizma 2017-2021. Pridobljeno s http:// www.mgrt.gov.si/fileadmin/mgrt.gov.si/pageuploads/Strategija _turizem_koncno_5.10.2017.pdf

Nastav, B. (2009). Prikrita proizvodnja: siva ekonomija $v$ Sloveniji. Koper: Fakulteta za management.

Ogrin, D., in Plut, D. (2009). Aplikativna fizična geografija Slovenije. Ljubljana: Znanstvena založba Filozofske fakultete.

Ogrin, D. (2013). Slovenske pokrajine na stiku in prehodu. V Veliki atlas Slovenije (str. 18-35). Ljubljana: Mladinska knjiga.

Orožen Adamič, M. (1998). Tržaški zaliv. V D. Perko in M. Orožen Adamič (ur.), Slovenija: pokrajine in ljudje (str. 282-291). Ljubljana: Mladinska knjiga.

Peric, B. (2016). Regijski park Škocjanske jame. V Naravni parki Slovenije (str. 65-69). Nazarje: GEAart.

Perko, D., in Kladnik, D. (1998). Zgodovina regionalizacij Slovenije. V D. Perko in M. Orožen Adamič (ur.), Slovenija: pokrajine in ljudje (str. 20-31). Ljubljana: Mladinska knjiga.

Regionalni razvojni center Koper in Razvojni svet južnoprimorske regije. (2015). Povzetek Regionalnega razvojnega programa za južno primorsko regijo. Pridobljeno s https://www.rrc-kp.si/images/stories/ dokumenti/RRP/Povzetek_RRP_kon\%C4\%8Dni.pdf

Rejec Brancelj, I. (1998). Kras. V D. Perko in M. Orožen Adamič (ur.), Slovenija: pokrajine in ljudje (str. 234-244). Ljubljana: Mladinska knjiga.

Repolusk, P. (1998). Sredozemski svet. V D. Perko in M. Orožen Adamič (ur.), Slovenija: pokrajine in ljudje (str. 194-207). Ljubljana: Mladinska knjiga.

Repovž, E. (2015, 4. junij). Brezposelnost na Primorskem zmanjšujejo delovni migranti v Italijo. Pridobljeno s http://www.delo.si/ gospodarstvo/trg-dela/brezposelnost-na-primorskem-zmanjsujejo -delovni-migranti-v-italijo.html

Schneider, F. (2015). Size and development of the shadow economy of 31 European and 5 other OECD countries from 2003 to 2015: Different developments. Pridobljeno s http://www.econ.jku.at/members/ Schneider/files/publications/2015/ShadEcEurope31.pdf

Slovenska turistična organizacija. (2017). Turizem $v$ številkah. Ljubljana: Slovenska turistična organizacija. 
Slovenska turistična organizacija. (2018). Turizem v številkah. Ljubljana: Slovenska turistična organizacija.

Sovinc, A. (2016). Krajinski park Sečoveljske soline. V Naravni parki Slovenije (str. 103-105). Nazarje: GEAart.

Starman, M. (2016). Krajinski park Strunjan. V Naravni parki Slovenije (str. 109-111). Nazarje: GEAart.

Statistični urad Republike Slovenije. (2018). Regije v številkah - statistični portret slovenskih regij 2018. Pridobljeno s https://www.stat.si/ StatWeb/File/DocSysFile/8141

Šalaja, N. (2016). Naravni rezervat Škocjanski zatok. V Naravni parki Slovenije (str. 115-117). Nazarje: GEAart.

Turk, R. (2016). Dolina Dragonje. V Naravni parki Slovenije (str. 232-233). Nazarje: GEAart. 


\section{Trajnostno upravljanje z destinacijo:}

\section{oblikovanje certifikacijske sheme}

\section{za območje Mediteranske Slovenije}

\section{Marko Kukanja}

Turizem je najhitreje rastoča gospodarska panoga in predstavlja gonilo gospodarskega razvoja. $Z$ razvojem pa turizem prinaša pritiske na naravno, kulturno in družbeno okolje. Posledično se je družbeno razumevanje turizma v zadnjih desetletjih spremenilo. Na pomenu je pridobila paradigma trajnostnega razvoja, ki predstavlja osnovo bodočega turističnega razvoja - tako na globalni kot regionalni ravni. Tudi Slovenija se je zavezala k razvoju trajnostnega turizma. Vzpostavila je institucionalni okvir, ki podpira prizadevanje pristojnih državnih organov in turističnih ponudnikov za trajnostni razvoj turističnih destinacij in produktov. Slovenska turistična organizacija (sTo) je leta $2014 \mathrm{z}$ akreditiranim partnerjem mednarodne organizacije Green Destination v Sloveniji, Tovarno trajnostnega turizma Goodplace, ${ }^{1}$ razvila nacionalni program trajnostnega razvoja turizma $\mathrm{v}$ Sloveniji, imenovan Zelena shema slovenskega turizma (zsst), ki se trži pod blagovno znamko Slovenia Green.

Na območju destinacije Mediteranska Slovenija so trenutno v shemo vključeni zgolj destinacija Koper ter nekaj zasebnih ponudnikov (tradicionalne hiške slovenske Istre). Brez tovrstnih ponudnikov destinacija težko gradi verodostojen trajnostni turistični razvoj. Ker se za odločitev v shemo odloča relativno malo ponudnikov, je osrednji

1. Glej www.lab-goodplace.com/trajnostni-turizem. 
namen pričujočega prispevka predstaviti postopek oblikovanja nove, prilagojene certifikacijske sheme za Mediteransko Slovenijo. Pri tem se, upoštevajoč nekatere specifike območja, naslanjamo na konceptualni okvir zsst ter pomembnejše mednarodne okoljske znake.

Uporabljen metodološki pristop je prvenstveno kvalitativen, saj smo v prispevku predstavili koncept trajnostnega turizma, različne modele in indikatorje trajnostnega razvoja v turizmu, certifikacijske sheme in znake, izpostavili smo zsst ter podali predlog za oblikovanje nove sheme. Nov, poenostavljen pristop ne predstavlja konkurence obstoječemu nacionalnemu certifikacijskemu programu zsst, temveč ga, v smislu implementacije trajnostnih načel in aktivnosti na specifičnem geografskem območju, smiselno dopolnjuje. Na ta način želimo predvsem spodbuditi nadaljnji trajnostni razvoj destinacije, dolgoročni cilj pa predstavlja vključitev čim večjega števila deležnikov v zssT.

\section{Opredelitev trajnostnega turizma}

Turizem je tako v svetu kot v Sloveniji najhitreje rastoča gospodarska panoga, v številnih regijah pa predstavlja temelj gospodarskega razvoja. Z razvojem pa prinaša tudi pritiske na okolje, zaradi česar se je razumevanje sodobnega turizma, tako v strokovni kot v laični javnosti, močno spremenilo. Trajnostni razvoj in družbena odgovornost zajemata vsa področja človekovega delovanja, še posebej pa se v zadnjih letih izpostavljajo ravno v povezavi z razvojem turizma. Družbeno odgovorni, odgovorni, zeleni, sonaravni, trajnostni turizem so pojmi, ki se najpogosteje omenjajo v zvezi s sodobnimi strategijami razvoja turizma tako v Sloveniji kot drugod po svetu (Metelko, 2014; Ministrstvo za gospodarski razvoj in tehnologijo, 2017). Kljub različnim poimenovanjem lahko dokaj hitro ugotovimo, da govorimo o konceptu trajnosti, ki poudarja prijazen odnos do narave ter izpostavlja dolgoročne pozitivne vplive na kulturno, ekonomsko in družbeno okolje. Na vseh predhodno omenjenih področjih nam trajnostna usmeritev prinaša spoštljivejši odnos do okolja, poslovnih partnerjev in njihovih interesov, dolgoročno usmerjeno razmišljanje, etično obnašanje ter večje spoštovanje pravic, zakonov in norm obnašanja (Mulej, 2012; Vodeb, 2014). Obravnavano »trajnostno « tematiko lahko umestimo v širši kontekst družbeno odgovornega delovanja. Upoštevanje načel družbeno odgovornega delovanja pa ne predstavlja zgolj kratkoročne poslovne usmeritve (v obliki všečnega slogana 
ali modne muhe), temveč osnovo za premišljeno dolgoročno trajnostno delovanje ter doseganje poslovne odličnosti v vseh gospodarskih panogah, v vseh okoljih in pri vsakem posamezniku.

Preučevanje trajnostnega turizma je v znanstveni literaturi na pomenu pridobilo $v$ devetdesetih letih 20. stoletja. Interes zanj je posledica predvsem okoljskih sprememb ter zavedanja človeka o krhkosti naravnega, kulturnega in družbenega okolja. Sodobni teoretični pristopi in spoznanja ter posledično družbeno zavedanje o pomenu trajnostnega razvoja so predvsem rezultat globljega (s)poznavanja vplivov turizma na širše okolje. Dwyer (2005) navaja, da je z razvojem turistične industrije relativno kmalu postalo jasno, da turizem prinaša tudi določena tveganja in pritiske na okolje. Podobno ugotavlja tudi Mihalič (2006), ki navaja, da se je koncept trajnostnega turizma razvil iz koncepta trajnostnega razvoja in predstavlja enega izmed najbolj priznanih konceptov okolju prijaznega turizma. Danes je koncept tajnostnega turizma znanstveno dobro preučen, saj so ga tako v tujini ${ }^{2}$ (Basu, 2017; Cheng in Wu, 2015; Din, 2018; Jamal in Camargo, 2014) kot v Sloveniji (Bitenc, 2017; Juvan in Dolničar, 2014; Mihalič, 2016; Omerzel Gomezelj, 2016; Sasidharan in Križaj, 2018) preučevali številni znanstveniki, koncept trajnostnega turizma pa je ena izmed najpogosteje obravnavanih tem v sodobni znanstveni literaturi. Posledično so nastale številne definicije, ki kljub različnim obdobjem nastanka težijo $\mathrm{k}$ poudarjanju in tolmačenju istega bistva. Trajnostni turizem predstavlja obliko razvoja, ki je v skladu s potrebami sedanjega človeškega rodu, ne da bi pri tem ogrožali možnosti razvoja prihodnjih generacij (Glasbergen in Driessen, 2002; United Nations Environment Programme in World Tourism Organization, 2005). Kompleksnost in širino términa nazorno ponazori Weaver (2006), ki v svojem delu poudari, da nikakor ne gre za posamično vrsto turizma, temveč za celostni pristop k načrtovanju vseh segmentov turistične industrije, ki vključuje tako ponudnike kot potrošnike.

Ena izmed prvih slovenskih definicij (Zorko, 1999) trajnostni turizem poimenuje kar trajni turizem. Avtor navaja, da je to turizem, ki

2. Mednarodna založba Routledge od leta 1993 izdaja znanstveno revijo Journal of Sustainable Tourism, ki objavlja znanstvena dela s področja trajnostnega razvoja turizma. Predstavitev raziskav s področje trajnostnega razvoja je mogoče zaslediti v številnih tujih in domačih znanstvenih in strokovnih edicijah. 
ne izčrpava naravnih in družbenih virov, ne gre prek meja naravnih in družbenih zmogljivosti, ampak omogoča trajnostni razvoj (Zorko, 1999, str. 26). Mihalič (2006, str. 87) trajnostni turizem opisuje kot posledico koncepta trajnostnega razvoja, ki se še vedno razvija in je ekološko zadovoljiv, ekonomsko uspešen, popularen in družbeno priznan.

Predhodno predstavljenim tujim in slovenskim avtorjem pa so, ne glede na obdobje, v katerem so pisali o trajnostnem turizmu, skupne predvsem sledeče ugotovitve (Omerzel Gomezelj, 2016; Metelko, 2014):

- razumevanje trajnostnega turizma kot širšega koncepta;

- pozitiven vpliv trajnostnega turizma na ekonomsko, socialno in naravno okolje;

- načrtovanje turizma z upoštevanjem vseh vplivov na socialno in naravno okolje;

- sinergija pozitivnega ekonomskega vpliva z ohranjanjem okolja;

- načrtovana oblika turizma, ki temelji na principu dolgoročnosti.

Trajnostni turizem vzpostavlja ustrezno ravnovesje med okoljski$\mathrm{mi}$, gospodarskimi in socialno-kulturnimi vidiki razvoja ter igra pomembno vlogo pri ohranjanju biotske raznovrstnosti. Zmanjšati poizkuša vpliv na okolje in družbo, tako da bosta na voljo tudi prihodnjim generacijam, hkrati pa prispeva k ustvarjanju dohodka, zaposlovanju in ohranjanju lokalnih ekosistemov. Svetovna turistična organizacija Združenih narodov (United Nations World Tourism Organisation, unWTo), je v svojem okoljskem programu opredelila tri vrste pozitivnih in negativnih turističnih vplivov, in sicer glede na njihov gospodarski, družbeno-kulturni in ekološki vpliv. Na okolje namreč vplivajo vsi, ki so kakorkoli vključeni v turistično dejavnost. Svetovna komisija za okolje in razvoj (World Commission on Environment and Development - WCED) je že leta 1987 v t.i. Brundlandtovem poročilu obravnavala nasprotja med ekonomijo in ekologijo, pri čemer je poizkušala ta nasprotja preseči s konceptom trajnostnega razvoja (Bitenc, 2017). Komisija (WCED) je trajnostni turizem opredelila kot turizem, ki zadovoljuje tako potrebe in pričakovanja sedanje generacije, hkrati pa ne zmanjšuje možnosti bodočim gene- 
racijam, da bodo zadovoljile svoje lastne potrebe. Trajnostni turizem posledično lahko razumemo kot »etos«, ki usmerja razvoj turistične dejavnosti. Kot takšen je sestavni del vseh vidikov razvoja in upravljanja turizma, njegov cilj pa ohranjanje gospodarskih in družbenih koristi, ki jih prinaša turistični razvoj ob zmanjševanju, oz. ublažitvi neželenih učinkov na naravno, zgodovinsko, kulturno in/ali družbeno okolje. Pomemben razvojni element trajnostnega upravljanja je uravnoteženje potreb turistov s cilji ponudnika oz. destinacije. Zelen, trajnosten in odgovoren razvoj je prepoznan kot trden temelj razvoja turizma med turističnimi deležniki $\mathrm{v}$ javnem in zasebnem sektorju. Ti podpirajo ohranjanje in varovanje naravnih ter kulturnih danosti in dediščine ter odgovorno in trajnostno turistično valorizacijo (Ministrstvo za gospodarski razvoj in tehnologijo, 2017). K. Vodeb (2014, str. 105) navaja, da je turizem nemogoče razvijati brez vpliva na okolje, vendar je s turističnim razvojem potrebno upravljati tako, da se negativni učinki minimizirajo, pozitivni pa maksimirajo. J. Apih (osebna komunikacija, 23. november 2018) trajnostni turizem razume kot pot do zadovoljnega potrošnika, uspešne lokalne skupnosti in zdravega okolja, pri čemer izpostavlja, da alternativa trajnostnemu razvoju preprosto ne obstaja. V tem pogledu trajnostni turizem razumemo predvsem kot paradigmo sodobnega turističnega razvoja.

\section{Koncept trajnostnega razvoja}

Pri razumevanju koncepta trajnostnega turizma je ključno zavedanje, da trajnostni turizem ne predstavlja specifične vrste (pojavne oblike) turizma oz. turističnega produkta (npr. ekoturizem, ekološki turizem, naravni turizem itd.), temveč zajema vse vrste turizma, ki se ravnajo po trajnostnem konceptu. Trajnostni koncept vključuje vse deležnike v turizmu - trajnostno usmerjenost ponudnikov na trgu, trajnostno usmerjenost povpraševalcev, trajnostno usmerjenost organizatorjev prireditev, načrtovalcev razvojnih politik, trajnostno sklepanjr partnerstev ter trajnostne trženjske produkte in storitve. Prav tako ne smemo pozabiti, da se trajnost ne nanaša na le naravno okolje (npr. izčrpavanje naravnih virov, posegi v naravno okolje, izpusti, $\mathrm{CO}_{2}$ itd.), ampak tudi na kulturno (npr. kulturna nasprotja, izguba identitete in prvotnih vrednot itd.), ekonomsko (npr. ekonomski napredek, generiranje delovnih mest, razvoj infrastrukture itd.) 
Preglednica 2.1 Štirje stebri trajnostnega razvoja turizma

\begin{tabular}{llll}
\hline Gospodarski & Okoljski & Družbeno-kulturni & Podnebni \\
\hline Zagotoviti konku- & Zmanjšati onesna- & Ohranjati in izbolj- & V zadnjem ob- \\
renčnost in spo- & ženost zraka, vode & ševati kakovost ži- & dobju se trem ste- \\
sobnost preživetja & in zemlje ter količi- & vljenja v lokalnih & brom dodaja še \\
turističnih destina- & ne odpadkov, ki jih & skupnostih. Krepiti & vidik podnebnih \\
cij in podjetij, da & ustvarjajo turistič- & in spoštovati kul- & sprememb - cilj je \\
se bodo lahko še & na podjetja, obi- & turno in zgodovin- & zmanjšati vplive \\
naprej razvijala in & skovalci. Ohraniti & sko dediščino, tra- & turizma na podne- \\
prinašala koristi na & in krepiti kakovost & dicijo in različnosti & bje in povečati pri- \\
dolgi rok. & in značilnost po- & destinacije. & lagajanje turizma \\
& krajine. Zavarovati & & podnebnim spre- \\
& in ohranjati nara- & & membam. \\
& vo, rastline in živali. & & \\
\hline
\end{tabular}

Opombe Povzeto po Bitenc (2017) in Slovenska turistična organizacija (2018).

Preglednica 2.2 Cilji in ukrepi trajnostnega turističnega razvoja (UNEP)

\begin{tabular}{|c|c|}
\hline Cilji & Ukrepi \\
\hline $\begin{array}{l}\text { Ekonomska } \\
\text { (gospodarska) } \\
\text { uspešnost }\end{array}$ & $\begin{array}{l}\text { Zagotovitev uspešnega poslovanja konkurenčnosti turističnih de- } \\
\text { stinacij in podjetij na način, da se bodo le-ti lahko razvijali in za- } \\
\text { gotavljali dolgoročne koristi. }\end{array}$ \\
\hline $\begin{array}{l}\text { Lokalna } \\
\text { blaginja }\end{array}$ & $\begin{array}{l}\text { Povečanje deleža, ki ga turizem prispeva k gospodarski blaginji de- } \\
\text { stinacije, vključno s povečanjem deleža porabe obiskovalcev, ki se } \\
\text { ohrani (porabi) lokalno. }\end{array}$ \\
\hline $\begin{array}{l}\text { Kakovost } \\
\text { zaposlovanja }\end{array}$ & $\begin{array}{l}\text { Ohranitev in povečanje števila kakovostnih delavnih mest v turiz- } \\
\text { mu in z njimi povezanih komponent, vključujoč raven plač, pogo- } \\
\text { je za opravljanje dela, dostopnost zaposlitve brez diskriminacije. }\end{array}$ \\
\hline $\begin{array}{l}\text { Socialna } \\
\text { enakost }\end{array}$ & $\begin{array}{l}\text { Široka in družbeno pravična porazdelitev ekonomskih in socialnih } \\
\text { koristi, ki jih prinaša turizem v receptivni destinaciji, vključno z iz- } \\
\text { boljšanjem priložnosti, prihodkov in storitev, ki so na voljo za naj- } \\
\text { revnejše. }\end{array}$ \\
\hline
\end{tabular}

Nadaljevanje na naslednji strani

in družbeno okolje (npr. družbeni stres, ki ga prinaša turistični razvoj, razslojevanje in družbena neenakost, porast kriminala itd). Metelko (2014) navaja, da trajnostni turizem predstavlja obliko razvoja človeške družbe, ki se izogiba nevarnostim materialističnega razvoja in zagotavlja biološko raznovrstnost.

Temelj trajnostnega razvoja predstavljajo trije oziroma štirje stebri (glej preglednico 2.1), zagotavljanje trajnostnega razvoja pa pomeni iskanje ravnovesja med ekonomskim, družbenim in ekološkim stebrom (Mihalič, 2006). 
Preglednica 2.2 Nadaljevanje s prejšnje strani

\begin{tabular}{|c|c|}
\hline$\overline{C \text { Cilji }}$ & Ukrepi \\
\hline $\begin{array}{l}\text { Zadovoljstvo } \\
\text { obiskovalcev }\end{array}$ & $\begin{array}{l}\text { Zagotovitev varne in kakovostne izkušnje obiskovalcev, ne glede } \\
\text { na spol, raso, invalidnost in/ali druge razlike. }\end{array}$ \\
\hline $\begin{array}{l}\text { Lokalni } \\
\text { nadzor }\end{array}$ & $\begin{array}{l}\text { Vključitev in krepitev lokalnih skupnosti pri načrtovanju in sou- } \\
\text { pravljanju bodočega turističnega razvoja ob posvetovanju in vklju- } \\
\text { čevanju vseh zainteresiranih deležnikov. }\end{array}$ \\
\hline $\begin{array}{l}\text { Blagostanje } \\
\text { lokalne } \\
\text { skupnosti }\end{array}$ & $\begin{array}{l}\text { Ohranitev in krepitev kakovosti življenja v lokalnih skupnostih, } \\
\text { vključujoč različne socialne strukture, pri čemer je prosto omogo- } \\
\text { čen dostop do različnih resursov in podpornih sistemov ob izogi- } \\
\text { banju različnim oblikam socialne degradacije ali izkoriščanja. }\end{array}$ \\
\hline $\begin{array}{l}\text { Kulturno } \\
\text { bogastvo }\end{array}$ & $\begin{array}{l}\text { Spoštovanje in krepitev zavesti o zgodovinski dediščini, avtentični } \\
\text { kulturi, tradiciji in edinstvenosti različnih receptivnih družbenih } \\
\text { skupnosti. }\end{array}$ \\
\hline $\begin{array}{l}\text { Fizična } \\
\text { integriteta }\end{array}$ & $\begin{array}{l}\text { Ohranitev in izboljšanje kakovosti pokrajine, tako mestne kot po- } \\
\text { deželske, ter preprečitev fizične in vizualne degradacije okolja. }\end{array}$ \\
\hline $\begin{array}{l}\text { Biološka } \\
\text { raznovrstnost }\end{array}$ & $\begin{array}{l}\text { Ohranjanje naravnih območij, habitatov, prostoživečih živali in } \\
\text { zmanjšanje oz. preprečitev škode, ki bi jo le-ti lahko utrpeli. }\end{array}$ \\
\hline $\begin{array}{l}\text { Učinkovitost } \\
\text { virov }\end{array}$ & $\begin{array}{l}\text { Zmanjšanje uporabe neobnovljivih virov pri poslovanju in razvoju } \\
\text { turističnih objektov ter storitev. }\end{array}$ \\
\hline $\begin{array}{l}\text { Ekološka } \\
\text { kakovost }\end{array}$ & $\begin{array}{l}\text { Zmanjšanje onesnaženosti zraka, vode in zemlje ter omejitev one- } \\
\text { snaževanja, ki ga povzročajo turistična podjetja in obiskovalci. }\end{array}$ \\
\hline
\end{tabular}

Opombe Povzeto po Notarstefano (2007).

Nekateri avtorji (Basu, 2017) omenjajo še četrti steber (podnebne spremembe) oz. zagovarjajo holistični pristop k trajnostnemu upravljanju z dodajanjem področij (stebrov), kot so zadovoljstvo kupcev, okoljska vzgoja (osveščenost) in politično vodstvo. Takšen pristop zagovarja tudi Program združenih narodov za okolje (United Nations Environment Programme, UNEP), ki predlaga dvanajst ciljev oz. področij trajnostnega turističnega razvoja (slednji vsebinsko smiselno temeljijo na pristopu štirih stebrov). Cilje in ukrepe trajnostnega turističnega razvoja, ki jih opredeljuje UNEP, predstavljamo v preglednici 2.2.

Najpomembnejše je spoznanje, da je koncept trajnostnega razvoja neskončen proces, ki ga je potrebno nenehno razvijati in prilagajati, saj so načela trajnosti pod vplivom različnih interesov (Galič, 2013). Kot navaja Bitenc (2017), se drastično spreminjajo tudi potovalne navade in pričakovanja sodobnih popotnikov, saj večina turistov od ponudnikov pričakuje trajnostno usmerjeno poslovanje pogosto se v praksi pojavlja izraz »zeleni« trg (angl. Green Market). 


\section{Opredelitev modelov in indikatorjev trajnostnega razvoja v turizmu}

Modeli trajnostnega razvoja v turizmu so pomembi zato, ker predstavljajo konceptualno podlago za razvoj certifikacijskih shem in znakov. UNwTo je že leta $1996^{3}$ izdala priročnik za turistične menedžerje (World Tourism Organization, 1996), ki vsebuje napotke glede ključnih indikatorjev trajnostnega razvoja v turizmu (indikatorji so predstavljeni v nadaljevanju). Leta 2004 je bila izdana dopolnjena publikacija, ki opredeljuje indikatorje trajnostnega razvoja za turistične destinacije (World Tourism Organization, 2004).

Indikatorji (kazalci in/ali kazalniki) trajnostnega razvoja so vrednostna merila za spremljanje in vrednotenje stanja in razvoja trajnostnega turizma. Mihalič (2006) navaja, da z njihovo pomočjo predvsem izvajamo meritve sprememb $\mathrm{v}$ turističnem sistemu in njegovem okolju. Agencija Republike Slovenije za okolje (ARso) jih opredeljuje kot na dogovorjen način izbrane in predstavljene podatke, ki jih želimo povezati s cilji okoljske politike. ${ }^{4} \mathrm{~V}$ kolikor se indikatorje pravilno oblikuje in dolgoročno tudi pravilno uporablja, se z njihovo pomočjo lahko izmeri in dokaže vzročno-posledična povezava med turizmom in okoljem. Indikatorji nam predvsem pomagajo razumeti, katere gospodarske in okoljske aktivnosti ter razvojne politike so usmerjene $\mathrm{k}$ trajnostnemu turističnemu razvoju. Njihov osnovni namen je identifikacija, usmerjanje razvoja in posledično zmanjšanje negativnih posledic turizma za predhodno omenjena področja. V tem pogledu lahko indikatorje razumemo predvsem kot investicijo v prihodnost, ki naj bi zmanjšala nevarnost uničenja turističnih privlačnosti za bodoče generacije (Galič, 2013).

Posamezni indikatorji se vsebinsko smiselno dopolnjujejo in povezujejo v skupine kriterijev (imenovane tudi dimenzije ali atributi). V osnovi lahko identificiramo tri $^{5}$ skupine indikatorjev, okoljske, socialno-kulturne oz. družbene ter ekonomske oz. gospodarske, ki sovpadajo s področji trajnostnega razvoja. ${ }^{6}$ Podobno skupine indikatorjev opredeljuje tudi model, ki je nastal v okviru Prostovoljne

3. Vlogo indikatorjev so že leta 1992 prepoznali na Konferenci un v Riu ter v Agendi 21 izpostavili vlogo posameznih držav ter un pri njihovem razvoju.

4. Glej http://kazalci.arso.gov.si/sites/default/zgibanka/vhodna.html.

5. Nekateri avtorji govorijo tudi o institucionalnih kazalnikih.

6. Model trajnostnega razvoja UNwTo iz leta 2004 sicer predeljuje trinajst ključnih področij, ki se v nadaljevanju delijo na posamezna podpodročja. 
iniciative za trajnost v turizmu (Voluntary Initiative for Sustainability in Tourism, VISIT), ${ }^{7}$ in ga je financirala EU. Voluntary Initiative for Sustainability in Tourism (iz leta 2018) opredeljuje štiri skupine indikatorjev, ki vključujejo tri temeljna področja trajnostnega razvoja, obenem pa uvajajo novo dimenzijo - indikatorje politične uresničljivosti. Indikatorji politične uresničljivosti merijo politično (podporno) okolje, ki je ključnega pomena za implementacijo in razvoj trajnostnih politik (trajnostne agende), kot sta obstoj ekološkega menedžmenta in trajnostne turistične strategije ter vključenost vseh akterjev na destinaciji v trajnostni razvoj turizma. Model uvaja tudi predlog nabora univerzalnih (generičnih) kazalnikov, ki naj bi bili primerni za vse turistične destinacije, pri čemer se izpostavlja pomen uspešnega, praktičnega in odgovornega podeljevanja okoljskih certifikatov v turizmu (Bitenc, 2017; Galič, 2013).

Izpostaviti velja tudi nabor indikatorjev, ki jih je razvila Evropska agencija za okolje (European Environmental Agency, EEA). Ta je identificirala dvesto indikatorjev, ki temeljijo na petdelnem okvirju presoje, imenovanem DPSIR, pri čemer ima vsak posamezen nabor svoj namen. Elementi modela so (Ministrstvo za okolje in prostor, 2007):

- Gonilne sile (angl. driving forces) so socialno-ekonomski dejavniki in dejavnosti, ki povzročajo povečanje ali zmanjševanje obremenitev okolja (npr. obseg gospodarskih, prometnih ali turističnih dejavnosti itd.).

- Obremenitve (angl. pressures) sestavljajo neposredne antropogene obremenitve in vplivi na okolje (npr. izpusti onesnaževal ali raba naravnih virov).

- Stanje (angl. states) se nanaša na trenutno stanje in razvoj določenega pojava v okolju, kot so raven onesnaženosti zraka, vodnih teles in tal, raznovrstnost vrst v posamezni geografski regiji, razpoložljivost naravnih virov itd.

- Vplivi (angl. impacts) so učinki spremenjenega okolja na zdravje ljudi in drugih živih bitij.

- Odzivi (angl. responses) so odgovori družbe na okoljske probleme. To so lahko posebni ukrepi države, kot npr. takse na rabo naravnih virov. Pomembne so tudi odločitve podjetij in posa- 
meznikov (npr. naložbe podjetij v nadzor nad onesnaževanjem, nakupi recikliranih dobrin v gospodinjstvih itd).

Agencija Republike Slovenije za okolje pri tem opozarja, da je razvoj indikatorjev dinamičen proces, ki se stalno dopolnjuje in izboljšuje, pri čemer si Agencija prizadeva za izbor takšnih kazalcev, ki bodo odsevali trajnostni vidik okoljske razsežnosti razvoja Slovenije. Modele in indikatorje, ki so pomembni z vidika merjenja in upravljanja trajnostnega razvoja Slovenije, podrobneje obravnavamo v podpoglavju Trajnostna usmeritev slovenskega turizma.

\section{Predstavitev pomembnejših mednarodnih indikatorjev na področju trajnostnega turizma}

\section{Kazalniki trajnostnega razvoja: Agenda 2030}

Na vrhu un o trajnostnem razvoju je bila leta 2015 sprejeta t. i. Agenda 2030 za trajnostni razvoj (The 2030 Agenda for Sustainable Development), ${ }^{8}$ ki predstavlja zgodovinski dogovor mednarodne skupnosti za odpravo revščine, zmanjševanje neenakosti, zagotovitev napredka ter zaščito okolja. Agenda izpostavlja spoštovanje človekovih pravic in enakosti spolov ter zagotavljanje blaginje, miru in varnosti za vse ljudi ter skupnosti. Povezuje tri razsežnosti trajnostnega razvoja - ekonomsko, socialno in okoljsko - in jih prepleta s 17 cilji trajnostnega razvoja (Sustainable Development Goals, SDG). Splošni in konkretni cilji naj bi spodbujali ukrepe na področjih, ki so za človeštvo in naš planet odločilnega pomena. Ta področja so: ljudje, planet, blaginja, mir in partnerstvo. Pomembna značilnost nove agende je univerzalnost: ob upoštevanju nacionalnih okoliščin bodo njene cilje uresničevale vse države sveta, tako države v razvoju kot tudi razvite države. Nabor indikatorjev je za spremljanje napredka pri doseganju 17 ciljev na ravni eu pripravil Eurostat, za Slovenijo pa povzel surs. V nadaljevanju (glej preglednico 2.3) predstavljamo nabor indikatorjev, s katerimi se bodo merili cilji trajnostnega razvoja Slovenije do leta 2030.

Cilji in indikatorji SDG se posredno nanašajo tudi na področje turizma, saj so številni cilji prihodnjega razvoja neposredno povezani s trajnostnim razvojem turistične dejavnosti. $V$ tem pogledu UnWTo poseben poudarek namenja ciljem 8, 12 in 14 (Apih in Ramos, 2018;

8. Glej https://sustainabledevelopment.un.org/post2015/transformingourworld. 
Preglednica 2.3 Cilji in indikatorji trajnostnega razvoja do leta 2030

\begin{tabular}{|c|c|}
\hline Cilji & Indik \\
\hline $\begin{array}{l}\text { vse oblike re- } \\
\text { d po svetu }\end{array}$ & $\begin{array}{l}\text { 1.1 Stopnja tveganja socialne izključenosti. 1.2 Stop- } \\
\text { nja tveganja revščine. 1.3 Stopnja resne materialne } \\
\text { prikrajšanosti. 1.4 Stopnja zelo nizke delovne inten- } \\
\text { zivnosti. 1.5 Stopnja preobremenjenosti s stanovanj- } \\
\text { skimi stroški. 1.6 Delež prebivalstva, ki ima v stano- } \\
\text { vanjih težave s streho, ki pušča, z vlažnimi stena- } \\
\text { mi/temelji/tlemi ali s trhlimi okenskimi okvirji/tlemi. }\end{array}$ \\
\hline $\begin{array}{l}\text { 2. Odpraviti lakoto, za- } \\
\text { gotoviti prehransko var- } \\
\text { nost in boljšo prehrano } \\
\text { ter spodbujati trajnostno } \\
\text { kmetijstvo }\end{array}$ & $\begin{array}{l}\text { 2.1 Prekomerna prehranjenost in debelost odraslega } \\
\text { prebivalstva. } 2.2 \text { Indeks faktorskega dohodka v kmetij- } \\
\text { stvu na polnovredno delovno moč. } 2.3 \text { Državna prora- } \\
\text { čunska sredstva za raziskovalno-razvojno dejavnost, } \\
\text { namenjena kmetijstvu. } 2.4 \text { Delež kmetijskih zemljišč } \\
\text { v uporabi z ekološko pridelavo ali v preusmeritvi. } 2.5 \\
\text { Emisije amonijaka iz kmetijstva. } 2.6 \text { Bruto bilanca hra- } \\
\text { nil na kmetijskih zemljiščih. }\end{array}$ \\
\hline $\begin{array}{l}\text { 3. Poskrbeti za zdravo ži- } \\
\text { vljenje in spodbujati splo- } \\
\text { šno dobro počutje v vseh } \\
\text { življenjskih obdobjih }\end{array}$ & $\begin{array}{l}\text { 3.1 Pričakovano trajanje življenja ob rojstvu. } 3.2 \text { Splo- } \\
\text { šno zdravstveno stanje oseb. } 3.3 \text { Standardizirana stop- } \\
\text { nja umrljivosti zaradi samomora. } 3.4 \text { Delež kadilcev } \\
\text { (rednih in občasnih) med odraslimi. }\end{array}$ \\
\hline $\begin{array}{l}\text { 4. Vsem enakopravno za- } \\
\text { gotoviti kakovostno iz- } \\
\text { obrazbo ter spodbujati } \\
\text { možnosti vseživljenjskega } \\
\text { učenja za vsakogar }\end{array}$ & $\begin{array}{l}\text { 4.1 Delež otrok, vključenih v (predšolsko) izobraževa- } \\
\text { nje, starih od 4. leta do starosti ob vstopu v obvezno } \\
\text { osnovnošolsko izobraževanje. } 4.2 \text { Zgodnja opustitev } \\
\text { izobraževanja. } 4.3 \text { Prebivalstvo s terciarno izobrazbo. } \\
\text { 4.4 Stopnja delovne aktivnosti nedavnih diplomantov. } \\
\text { 4.5 Vključenost odraslih v izobraževanje. 4.6 Nizka ra- } \\
\text { ven pismenosti učencev. }\end{array}$ \\
\hline $\begin{array}{l}\text { 5. Doseči enakost spo- } \\
\text { lov ter krepiti vlogo vseh } \\
\text { žensk in deklic }\end{array}$ & $\begin{array}{l}\text { 5.1 Plačna vrzel med spoloma. } 5.2 \text { Vrzel stopnje delov- } \\
\text { ne aktivnosti po spolu. } 5.3 \text { Delež sedežev, ki jih v naci- } \\
\text { onalnem parlamentu zasedajo ženske. } 5.4 \text { Delež žensk } \\
\text { na vodstvenih položajih. }\end{array}$ \\
\hline
\end{tabular}

Nadaljevanje na naslednji strani

United Nations Environment Programme in World Tourism Organization, 2018).

\section{Global Sustainable Tourism Criteria (GSTC)}

Kriteriji GsTC predstavljajo poizkus poenotenja indikatorjev za trajnostno upravljanje v turizmu na globalni ravni. V osnovi vključujejo 37 oziroma 41 indikatorjev, ki merijo štiri temeljna področja trajnostnega razvoja: trajnostno upravljanje (14 indikatorjev), družbenoekonomsko področje (9 indikatorjev), odnos do lokalnih skupnosti, 
Preglednica 2.3 Nadaljevanje s prejšnje strani

\begin{tabular}{|c|c|}
\hline Cilji & Indik \\
\hline $\begin{array}{l}\text { 6. Vsem zagotoviti dostop } \\
\text { do vode in sanitarne ure- } \\
\text { ditve ter poskrbeti za traj- } \\
\text { nostno gospodarjenje z } \\
\text { vodnimi viri }\end{array}$ & $\begin{array}{l}\text { 6.1 Delež prebivalstva, ki v svojem gospodinjstvu nima } \\
\text { osnovne sanitarne opreme (kadi ali prhe, stranišča na } \\
\text { izplakovanje). } 6.2 \text { Prebivalstvo, priključeno na komu- } \\
\text { nalne čistilne naprave z vsaj sekundarno stopnjo či- } \\
\text { ščenja. } 6.3 \text { Biokemijska potreba po kisiku v rekah. } 6.4 \\
\text { Nitrati v podzemni vodi. } 6.5 \text { Fosfat v rekah } 6.6 \text { Indeks } \\
\text { izkoriščanja vode. }\end{array}$ \\
\hline $\begin{array}{l}\text { 7. Vsem zagotoviti dostop } \\
\text { do cenovno sprejemljivih, } \\
\text { zanesljivih, trajnostnih in } \\
\text { sodobnih virov energije }\end{array}$ & $\begin{array}{l}\text { 7.1 Delež gospodinjstev, ki si ne morejo privoščiti pri- } \\
\text { merno ogrevanega stanovanja. } 7.2 \text { Delež energije iz } \\
\text { obnovljivih virov v bruto končni porabi energije. } 7.3 \\
\text { Oskrba z energijo, poraba končne energije. } 7.4 \text { Konč- } \\
\text { na poraba energije v gospodinjstvih na prebivalca. } 7.5 \\
\text { Energetska odvisnost. } 7.6 \text { Energetska produktivnost. }\end{array}$ \\
\hline $\begin{array}{l}\text { 8. Spodbujati trajnostno, } \\
\text { vključujočo in vzdržno go- } \\
\text { spodarsko rast, polno in } \\
\text { produktivno zaposlenost } \\
\text { ter dostojno delo za vse }\end{array}$ & $\begin{array}{l}\text { 8.1 Realna rast bruto domačega proizvoda na prebival- } \\
\text { ca. 8.2 Mladi, ki niso niti delovno aktivni niti vključeni } \\
\text { v izobraževanje ali usposabljanje. } 8.3 \text { Stopnja delovne } \\
\text { aktivnosti. } 8.4 \text { Stopnja dolgotrajne brezposelnosti. } 8.5 \\
\text { Neprostovoljne začasne zaposlitve. }\end{array}$ \\
\hline $\begin{array}{l}\text { 9. Zgraditi vzdržljivo in- } \\
\text { frastrukturo, spodbujati } \\
\text { vključujočo in trajnostno } \\
\text { industrializacijo ter po- } \\
\text { speševati inovacije }\end{array}$ & $\begin{array}{l}\text { 9.1 Delež bruto domačih izdatkov za raziskave in ra- } \\
\text { zvoj v bruto domačem proizvodu. } 9.2 \text { Delovno aktiv- } \\
\text { ni v visoko in srednje visoko tehnoloških proizvodnih } \\
\text { sektorjih in v na znanju temelječih storitvenih sektor- } \\
\text { jih. 9.3 Skupno število zaposlenih oseb v raziskavah } \\
\text { in razvoju. 9.4 Prijave patentov na Evropski patentni } \\
\text { urad. 9.5 Delež javnega potniškega prevoza v skupnem } \\
\text { kopenskem prevozu. 9.6 Delež železniškega blagovne- } \\
\text { ga prevoza v skupnem kopenskem blagovnem prevozu. }\end{array}$ \\
\hline
\end{tabular}

Nadaljevanje na naslednji strani

obiskovalcev in kulturne dediščine (6 indikatorjev) ter okoljsko delovanje (12 indikatorjev).$^{9}$ Glede na vrsto turističnih ponudnikov se kriteriji v osnovi delijo na indikatorje za hotele in organizatorje potovanj (angl. Global Sustainable Tourism Criteria for Hotels and Operators) ter indikatorje za turistične destinacije (angl. Global Sustaina-

9. Na področju okoljskega delovanja kriteriji GsT vključujejo nabor 12 indikatorjev, ki se lahko prilagajajo specifikam poslovnega okolja (več v nadaljevanju): nevarnosti za okolje, zaščita prosto živečih živali, upravljanje z energijo, upravljanje z vodnimi viri - varnost voda, upravljanje z odpadnimi vodami, svetlobno in zvočno onesnaževanje, zaščita ranljivih okolij in habitatov, emisije plinov, upravljanje z vodnimi viri splošno, upravljanje z vodnimi viri - kakovost voda, upravljanje z vodnimi viri - odpadne vode, transport. Glej https://www.gstcouncil.org/gstc-criteria. 
Preglednica 2.3 Nadaljevanje s prejšnje strani

\begin{tabular}{|c|c|}
\hline 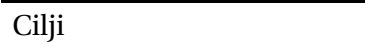 & Indikatorji \\
\hline $\begin{array}{l}\text { 10. Zmanjšati neenakosti } \\
\text { znotraj držav in med njimi }\end{array}$ & $\begin{array}{l}\text { 10.1 Bruto domači proizvod na prebivalca v standardih } \\
\text { kupne moči. 10.2 Prilagojeni bruto razpoložljivi doho- } \\
\text { dek gospodinjstev na prebivalca v standardih kupne } \\
\text { moči. 10.3 Relativna vrzel tveganja revščine. 10.4 Gini- } \\
\text { jev količnik ekvivalentnega razpoložljivega dohodka. } \\
\text { 10.5 Delež skupnega razpoložljivega dohodka v spo- } \\
\text { dnjih 4. decilih (dohodek na ekvivalentnega odraslega } \\
\text { člana gospodinjstva). 10.6 Število prošenj za azil (sku- } \\
\text { paj in ugodene). }\end{array}$ \\
\hline $\begin{array}{l}\text { 11. Poskrbeti za odprta, } \\
\text { varna, vzdržljiva in trajno- } \\
\text { stna mesta in naselja }\end{array}$ & $\begin{array}{l}\text { 11.1 Stopnja prenaseljenosti glede na stopnjo urbani- } \\
\text { zacije. 11.2 Umrli zaradi posledic transportnih nezgod. } \\
\text { 11.3 Izpostavljenost urbanega prebivalstva onesnaže- } \\
\text { nju zraka s trdnimi delci. 11.4 Delež prebivalstva, ki ži- } \\
\text { vi v gospodinjstvih, ki trpijo zaradi hrupa. 11.5 Stopnja } \\
\text { recikliranja komunalnih odpadkov. }\end{array}$ \\
\hline $\begin{array}{l}\text { 12. Zagotoviti trajnostne } \\
\text { načine proizvodnje in po- } \\
\text { rabe }\end{array}$ & $\begin{array}{l}\text { 12.1 Nastajanje odpadkov brez mineralnih odpadkov. } \\
\text { 12.2 Stopnja recikliranja in odlaganja odpadkov brez } \\
\text { mineralnih odpadkov. } 12.3 \text { Snovna produktivnost. } 12.4 \\
\text { Povprečni izpusti } \mathrm{CO}_{2} \text { na kilometer pri novih osebnih } \\
\text { avtomobilih. } 12.5 \text { Obseg blagovnega prevoza glede na } \\
\text { bruto domači proizvod. }\end{array}$ \\
\hline $\begin{array}{l}\text { 13. Sprejeti nujne ukrepe } \\
\text { za boj proti podnebnim } \\
\text { spremembam in njihovim } \\
\text { posledicam }\end{array}$ & $\begin{array}{l}\text { 13.1 Emisije toplogrednih plinov. 13.2 Emisijska inten- } \\
\text { zivnost pri porabi energije. 13.3 Financiranje projektov } \\
\text { in izvajanje aktivnosti za blaženje in/ali prilagajanje } \\
\text { na podnebne spremembe v partnerskih državah v ra- } \\
\text { zvoju. }\end{array}$ \\
\hline $\begin{array}{l}\text { 14. Ohranjati in vzdržno } \\
\text { uporabljati oceane, mor- } \\
\text { ja in morske vire za trajno- } \\
\text { stni razvoj }\end{array}$ & $\begin{array}{l}\text { 14.1 Delež kopališč kopalnih voda, ki imajo odlično ka- } \\
\text { kovost, skladno s priporočenimi zahtevami. } 14.2 \text { Zado- } \\
\text { stnost morskih območij, določenih v evropski Direkti- } \\
\text { vi o habitatih. } 14.3 \text { Morski gospodarski ribolov. }\end{array}$ \\
\hline
\end{tabular}

Nadaljevanje na naslednji strani

ble Tourism Criteria for Destinations). Destinacijski kriteriji vključujejo enaka področja kot kriteriji za turistične ponudnike (Apih in Ramos, 2018). Kriteriji temeljijo na večdesetletnih izkušnjah trajnostnega upravljanja turističnih destinacij, upoštevajo sodobne smernice, načela in standarde trajnostnega turizma $\mathrm{z}$ različnih celin, s ciljem vzpostavitve globalnega konsenza o trajnostnem turizmu (Slovenska turistična organizacija, 2018). Kriteriji jasno opredeljujejo, kaj mora biti narejeno na področju trajnosti, ter to s pomočjo indikatorjev tudi merijo (temeljijo na numerično izraženih vrednostih). Bitenc (2017) 
Preglednica 2.3 Nadaljevanje s prejšnje strani

\begin{tabular}{|c|c|}
\hline Cilji & Indikatorji \\
\hline $\begin{array}{l}\text { 15. Varovati in obnoviti } \\
\text { kopenske ekosisteme ter } \\
\text { spodbujati njihovo trajno- } \\
\text { stno rabo, trajnostno go- } \\
\text { spodariti z gozdovi, bori- } \\
\text { ti se proti širjenju puščav, } \\
\text { preprečiti degradacijo ze- } \\
\text { mljišč in obrniti ta pojav } \\
\text { ter preprečiti izgubo biot- } \\
\text { ske raznovrstnosti }\end{array}$ & $\begin{array}{l}\text { 15.1 Delež gozda v skupni površini države. 15.2 Indeks } \\
\text { ptic kmetijske krajine. } 15.3 \text { Zadostnost kopenskih ob- } \\
\text { močij, določenih v evropski Direktivi o habitatih. }\end{array}$ \\
\hline $\begin{array}{l}\text { 16. Spodbujati miroljub- } \\
\text { ne in vključujoče družbe } \\
\text { k trajnostnemu razvoju, } \\
\text { vsem omogočiti dostop do } \\
\text { pravnega varstva ter obli- } \\
\text { kovati učinkovite, odgo- } \\
\text { vorne in odprte ustanove } \\
\text { na vseh ravneh }\end{array}$ & $\begin{array}{l}\text { 16.1 Umrljivost zaradi napadov. 16.2 Delež gospodinj- } \\
\text { stev, ki so poročala, da imajo v svojem okolišu težave s } \\
\text { kriminalom, z nasiljem ali vandalizmom. 16.3 Skupni } \\
\text { izdatki države za sodišča. } 16.4 \text { Indeks zaznavanja ko- } \\
\text { rupcije. 16.5 Zaznana neodvisnost pravosodnega siste- } \\
\text { ma. 16.6 Stopnja zaupanja državljanov v institucije EU. }\end{array}$ \\
\hline $\begin{array}{l}\text { 17. Okrepiti načine in sred- } \\
\text { stva za izvajanje ciljev ter } \\
\text { oživiti globalno partner- } \\
\text { stvo za trajnostni razvoj }\end{array}$ & $\begin{array}{l}\text { 17.1 Uradna razvojna pomoč kot delež bruto nacional- } \\
\text { nega dohodka. 17.2 Financiranje držav v razvoju. } 17.3 \\
\text { Uvoz iz držav v razvoju. } 17.4 \text { Bruto dolg sektorja dr- } \\
\text { žava. } 17.5 \text { Delež okoljskih davkov in davkov na delo v } \\
\text { skupnih davčnih prihodkih. }\end{array}$ \\
\hline
\end{tabular}

Opombe Povzeto po Ministrstvo za okolje in prostor (http://www.mop.gov.si) in United Nations (2018).

navaja, da se kriteriji lahko prilagodijo posameznim lokalnim specifičnostim (npr. človekove pravice, zaposlitvena politika, odnos do lokalne skupnosti, kakovost itd.) ter predstavljajo minimalni standard, ki ga turistične destinacije in/ali turistična podjetja morajo doseči na področju trajnostnega razvoja turizma. Kriteriji so bili leta 2016 revidirani in usklajeni s potrebami turističnega gospodarstva. Rezultat posodobitve je vključitev indikatorjev s področja ravnanja z odpadki ter zaščite živali. Kriteriji GSTC služijo tudi kot smernice za trajnostno delovanje turističnih ponudnikov in certifikacijskih shem benchmarking ter trajnostnih modelov v turizmu' ${ }^{10}$ (Apih in Ramos,

10. To poteka na dveh ravneh. Na prvi stopnji se lahko uporablja lastna shema oz. model certificiranja, ki temelji na kriterijih GST. Usklajenost potrdi neodvisni akreditacijski odbor. Šele po zaključku začetne faze lahko upravitelj sheme, ki je bila prvotno usklajena in priznana s strani GSTC, zaprosi za popolno akreditacijo GSTC. Trenutno je registriranih 28 globalnih certifikacijkih shem, ki so akreditirane s strani GSTC, 
2018). Organizacijo Global Sustainable Tourism Council (GSTC) podrobneje predstavljamo v nadaljevanju (glej podpoglavje Pomembnejše mednarodne organizacije in okoljski znaki za trajnostni turizem).

\section{Green Destination Standard (GDS)}

Green Destinations ${ }^{11}$ je globalna neprofitna mreža oz. združenje ambicioznih destinacij, ki želijo izboljšati svojo trajnostno usmerjenost. Green Destinations predstavlja organizacijsko platformo, ki zagotavlja vrednotenje in skrbi za promocijo istoimenske blagovne znamke. Njene primarne naloge vključujejo upravljanje z orodjem Green Destination Standard, ocenjevanje destinacij, promocijo in podporo pri trženju trajnostnih destinacij ter izobraževanje partnerjev in nacionalnih ocenjevalcev. ${ }^{12}$ Najboljše destinacije, članice mreže Green Destinations, se na osnovi vsakoletnega tekmovanja potegujejo za uvrstitev na prestižni seznam тop 100 Sustainable Tourism Destinations.

Izpostaviti velja, da se je prvotno orodje imenovalo Global Sustainable Tourism Review (GSTR) leta 2016 preimenovalo v Green Destination Standard. Za razliko od GSTR je Green Destination Standard certificiran in akreditiran s strani GSTC. ${ }^{13}$

Green Destination Standard ${ }^{14}$ vsebinsko temelji na mednarodno uveljavljenih indikatorjih trajnostnega razvoja turističnih destinacij - Globalnih kriterijih za trajnostni razvoj turističnih destinacij (GSTC), postopkovno pa povzema korake, zapisane v Evropskih indikatorjih za trajnostno upravljanje turističnih destinacij (ETIS, več v nadaljevanju).

Z uporabo metodologije Green Destination Standard je mogoče pristopiti k trajnostnemu upravljanju turističnih destinacij, pred-

od tega jih 12 deluje v EU. Upravitelji shem, ki so akreditirane s strani GsTC, lahko poleg individualnih znakov podeljujejo tudi znak GsTc.

11. Glej http://greendestinations.org.

12. Certificirani partner za Slovenijo je zavod GoodPlace (www.lab-goodplace .com).

13. Od marca 2016 je priznan, od junija 2018 pa je prejel aktreditacijo GsTC.

14. Green Destination Standard (prej GSTR) v osnovi izhaja iz sistema ocenjevanja, s katerim se ocenjuje trajnost in kakovost obalnih destinacij - The Quality Coast Award. Na podlagi omenjenega sistema je bilo razvito tudi začetno orodje GSTR, ki je vključevalo tudi neobalne destinacije. S programom The Quality Coast Award upravlja združenje Coastal \& Marine Union (EUCC). 
vsem pa zagotoviti empirično vrednotenje stanja v posameznih destinacijah. Poleg tega, da sistem temelji na predhodno omenjenih skupinah indikatorjev (GST Criteria in ETIS), omogoča selektivno uporabo določenih indikatorjev, ki so lahko prilagojeni lokalnim specifičnostim posameznih destinacij. Trajnostno usmerjenost destinacije se v osnovi ocenjuje na osnovi 118 indikatorjev, ki pripadajo šestim skupinam atributov: narava, okolje, kultura in tradicija, ljudje - gostoljubnost, zeleno gospodarstvo in zelena politika. Posamezni atributi vsebujejo nabor specifičnih indikatorjev, ki se ocenjujejo (vrednotijo) po lestvici od 1 do 5 . Na podlagi seštevka posameznih ocen je pripravljena končna evalvacija Green Destinations, ki se skladno z metodologijo GSTR meri v razponu od 1 do 10. Orodje omogoča pregleden in merljiv način spremljanja trajnostne usmerjenosti turističnih destinacij, pri čemer uporabnik dobi povratno informacijo o stanju (vrednosti) posameznih indikatorjev, atributov ter končno oceno uspešnosti destinacije. Orodje velja za uporabniku prijazno, odlikujejo pa ga sledeče značilnosti (Bitenc, 2017; Slovenska turistična organizacija, 2018):

- omogoča uporabo tako na globalni kot lokalni ravni,

- uporabnika vodi k izboljšanju trajnosti,

- podaja kvantitativno oceno, kar omogoča primerjavo z drugimi destinacijami,

- omogoča prenos dobrih praks med destinacijami in posameznimi ponudniki,

- samoocenjevanje poteka s strani treh ocenjevalcev,

- orodje omogoča povezavo z rezervacijskimi in s promocijskimi kanali ter tako uporabniku poda pomembno informacijo o trajnostni usmerjenosti posameznih destinacij,

- vsebuje širok nabor indikatorjev ter omogoča spremljanje uspešnosti na dolgi rok,

- destinacije pridobijo končno oceno na osnovi statističnih podatkov, ocen evalvatorjev, samoocene ter povratnih informacij, pridobljenih s strani gostov in certifikacijskih shem.

\section{European Tourism Indicators System for Sustainable Management at Destination Level (ETIS)}

ETIS je upravljavski in informacijski sistem, ki omogoča nadzor nad trajnostnim upravljanjem in razvojem turističnih destinacij. Leta 
2013 ga je oblikovala Evropska komisija na osnovi številnih predhodnih pobud za oblikovanje metodološkega orodja, ki bi omogočalo trajnostno upravljanje EU-turističnih destinacij. Končni nabor indikatorjev je bil oblikovan na podlagi prejetih povratnih informacij iz EU-destinacij, kjer je potekalo pilotno testiranje predlaganega nabora indikatorjev. ETIs temelji na vseh stebrih trajnostnega razvoja turizma ter je primeren za vse vrste turističnih destinacij. Vključuje 27 osnovnih ter 40 izbirnih indikatorjev, ki se delijo na področja - destinacijski menedžment, družbeni in kulturni vpliv, ekonomska korist ter okoljski vpliv. ETıs je metodološko oblikovan kot priročnik. Poleg nabora temeljnih indikatorjev vključuje tudi navodila za zbiranje in obdelavo podatkov ter dopušča možnost prilagoditve potrebam (specifičnostim) posameznih destinacij. Vsak indikator je na podlagi pilotnega testiranja prejel oceno pomembnosti, razpoložljivosti podatkov, stroškov, točnosti, jasnosti in natančnosti. ${ }^{15}$ Po J. Apih (osebna komunikacija, 23. november 2018) kljub številnim naporom Evropske komisije ETIs ni akreditiran s strani GSTC, prav tako pa v praksi ni doživel pričakovanih rezultatov.

\section{Okvirna direktiva o morski strategiji (MSFD)}

Okvirna direktiva o morski strategiji (The Marine Strategy Framework Directive, MSFD) je evropska direktiva, ki določa družbene ukrepe in politike na področju okoljskega upravlanja z morji in morskimi ekosistemi. ${ }^{16}$ Cilji direktive so doseganje in/ali vzdrževanje t.i. dobrih okoljskih stanj (Good Environmental Status, GEs), trajnostno upravljanje ter učinkovita zaščita morij EU. ${ }^{17}$ Morska strategija je dokument, na podlagi katerega si posamezna država članica EU v okviru regije ali podregije prizadeva prispevati k doseganju ciljev Direktive 2008/56/es (Evropski Parlament in Svet Evropske unije, 2008). Cilj je doseganje dobrega okoljskega stanja morskega okolja do leta 2021, zato morajo države članice najpozneje do leta 2020 izvesti potrebne ukrepe za dosego ali ohranitev dobrega okoljskega stanja $\mathrm{v}$ morskem okolju, določene v okviru nacionalne morske strategije. V ta namen morajo države članice za morske vode pod njihovo pristoj-

15. Glej http://www.ecotourism-network.eu/en-ecotourism-standard/en-the -euro-eco-label-stand/item/3o-the-european-ecotourism-labelling-standard.

16. Glej http://www.mop.gov.si/si/delovna_podrocja/voda/okvirna_direktiva _o_morski_strategiji/.

17. Glej http://www.gstc.eu/ 
nostjo in suverenostjo $\mathrm{v}$ medsebojnem sodelovanju $\mathrm{z}$ državami iste morske regije pripraviti morske strategije, ki bodo vključevale presojo vseh človekovih dejavnosti, ki vplivajo na morsko okolje, s cilji, da zagotavljajo varstvo in ohranjanje morskega okolja, preprečijo njegovo propadanje ali, če je mogoče, obnovijo morske ekosisteme na območjih, ki so jih prizadeli škodljivi učinki, ter preprečujejo in zmanjšujejo onesnaževanje morskega okolja in tako zagotavljajo, da ni večjih posledic za morsko biotsko raznovrstnost, morske ekosisteme, človekovo zdravje ali zakonito uporabo morja.

Morsko okolje je dragocena naravna danost, ki jo je potrebno zaščititi s ciljem ohranjanja njene edinstvene biotske raznovrstnosti. MSFD vzpodbuja vključevanje trajnostnih vidikov upravljanja z morskimi ekosistemi na vseh področjih in ravneh upravljanja ter določa obvezne sestavine morske strategije:

- Začetna presoja stanja morskega okolja.

- Določanje dobrega stanja okolja.

- Oblikovanje okoljskih ciljnih vrednosti.

- Program spremljanja stanja.

- Obveščanje in presoja Komisije.

- Programi ukrepov.

- Izjeme.

- Sodelovanje javnosti in informacije javnega značaja.

- Obvestila in presoja Komisije.

- Regionalno sodelovanje.

Evropska omisija je določila kriterije, ki jih je potrebno upoštevati pri pripravi morskih strategij, merila in metodološke standarde za določitev dobrih okoljskih stanj morskih voda ter postopke za izvajanje monitoringa, ocenjevanja in poročanja. MSFD definira dobra okoljska stanja na osnovi enajstih okoljskih deskriptorjev. ${ }^{18}$

- Biotska raznovrstnost se ohranja. Kakovost in prisotnost habitatov ter razporeditev in številčnost vrst so v skladu s prevladujočimi fiziografskimi, geografskimi in podnebnimi pogoji.

- Neavtohtone vrste, ki so posledica človekovih dejavnosti, so na ravneh, ki ne škodujejo ekosistemom. 
- Populacije vseh rib in lupinarjev, ki se izkoriščajo v komercialne namene, so znotraj varnih bioloških meja in imajo takšno razporeditev starosti ter velikosti populacije, ki je značilna za zdrav stalež.

- Vsi elementi morskih prehranjevalnih spletov so, kolikor je znano, prisotni v normalnih količinah in so normalno raznoliki ter se pojavljajo na ravneh, ki lahko zagotavljajo dolgoročno številčnost vrst in ohranitev njihove polne sposobnosti razmnoževanja.

- Evtrofikacija, ${ }^{19}$ ki jo povzroči človek, in zlasti njeni škodljivi učinki, kot so upad biotske raznovrstnosti, degradacija ekosistemov, škodljivo cvetenje alg in pomanjkanje kisika v spodnjih plasteh voda, so minimalni.

- Neoporečnost morskega dna je na ravni, ki zagotavlja zaščito strukture in funkcije ekosistemov ter preprečuje škodljive vplive zlasti na bentoške ekosisteme.

- Trajna sprememba hidrografskih pogojev ne škoduje morskim ekosistemom.

- Koncentracije onesnaževal so na ravneh, ki ne povzročajo onesnaženosti.

- Onesnaževala v ribah in drugi morski hrani, namenjeni za prehrano ljudi, ne presegajo ravni, ki jih določa zakonodaja skupnosti ali drugi ustrezni standardi.

- Lastnosti in količine morskih odpadkov ne škodujejo obalnemu in morskemu okolju.

- Uvajanje energije, vključno s podvodnim hrupom, je na ravneh, ki ne škodujejo morskemu okolju.

\section{Pomembnejše mednarodne organizacije in okoljski znaki za trajnostni turizem}

Turistična podjetja različno pristopajo k reševanju okoljskih problematik in vpeljavi trajnostnih politik. $\mathrm{Z}$ namenom diferenciacije po-

19. Evtrofikacija je proces onesnaževanja, s katerim je povečana količina biomase v vodnih telesih. Posledica povečane količine hranilnih snovi v vodi omogoča razmnoževanje alg in drugih vodnih rastlin, kar pri odmiranju slednjih povzroča zmanjšanje koncentracije kisika. Pomanjkanje kisika pomeni nezadostno preživetje drugih organizmov (žuželk in rib). Najpogostejša vzroka za pojav evtrofikacije sta vnašanje odpadne vode iz kanalizacije in nitratna gnojila. 
nudnikov na trgu obstajajo številni znaki, ki označujejo trajnostno usmerjeno delovanje turističnih ponudnikov. Ker se na trgu pojavljajo številni znaki, se bomo v nadaljevanju osredotočili na znake, ki zagotavljajo verodostojno zunanje priznanje ter v stroki uživajo mednarodni ugled. Predstavljeni znaki so pomembni tudi zato, ker ne poskrbijo zgolj za distinkcijo ponudnikov, temveč na trg prinašajo celovit sistem standardov za vpeljavo trajnostnega koncepta poslovanja, s čimer pomembno prispevajo $\mathrm{k}$ izobraževanju in ozaveščanju ponudnikov ter gostov.

Okoljsko označevanje v turizmu poznamo od osemdesetih let 20 st. Prvotni standardi so se primarno nanašali na zaščito okolja, medtem ko je bil socialno-kulturni vidik dodan kasneje (v Eu po letu 200o). Eden prvih certifikatov v Eu je Modra zastava ${ }^{20}$ (Blue Flag), ${ }^{21}$ ki se je pojavil v Franciji leta 1985, na nivoju eu je bil sprejet leta 1987, od leta 2001 pa velja za globalni certifikat na področju kakovosti voda, okoljske vzgoje in informiranja ter upravljanja in varnosti na področju trajnostnega razvoja naravnih kopališč in marin. Za pridobitev znaka mora destinacija (tako družbena skupnost kot ponudniki) izpolnjevati številne kriterije, ki se nanašajo na kakovost vode, dostopnost okoljskih informacij ter izobraževanje, varnost, storitve in infrastrukturo. V elevacijskem postopku se ocenjuje kakovost plaž, marin, ponudnikov navtičnega turizma, kodeks obnašanja oz. ravnanje lastnikov plovil in jadralcev (Apih in Ramos, 2018).

Konec osemdesetih let (leta 1989) se je v Avstriji pojavil eko certifikat Silberdiestel, ki je prav tako močno vplival na certificiranje v srednji Evropi (predvsem v Avstriji in Nemčiji). Med letoma 1992 in 2002 se je dodatno razvilo več kot 60 prostovoljnih certifikacijskih programov, ki so prav tako zaznamovali ozaveščenost o pomenu trajnostnega razvoja (Bitenc, 2017; Font in Buckley, 2001). Nekontrolirano širjenje certifikacijskih programov pa ni imelo zgolj pozitivnih učinkov, temveč je privedlo do zmede pri uporabnikih (tako gostih kot ponudnikih), zaradi česar je leta $2000 \mathrm{v}$ New Yorku prišlo do sklenitve dogovora (The Mohong Agreement) glede vzpostavitve minimalnih standardov pri podeljevanju certifikatov na področju trajno-

20. Poznamo tudi nacionalni znak Zelena zastava (Green Flag), s katero se označujejo parki in zelene površine v Veliki Britaniji.

21. Leta 2015 je znak Blue Flag prejelo več kot 4.154 plaž in marin. Glej http://www .blueflag.global/. 
stnega turizma. Šele leta 2009 je bil formalno ustanovljen Svet za trajnostni turizem (Sustainable Tourism Stewardship Council), ki se je leta 2010 združil s Partnerstvom za globalne kriterije trajnostnega turizma (Partnership for Global Sustainable Tourism Criteria) v nevladno organizacijo, imenovano Globalni svet za trajnostni turizem (GSTC). ${ }^{22}$ Rezultat organiziranega pristopa na področju trajnostnega turizma je bila vključitev vseh vidikov trajnostnega turizma v certifikacijske programe, GsTc pa velja za globalni referenčni organ na področju trajnostnega turizma.

Apih in Ramos (2018) navajata, da je bilo leta 2017 zgolj v Eu prisotnih 45 mednarodnih znakov za trajnostni turizem. Skupaj s svetovnimi oznakami je evropskim turističnim ponudnikom, tako podjetjem kot destinacijam, na razpolago kar 159 mednarodnih certifikatov in znakov za trajnostni turizem. Avtorja ugotavljata, da je v EU trenutno prisotnih kar $69 \%$ vseh mednarodnih trajnostnih oznak.

\section{Predstavitev izbranih certifikacijskih shem in okoljskih znakov za turistične destinacije}

Na področju trajnostnega upravljanja destinacij lahko zasledimo različne pridevnike, s katerimi označujemo trajnostne certifikacijske sheme ${ }^{23}$ in znake (pogosto zasledimo tudi poimenovanje znamka ali nagrada), kot so: okoljski, eko, zeleni, sonaravni itd. Številne sheme in znaki imajo podobne značilnosti, med seboj pa se najpogosteje razlikujejo glede na geografsko območje (globalne, evropske, regionalne, nacionalne, destinacijske), produktno področje ter organizacijsko-podjetniške značilnosti oziroma področje (klasifikacija shem in znakov), obenem pa se delijo na več kakovostnih ravni oziroma stopenj zaščite (npr. zlati, srebrni, zeleni znak itd.; kategorizacija znotraj istega področja). Bitenc (2017, str. 12) navaja, da je v največjem svetovnem direktoriju okoljskih znakov (Ecolabel In$\mathrm{dex})^{24}$ navedenih preko 460 znakov, ki pokrivajo različna predhodno omenjena področja v različnih državah sveta. Zgolj za področje turizma je navedenih preko 50 okoljskih znakov. Hitro lahko ugotovimo, da je stanje dokaj kaotično in težko pregledno. Posledično uporabniki (tako ponudniki kot gostje) težko prepoznajo koristi, ki

22. Glej https://www.gstcouncil.org/.

23. Certifikacijske sheme pogosto temeljijo na trajnostnih programih.

24. Glej http://www.ecolabelindex.com/. 
jih posamezne sheme oz. znaki prinašajo. Kot pravi J. Apih (osebna komunikacija, 23. november 2018), gostje posledično verjamejo predvsem nacionalnim shemam, saj so jim razumljivejše in jim tudi lažje zaupajo. V nadaljevanju predstavljamo znake, ki so pomembni $z$ vidika trajnostnega razvoja in promocije Slovenije. ${ }^{25}$

Eden izmed najbolj poznanih seznamov (nagrad) na področju trajnostnega upravljanja turističnih destinacije je seznam $100 \mathrm{vr}$ hunskih svetovnih trajnostnih destinacij. Destinacije so na seznam uvrščene na podlagi mednarodnega razpisa, ki mu sledi rigorozni izbirni postopek, v katerem kot ocenjevalci sodelujejo priznani mednarodni strokovnjaki. Med destinacije v kategoriji Best of Planet Best of EU 2018 so uvrščene vse slovenske destinacije, ki sodelujejo v Zeleni shemi slovenskega turizma in so nosilke znaka Slovenia Green Destination, pri čemer sta (trenutno) Ljubljana in Podčetrtek prepoznana kot zlati zeleni destinaciji (Slovenska turistična organizacija, 2018).

Izpostaviti velja tudi znamko Alpski biseri (Alpine Pearls), ${ }^{26} \mathrm{ki}$ združuje alpske počitniške kraje, ki negujejo okolju prijazno mobilnost. Med slovenskimi destinacijami sta člana združenja in nosilca prestižne znamke destinaciji Bled in Bohinj.

EU je leta 2006 s ciljem spodbujanja trajnostnega turističnega razvoja pričela promovirati iniciativo Evropske destinacije odličnosti (European Destinations of Excellence, EDEN). ${ }^{27}$ Podelitev znaka EDEN temelji na meddržavnih tekmovanjih, na osnovi katerih so $\mathrm{v}$ vsaki državi izbrane destinacije odličnosti. Evropska komisija izbor vsako leto posveti drugačni tematiki. Leto 2017 je bilo posvečeno tematiki kulturnega turizma, med osemnajstimi nagrajenimi destinacijami pa je kot edina slovenska zmagovalna destinacija slavil Koper. Prednosti tovrstne iniciative so predvsem promocija netradicionalnih turističnih destinacij, izmenjava izkušenj in primerov dobrih praks ter mreženje nagrajenih destinacij. ${ }^{28} \mathrm{Na}$ nivoju EU velja izpostaviti tudi znak European Ecoturism Labelling Standard (EETLS), ${ }^{29}$

25. Podrobnejša primerjava znakov in shem je bila narejena v študiji Program ekološke ureditve in posodobitve slovenskih hotelov (Ministrstvo za gospodarstvo, 2006).

26. Glej https://www.alpine-pearls.com/sl/o-nas/alpine-pearls/.

27. Glej https://ec.europa.eu/growth/tools-databases/eden/about_en

28. Glej https://ec.europa.eu/growth/tools-databases/eden/about_en.

29. Glej http://www.ecotourism-network.eu/en-ecotourism-standard/en-the -euro-eco-label-stand. 
ki zagotavlja osnovne (minimalne) kakovostne kriterije na področju trajnostnega turizma ter je kompatibilen z ostalimi okoljskimi znaki. EETLS je prav tako priznan s strani GsTC.

\section{Predstavitev izbranih certifikacijskih shem in okoljskih znakov za turistična podjetja}

Na trgu obstajajo številni certifikati in okoljski znaki za turistična podjetja - nastanitvene obrate (No) in turistične agencije ter tour operaterje (TA). Ker je navajanje vseh znakov nesmiselno, se v nadaljevanju osredotočamo na tiste, ki so najpogosteje prisotni na trgu ter predstavljajo enega izmed kriterijev za pridobitev znaka Slovenia Green (Slovenska turistična organizacija, 2018). Zaradi večje preglednosti znake in njihove glavne značilnosti predstavljamo tabelarno (glej preglednico 2.4).

\section{Trajnostna usmeritev slovenskega turizma}

Slovenija ima zaradi naravnih danosti vse predpogoje za razvoj in trženje trajnostnega turizma. Država ima na področju trajnostnega turizma dolgo tradicijo. Prvi formalni zametki trajnostnega razvoja segajo v obdobje vzpostavitve prvih varstvenih režimov (območij) na področju Slovenije (zametki ustanovitve Alpskega varstvenega parka segajo v zgodnja dvajseta leta 20 st., Triglavski narodni park je bil formalno ustanovljen leta 1981, Krajinski park Sečoveljske soline lata 1989 itd.). Upravljanje varovanih območij je Sloveniji prineslo številne dragocene izkušnje in raziskave, ki predstavljajo temelj za uspešno trajnostno usmeritev slovenskega turizma. Trajnostni razvoj turizma v Sloveniji, kot eno izmed temeljnih razvojnih načel, je opredelil že Zakon o spodbujanju razvoja turizma iz leta 2004, ki je tlakoval pot $\mathrm{k}$ strukturiranemu in načrtnemu razvoju trajnostnega turizma v Sloveniji. Vključenost trajnostnega vidika v strateške in operativne dokumente se je nadaljevala, kar je privedlo do nastanka novega promocijskega slogana in blagovne znamke (Slovenia Green/I feel Slovenia), ki sta v center nacionalnih trženjskih aktivnosti umestila neokrnjeno naravo in trajnostno usmeritev slovenskega turizma. Kasneje, leta 2008, se je Slovenija vključila v eden, Ministrstvo za gospodarstvo pa je pričelo spodbujati ponudnike za implementacijo znaka eu Okoljska marjetica.

K aktivnemu razvoju trajnostnega turizma se je zavezala tudi politika na ravni Eu ter posledično v Sloveniji. Z začetkom veljavno- 
Preglednica 2.4 Pomembnejši mednarodni okoljski znaki za turistična podjetja

\begin{tabular}{|c|c|c|c|}
\hline Ime znaka & (1) & $(2)$ & Osnovne značilnosti/spletna stran \\
\hline Bio Hotels & $\mathrm{NE}$ & NA & $\begin{array}{l}\text { Veriga hotelov, katerih ciljna skupina so gostje z visokimi } \\
\text { ekološkimi merili. Visoka merila, ki temeljijo na trajnostni } \\
\text { ekonomiji, organsko pridelani hrani, vključevanju lokalnih } \\
\text { ponudnikov, okolju prijazni energiji, odgovornem ravna- } \\
\text { nju z odpadki in merjenju ogljičnega odtisa. } \\
\text { https://www.biohotels.info }\end{array}$ \\
\hline $\begin{array}{l}\text { EU } \\
\text { Marjetica }\end{array}$ & $\mathrm{NE}$ & NA & $\begin{array}{l}\text { Znak za okolje Eu za turistične nastanitve. Primeren je } \\
\text { za turistične nastanitvene zmogljivosti, vključno s hoteli, } \\
\text { penzioni, planinskimi kočami, z zasebnimi sobodajalci, s } \\
\text { turističnimi kmetijami ter kampi. Podjetja z znakom izpol- } \\
\text { njujejo visoka merila in preverjeno veljajo za okolju prija- } \\
\text { zna. http://ec.europa.eu/environment/ecolabel }\end{array}$ \\
\hline Green Key & DA & NA & $\begin{array}{l}\text { Znak mednarodne fundacije za okoljsko vzgojo FEE za } \\
\text { spodbujanje ozaveščanja in ukrepanja pri okoljski in traj- } \\
\text { nostni problematiki v turistični industriji. Primeren je za } \\
\text { hotele, hostle, manjše nastanitvene objekte, kampe, konfe- } \\
\text { renčne centre, restavracije in atrakcije. Pogoj za pridobitev } \\
\text { znaka je izpolnjevanje vseh obveznih in del izbirnih meril } \\
\text { s področij: okoljski menedžment, vključevanje zaposlenih } \\
\text { v poslovanje podjetja, informacije za goste, voda, pranje } \\
\text { in čiščenje, odpadki, energija, F\&B, notranje okolje, zelene } \\
\text { površine, transport, poslovanje. } \\
\text { http://www.greenkey.global }\end{array}$ \\
\hline $\begin{array}{l}\text { Green } \\
\text { Globe }\end{array}$ & DA & $\begin{array}{l}\text { NA, } \\
\text { TA }\end{array}$ & $\begin{array}{l}\text { Znak za trajnostno poslovanje in menedžment v turiz- } \\
\text { mu od leta 1998. Primeren je za hotele, resorte, tour ope- } \\
\text { ratorje, ponudnike rent-a-car, razstavne in prireditvene } \\
\text { prostore ter druge tipe turističnih podjetij. Sestavljen je } \\
\text { iz } 44 \text { meril in prek 38o kazalnikov, končni nabor pa je od- } \\
\text { visen od tipa ponudnika. Pogoj za pridobitev znaka je iz- } \\
\text { polnjevanje vseh obveznih in dela izbirnih meril, ki pokri- } \\
\text { vajo naslednja področja: trajnostni menedžment, druž- } \\
\text { ba/ekonomija, kulturna dediščina, okolje. } \\
\text { https://greenglobe.com }\end{array}$ \\
\hline
\end{tabular}

Nadaljevanje na naslednji strani

sti Lizbonske pogodbe (1. decembra 2009) je EU pridobila pristojnosti na področju turizma, da lahko podpira, usklajuje in dopolnjuje ukrepe držav članic na tem področju. Na podlagi teh pristojnosti je Evropska komisija objavila dokument Evropa, prva svetovna turistična destinacija - nov okvir evropske turistične politike (Evropska komisija, 2010), v katerem je opredelila štiri prioritetna področja razvoja. Eno izmed teh je tudi spodbujanje razvoja trajnostnega, odgo- 
Preglednica 2.4 Nadaljevanje s prejšnje strani

\begin{tabular}{|c|c|c|c|}
\hline Ime znaka & (1) & (2) & Osnovne značilnosti/spletna stran \\
\hline TourCert & $\begin{array}{l}\mathrm{DA}^{*} \\
\mathrm{NE}^{* *}\end{array}$ & $\begin{array}{l}\text { NA, } \\
\text { TA }\end{array}$ & $\begin{array}{l}\text { Znak za trajnost in družbeno odgovornost podjetij v tu- } \\
\text { rizmu. Primeren je za hotele, tour operatorje in turistične } \\
\text { agencije. Poudarek je na odgovornosti podjetij do družbe } \\
\text { in okolja. Pogoj za pridobitev znaka je izpolnjevanje vseh } \\
\text { meril, ki pokrivajo naslednja področja: menedžment, traj- } \\
\text { nostno poslovanje, ekologija, gostje, zaposleni, viri, doba- } \\
\text { vitelji, vključevanje lokalne skupnosti, preostala ponudba. } \\
\text { Nabor indikatorjev se razlikuje glede na vrsto ponudnika. } \\
\text { https://www.tourcert.org }\end{array}$ \\
\hline Travelife & $\mathrm{DA}$ & $\begin{array}{l}\text { NA, } \\
\text { TA }\end{array}$ & $\begin{array}{l}\text { Znak britanskega združenja turističnih agencij in to- } \\
\text { ur operatorjev ABTA za trajnostno poslovanje in mene- } \\
\text { džment v turizmu. Primeren je za nastanitvene zmogljivo- } \\
\text { sti in TA/To. Z vpeljavo procesnih sprememb pri poslova- } \\
\text { nju pomaga znižati stroške ter izboljšati okoljske, social- } \\
\text { ne in ekonomske vplive. Pogoj za pridobitev znaka za NA } \\
\text { je izpolnjevanje } 163 \text { meril, ki pokrivajo sledeča tematska } \\
\text { področja: menedžment, okolje, skupnost in dobavna veri- } \\
\text { ga. Pogoj za pridobitev znaka Travelife Certified za TA/To } \\
\text { je izpolnjevanje kriterijev s tematskih področij: energetska } \\
\text { učinkovitost, ravnanje z vodo in odpadki, izpusti toplogre- } \\
\text { dnih plinov, delovne prakse, človekove pravice, sodelova- } \\
\text { nje z lokalno skupnostjo, ohranjanje ekosistema, kulturni } \\
\text { vplivi, zdravje in varnost, pravične poslovne prakse, zašči- } \\
\text { ta kupcev, zaščita živali. http://www.travelife.org }\end{array}$ \\
\hline
\end{tabular}

Opombe (1) GSTC priznan. (2) Vrsta obrata. * Za tour operaterje. ${ }^{* *}$ Za hotele in turistične agencije.

vornega in visokokakovostnega turizma (Apih in Ramos, 2018; Novak idr., 2015).

Leta 2009 je Slovenska turistična organizacija dosegla konsenz s turističnim gospodarstvom glede umestitve zelenega turizma med strateške razvojne smernice slovenskega turističnega gospodarstva, kar je privedlo do zavedanja o potrebi po oblikovanju zsst (Bitenc, 2017). Kasneje, leta 2011, je bila podpisana Deklaracija o partnerstvu za trajnostni razvoj slovenskega turizma, v letu 2012 pa je mreža nevladnih organizacij Umanotera - Slovenska fundacija za trajnostni razvoj pripravila alternativni razvojni dokument Plan B 4.0: Za zeleni razvojni preboj, ${ }^{30} \mathrm{ki}$ v celoti poudarja pomen dolgoročnega trajno-

30. Glej https://www.umanotera.org/kaj-delamo/trajne-vsebine-projekti -kampanje/zeleni-razvojni-preboj/ 
stnega razvoja Slovenije. Na trajnostni razvoj je pomembno vplivala Strategija razvoja slovenskega turizma 2012-2016, ki je poudarjala pomen trajnostnega turističnega razvoja Slovenije.

Trajnostni vidik je izpostavljen tudi v obstoječem Zakonu o spodbujanju razvoja turizma (zSRT-1, 2018). Skladno z zakonsko usmeritvijo trajnostni vidik, kot temeljno načelo razvoja slovenskega turizma, upošteva tudi veljavni strateški razvojni dokument za področje turizma na državni ravni - Strategijo trajnostne rasti slovenskega turizma 2017-2021 (Ministrstvo za gospodarski razvoj in tehnologijo, 2017). Strategija temelji na šestih razvojnih področjih (politikah), kar nakazuje potrebo po celostnem pristopu k udejanjanju trajnostnih politik (tako na nacionalnem kot individualnem/operativnem nivoju) (Ministrstvo za gospodarski razvoj in tehnologijo, 2017):

- Mikroregije in turistični produkti.

- Institucionalni in pravni okvir.

- Namestitve, turistična infrastruktura in naložbe.

- Prostor, naravni in kulturni viri.

- Mala in srednje velika podjetja (MSP).

- Kadri v turizmu.

Slovenija je tako jasno izpostavila svojo trajnostno turistično usmeritev ter vzpostavila institucionalni okvir, ki sistematično podpira razvoj trajnostnega turizma. Slednje je za razvoj slovenskega turizma ključnega pomena. Zaradi številnih naravnih danosti trajnostni razvoj predstavlja ključno primerjalno prednost na globalnem turističnem tržišču, obenem pa omogoča kakovostnen razvoj življenjskega prostora.

\section{Zelena shema slovenskega turizma (ZsST) - Slovenia Green}

Na osnovi sprejetih strateških usmeritev je Slovenska turistična organizacija že leta 2014 razvila načrt za izvajanje trajnostnega razvoja slovenskega turizma, imenovan Zelena shema slovenskega turizma (zsst). ${ }^{31}$ Njen namen je bil predvsem oblikovanje metodologije (nacionalnega orodja), ki bi omogočala praktično in učinkovito uvajanje trajnostnih poslovnih modelov v slovenskem turizmu (Slovenska turistična organizacija, 2018). zsst predstavlja celovito zasnovan kon-

31. Razvoj zsst je vodila projektna ekipa zavoda - Zavod tovarna trajnostnega turizma GoodPlace (www.lab-goodplace.com). 
cept za pospeševanje trajnostnega turizma na vseh stebrih trajnostnega razvoja, njen ključni prispevek pa predstavlja zmožnost implementacije akcijskih ukrepov, ki temeljijo na jasno opredeljeni metodologiji in indikatorjih odločanja (slednji so podrobneje predstavljeni v nadaljevanju). zsst je oblikovana na dveh ravneh - na ravni posameznih ponudnikov (nastanitveni obrati, turistične znamenitosti in turistične agencije) ter na ravni turističnih destinacij (občine in parki).

zzsT se trži pod krovno znamko Slovenia Green, ki je uradni naziv zsst. Znamka zagotavlja, da njen nosilec posluje/deluje trajnostno ter omogoča lažjo globalno primerjalno analizo (angl. benchmarking) z ostalimi trajnostnimi destinacijami oz. ponudniki. zssT prav tako predstavlja pomembno promocijsko orodje za izpostavitev destinacij, ki delujejo po trajnostnih načelih, njen namen pa je hitrejše uvajanje trajnostnih modelov v slovenski turizem (Novak idr., 2015; Sasidharan in Križaj, 2018; Slovenska turistična organizacija, 2018).

\section{Ocenjevanje destinacij $v$ Zss T}

Turistične destinacije predstavljajo eno izmed dveh temeljnih ravni delovanja zsst, s čimer zsst teži k razvoju in certificiranju trajnostnega turizma na ravni destinacij in ne zgolj posameznih ponudnikov. Destinacije, ki vstopijo v zsst, imajo možnost pridobiti naziv oz. znak Slovenia Green Destination (bronze/silver/gold). ${ }^{32}$ Znak Slovenia Green Silver prikazujemo na sliki 2.1.

Na osnovi mednarodno uveljavljenega orodja GSTR (GSTR se je preoblikoval v Green Destination Award, o čemer smo že pisali) se je v okviru sheme zsst razvilo nacionalno certifikacijsko orodje. $\mathrm{V}$ nacionalno orodje je slovenski akreditirani partner vključil nabor indikatorjev, ki so del indikatorjev Green Destination Award, ter dodal prilagojen nabor indikatorjev, ki ustrezajo lokalnim karakteristikam trajnostnega turizma v Sloveniji. Certificiranje po shemi zsst temelji na naboru 131 indikatorjev in 100 različnih področij ocenjevanja (atributih). zsst torej v osnovi povzema metodologijo GsTR (Green Destination) ter certifikacijske postopke ETIS-a (EU), kar pomeni, da poleg primerljivega nabora mednarodno akreditiranih indikatorjev (Green Destinations Award) temelji tudi na enakih razvrstitvenih

32. Destinacije Slovenia Green se z vstopom zavežejo k zeleni politiki Slovenia Green ter izpolnjevanju etičnega kodeksa unWTo v turizmu. 

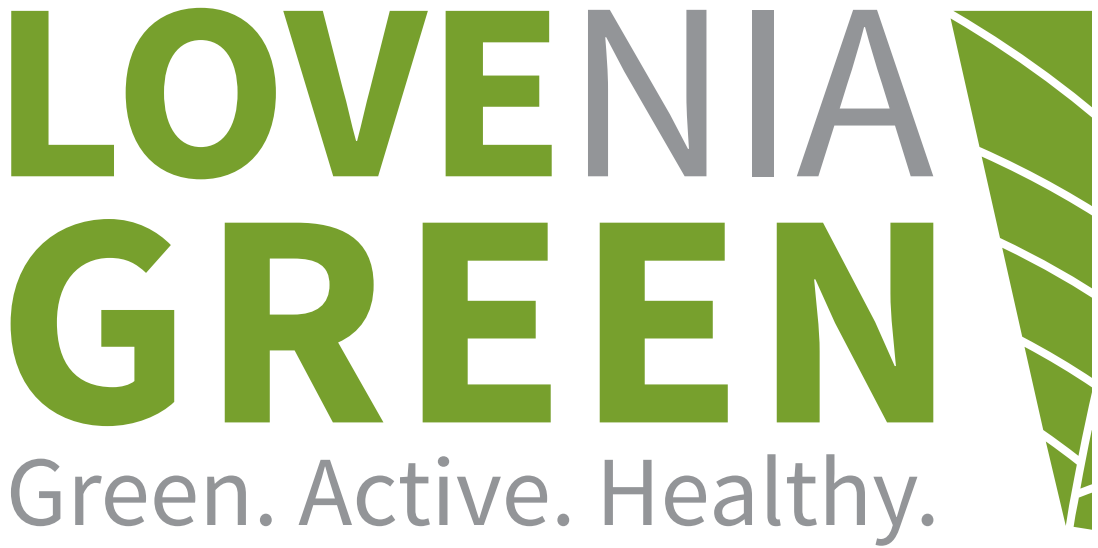

Slika 2.1 Slovenia Green Destination - Silver (Slovenska turistična organizacija, 2018)

kriterijih (od 1 do 10). Posledično zsst posameznim destinacijam in Sloveniji kot celoti omogoča lažjo primerljivost z ostalimi destinacijami, ki so del globalne mreže Green Destinations. Pridobljena ocena trajnosti, poleg primerjalne analize, omogoča tudi lažje vključevanje v promocijske aktivnosti mreže Green Destinations (Slovenska turistična organizacija, 2018).

Upravljalec turistične destinacije (najpogosteje je to angl. Destination management Company (DMO) ali občina), ki želi stopiti v shemo zssT, mora izpolniti prijavnico pri akreditiranem upravljalcu sheme. Izvedba celotnega postopka vključuje enajst ključnih korakov (Novak idr., 2015). Postopek ocenjevanja podrobneje predstavljamo v preglednici 2.5.

V začetnem obdobju ${ }^{33}$ izvajanja zsst so bile $\mathrm{v}$ shemo vključene številne pilotne destinacije, ki so po izvedenem ocenjevanju podale svoje komentarje in predloge za nadgradnjo ter izboljšanje sheme. Bistvena sprememba se nanaša na način izpolnjevanja elevacijskega vprašalnika (orodja zssT), saj je za potrebe ocenjevanja akreditirani partner GoodPlace lansiral uporabniku prijazno spletno platformo, dostop do nabora indikatorjev pa je omogočen samo prijavljenim destinacijam. ${ }^{34}$ Destinacije na tak način na enem mestu zbirajo informacije, ocenjujejo svoje trajnostne pristope ter se po potrebi po-

33. Shema je bila implementirana leta 2015.

34. Glej http://www.slovenia-green.si/index_new.php?menu=membership _greendestinations\&lang=si. 
Preglednica 2.5 Postopek ocenjevanja destinacij v zssT

\begin{tabular}{lll}
\hline Koraki & Aktivnosti \\
\hline 1 & $\begin{array}{l}\text { Imenovanje zelene- } \\
\text { ga koordinatorja }\end{array}$ & $\begin{array}{l}\text { Opredelitev t. i. zelenega koordinatorja, ki skrbi za izpe- } \\
\text { ljavo postopka na destinaciji. }\end{array}$ \\
\hline 2 & $\begin{array}{l}\text { Oblikovanje zelene } \\
\text { ekipe }\end{array}$ & $\begin{array}{l}\text { Oblikovanje t. i. zelene ekipe, ki vključuje ključne pred- } \\
\text { stavnike organizacij, podjetij, posameznikov, ki imajo in- } \\
\text { terese v turizmu. Poleg predstavnikov zasebnega sektorja } \\
\text { morajo biti v ekipo vključeni tudi predstavniki ponudni- } \\
\end{array}$ \\
& kov javnih storitev ter predstavniki lokalnih oblasti. \\
\hline 3 & Osveščanje & $\begin{array}{l}\text { Povečanje ozaveščenosti o pomenu trajnostnega razvo- } \\
\text { ja ter pridobivanje podpore lokalne skupnosti in turistič- } \\
\end{array}$ \\
& $\begin{array}{l}\text { nih ponudnikov je ključen korak, saj mora trajnostni ra- } \\
\text { zvoj postati vzajemen cilj vseh deležnikov, ki delujejo na } \\
\text { destinaciji. }\end{array}$ \\
\hline 4 & Podpis Zelene poli- \\
tike & $\begin{array}{l}\text { Podpis Zelene politike slovenskega turizma. Ta oprede- } \\
\text { ljuje temeljno zavezo slovenskega turizma, da deluje po } \\
\text { načelih trajnostnega razvoja in si nenehno prizadeva za } \\
\text { izboljšave. Podpisnik je navadno župan ali direktor orga- } \\
\text { nizacije prijaviteljice. }\end{array}$ \\
\hline 5 & Anketiranje & $\begin{array}{l}\text { Anketiranje treh skupin deležnikov - lokalnega prebival- } \\
\text { stva, obiskovalcev in turističnega gospodarstva. Ankete } \\
\text { se lahko izvede v spletni ali fizični obliki. }\end{array}$ \\
\hline
\end{tabular}

svetujejo s svetovalci. Svetovalec lahko posledično spremlja in komentira podatke (vnose) posameznih destinacij, s katerimi sodeluje. Platforma omogoča enostavno generiranje poročil ter nudi številne podporne materiale (gradivo). Z namenom lažjega upravljanja računa na omenjenem portalu vsaka destinacija prejme Uporabniški priročnik. V njem je podrobno opisana nadgradnja procesa, ki se nanaša na obvezna dokazila za posamezne kriterije. Nadgradnjo predstavlja tudi posebna razdelitev indikatorjev v tri kategorije, glede na dostopne podatke o posameznem indikatorju, kjer je:

- posamezen indikator že vnesen v platformo, podatek pa je pridobljen iz ustreznih mednarodnih, nacionalnih ali drugih javnih baz oz. drugače izračunan in ga ni mogoče spreminjati;

- posamezen indikator že vnesen v platformo, podatek je pridobljen iz ustreznih mednarodnih, nacionalnih ali drugih javnih baz oz. drugače izračunan in ga je mogoče spreminjati;

- indikator še ni vnesen v spletno platformo, podatke pa vnese destinacija sama. 
Preglednica 2.5 Nadaljevanje s prejšnje strani

\begin{tabular}{lll}
\hline Koraki & Aktivnosti \\
\hline 6 & $\begin{array}{l}\text { Zbiranje in vnašanje } \\
\text { podatkov }\end{array}$ & $\begin{array}{l}\text { Zbiranje podatkov in dokazil omogoča oblikovanje preli- } \\
\text { minarne informacije o trajnostni naravnanosti destinacije. }\end{array}$ \\
\hline 7 & $\begin{array}{l}\text { Oddaja poročila in } \\
\text { zahtevka za presojo }\end{array}$ & $\begin{array}{l}\text { Dokumentoma se doda še analiza anket ter dokazilo o } \\
\text { podpisu t. i. Zelene politike. }\end{array}$ \\
\hline 8 & $\begin{array}{l}\text { Priprava akcijskega } \\
\text { načrta }\end{array}$ & $\begin{array}{l}\text { Priprava načrta ukrepov temelji na zbranih podatkih, nu- } \\
\text { merični oceni in komentarjih ocenjevalca. V načrtu se } \\
\text { podrobno opredeli ukrepe, časovni okvir, finančni okvir } \\
\text { ter odgovorne osebe. }\end{array}$ \\
\hline 9 & $\begin{array}{l}\text { Opredelitev edin- } \\
\text { stvene prodajne } \\
\text { značilnosti }\end{array}$ & $\begin{array}{l}\text { Opredelitev lokalnega značaja in zelene edinstvene pro- } \\
\text { dajne značilnosti (angl. Unique Selling Proposition - UsP) }\end{array}$ \\
\hline 10 & Oddaja zaključnega \\
poročila & $\begin{array}{l}\text { Oddaja poročila in zahtevka za terenski obisk ocenjeval- } \\
\text { cev, na katerem poteka preverjanje zbranih podatkov in } \\
\text { ogled zelenih točk. }\end{array}$ \\
\hline 11 & $\begin{array}{l}\text { Uresničitev ukrepov } \\
\text { in ponovna presoja }\end{array}$ & $\begin{array}{l}\text { Uresničevanje ukrepov in ponovna presoja potekata v } \\
\text { obdobju med 24 in 36 meseci po pridobitvi znaka. V vme- } \\
\text { snem obdobju destinacije uresničujejo sprejeti načrt } \\
\text { ukrepov. }\end{array}$ \\
\hline
\end{tabular}

Opombe Povzeto po GoodPlace (www.lab-goodplace.com) in Novak idr. (2015).

Po izvedeni pilotni fazi je bilo namreč ugotovljeno, da so nekateri podatki že določeni na nacionalni ravni in jih ni mogoče spreminjati. Posledično je za indikatorje, kjer je mogoče podatke spreminjati, potrebno navesti tudi vir, da lahko presojevalec preveri verodostojnost navedenega. Ključna prednost tovrstnega pristopa je v enostavni izvedbi benchmarkinga med posameznimi destinacijami. Destinacije se skladno z metodologijo ocenjujejo periodično (na vsaka tri leta), letno pa se izda poročilo o njihovem trajnostnem udejstvovanju in napredku. Poročila služijo tudi sTo pri pripravi promocijskih aktivnosti, ki temeljijo na promociji Slovenije kot zelene destinacije. Na nivoju turističnih ponudnikov je pridobitev znaka Slovenia Green omogočena tudi tistim certificiranim ponudnikom, ki izpolnjujejo kriterije oz. so nosilci znakov Eu marjetica, Green Globe, Green Key, Travelife, TourCert, Bio Hotels in EcoCamping (Apih in Ramos, 2018).

\section{Konzorcij Slovenia Green}

zssT uvaja sistematični pristop na področju trajnostnega delovanja, zaradi česar je bil s ciljem povezanega in usklajenega delovanja vseh 
ključnih akterjev v okviru zsst leta 2016 ustanovljen konzorcij Slovenia Green. Konzorcij predstavlja formalno združenje destinacij in ponudnikov, ki delujejo na področju trajnostnega razvoja turizma v Sloveniji. Ti poleg članstva v konzorciju postanejo tudi partner v globalni mreži trajnostnih turističnih destinacij Green Destinations. ${ }^{35}$

Konzorcij deluje kot interesno združenje in vključuje konzorcijske partnerje, povezuje pa se tudi s pridruženimi in strateškimi partnerji. Večina destinacij in ponudnikov se srečuje s podobnimi izzivi. Konzorcij svojim članom omogoča lažji pretok ključnih informacij, znanja ter praktičnih rešitev, ki se nanašajo na izvedbo posameznih aktivnosti.

Člani konzorcija se pogodbeno povežejo z sto (kot zunanjim strateškim partnerjem), GoodPlaceom (kot koordinatorjem) ter ostalimi destinacijami in ponudniki, ki so pridobili oz. so v fazi pridobivanja certifikata. Dodatno se s konzorcijem povezujejo tudi pridruženi partnerji (slednji imajo interes povezovanja s ciljem oblikovanja skupnih razvojnih projektov) ter strateški partnerji, ki s svojimi povezavami in interesi pomagajo izpolnjevati in širiti poslanstvo konzorcija. Letne aktivnosti konzorcija se oblikujejo ob zaključku poslovnega leta, v osnovi pa vedno vključujejo aktivnosti povezovanja, razvoja in promocije.

Smotrnost tovrstnega pristopa opravičujejo številne ugledne mednarodne nagrade in priznanja. Slovenija je bila leta $2016 \mathrm{~s}$ strani Green Destinations razglašena za prvo zeleno destinacijo na svetu. Na najpomembnejši svetovni turistični borzi Іт в Berlin, na prestižnem tekmovanju Sustainable Destinations 2018 Top 100, v kategoriji Best of the Planet - Best of Europe pa je bila prepoznana kot ena od desetih najboljših trajnostnih destinacij na svetu in najboljša trajnostna destinacija v Evropi.

\section{Oblikovanje certifikacijske sheme za območje Mediteranske Slovenije}

Na osnovi specifik območja, predstavljenih v prvem poglavju, menimo, da je smiselno pristopiti k oblikovanju merskega inštrumenta, ki je vsebinsko prilagojen za območje slovenskega Mediterana. Izbran metodološki pristop temelji na metodologiji Slovenia Green ter pristopu avtorjev J. Apih in Ramosa (2018) in upošteva specifike preu-

35. Glej http://greendestinations.org/home/introduction/. 
čevanega območja. Ob tem velja izpostaviti, da predloga okoljskega znaka, v trženjskem pomenu, nismo oblikovali. Nov, poenostavljen pristop ne predstavlja konkurence obstoječemu nacionalnemu certifikacijskemu programu, temveč ga, v smislu implementacije trajnostnih načel in aktivnosti na specifičnem geografskem območju, smiselno dopolnjuje.

V prvem koraku smo opredelili ključni ciljni skupini deležnikov v turizmu. Prvo skupino sestavljajo turistični ponudniki, ki so v neposredni interakciji z gosti oz. s turisti, medtem ko so v drugi t.i. nosilci odločanja. Slednji niso v neposrednem stiku z gosti, vendar pomembno vplivajo na razvoj in implementacijo turističnih strategij, raziskav in načrtovanja (obe skupini podrobneje predstavljamo v nadaljevanju). S tovrstnim pristopom želimo pristopiti k obravnavi ključnih deležnikov v turizmu, ki s svojim delovanjem pomembno vplivajo na trajnostni razvoj regije.

Prva skupina - neposredna interakcija z gosti:

- destinacije (občine ali regije),

- zavarovana območja (kopenska in morska),

- ponudniki nastanitev,

- ponudniki storitev prehrambnega gostinstva,

- potovalne agencije in organizatorji potovanj ter ponudniki s turizmom povezanih dejavnosti (animacija, transport, športne aktivnosti itd).

Druga skupina - odločevalci:

- državne in druge uradne službe, ki delujejo na območju Obale (inšpekcijske in svetovalne službe, redarstvo),

- gospodarsko-obrtna in druge zbornice ter vplivna združenja (npr. gospodarsko-interesna združenja), ki delujejo na obalnem območju,

- univerze in raziskovalni centri, ki se ukvarjajo s turizmom in $\mathrm{z}$ varovanjem narave,

- občinski in/ali regionalni ponudniki javnih storitev (podjetja za ravnanje z odpadki, vodo in s kanalizacijo),

- območni zavod(i) za varstvo naravne in kulturne dediščine,

- upravljalci destinacij (občina, DMo). 


\section{Nabor indikatorjev}

Ob upoštevanju specifičnosti preučevanega okolja ter na osnovi preučenih mednarodnih standardov, indikatorjev ter blagovnih znamk smo se pri oblikovanju novega inštrumenta osredotočili na specifične atribute in indikatorje, ki so primerni za področji varovanja naravnega okolja ter trajnostnega turističnega razvoja Mediteranske Slovenije. Predlagane skupine atributov ter spremljajoče indikatorje predstavljamo v preglednici 2.6 na straneh $70-75$.

\section{Predlagani postopek certificiranja}

Na podlagi preučitve različnih sistemov certificiranja in indikatorjev na področju trajnostnega turizma (glej podpoglavje Predstavitev pomembnejših mednarodnih indikatorjev na področju trajnostnega turizma) smo prišli do spoznanja, da je smiselno vpeljati postopek certificiranja, temelječ na več fazah oz. korakih. Pri tem smo se še posebej oprli na spoznanja, do katerih smo prišli pri preučitvi shem oz. metodologij ETıs, Green Destination Award ter Slovenia Green (slednja v osnovi že povzema oba sistema, o čemer smo že pisali). Predlagani postopek temelji na šestih korakih ter štirih pomembnejših sklopih aktivnosti - imenovanje koordinatorja, vzpostavitve zelene ekipe, zbiranja podatkov ter priprava akcijskega načrta. Posamezne korake podrobneje predstavljamo v nadaljevanju.

\section{1. korak: Dvig zavesti}

Ko se destinacija ali podjetje odloči vstopiti v certifikacijsko shemo, je pomembno, da svojo odločitev sporoči čim večjemu številu zainteresiranih deležnikov. Slednje pripomore k ozaveščanju javnosti o strateški zavezanosti prijavitelja $\mathrm{k}$ trajnostnemu turizmu ter poveča podporo javnosti in ključnih akterjev za izvedbo ukrepov, ki jih bo na podlagi rezultatov analize stanja potrebno izpeljati. Slednje prav tako pripomore k javni razpravi o pomenu trajnostnega turističnega razvoja. Ob vstopu v certifikacijsko shemo se za kandidate izvedejo informativne izobraževalne delavnice.

\section{2. korak: Imenovanje zelenega koordinatorja, oblikovanje delovnih skupin in določitev vlog in odgovornosti}

- Zeleni koordinator. Upravitelj certifikacijske sheme imenuje t.i. zelenega koordinatorja. Slednji skrbi za načrtovanje, koordina- 
Preglednica 2.6 Nabor indikatorjev za oblikovanje nove sheme

\begin{tabular}{|c|c|c|c|c|}
\hline \multicolumn{2}{|c|}{ Področje/indikator za destinacije } & \multirow[t]{2}{*}{ (1) } & Indikator za ponudnike & \multirow[t]{2}{*}{ (1) } \\
\hline \multicolumn{3}{|c|}{ 1. Kakovost kopališč } & & \\
\hline 1.A & Številko kopališč. & \multicolumn{3}{|c|}{ Število, vir } \\
\hline 1.B & Število marin. & \multicolumn{3}{|c|}{ Število, vir } \\
\hline 1.C & $\begin{array}{l}\text { Delež kopališč z odlično } \\
\text { oceno kakovosti voda. De- } \\
\text { lež kopališč z dobro oceno } \\
\text { kakovosti voda (skladno z } \\
\text { Direktivo 2006/7/Es). }\end{array}$ & \multicolumn{3}{|c|}{ Delež, vir } \\
\hline 1.D & $\begin{array}{l}\text { Število kopališč in marin s } \\
\text { pridobljenim certifikatom } \\
\text { Modra zastava. }\end{array}$ & \multicolumn{3}{|c|}{ Število, vir } \\
\hline 1.E & $\begin{array}{l}\text { Destinacija spodbuja ko- } \\
\text { pališča in marine k prido- } \\
\text { bitvi certifikata Modra za- } \\
\text { stava. }\end{array}$ & & & \\
\hline 1.F & $\begin{array}{l}\text { Destinacija promovira ko- } \\
\text { pališča in marine, ki so pri- } \\
\text { dobile certifikat Modra za- } \\
\text { stava. }\end{array}$ & $\begin{array}{l}\text { Da/ne, } \\
\text { priloži- } \\
\text { te do- } \\
\text { kazilo }\end{array}$ & $\begin{array}{l}\text { Podjetje aktivno promovira } \\
\text { kopališča in marine, ki so } \\
\text { pridobile certifikat Modra } \\
\text { zastava. }\end{array}$ & $\begin{array}{l}\text { Da/ne, } \\
\text { priloži- } \\
\text { te do- } \\
\text { kazilo }\end{array}$ \\
\hline
\end{tabular}

2. Zaščita okolja in uporabniška izkušnja

\begin{tabular}{llll} 
2.A $\begin{array}{l}\text { Delež zavarovanih narav- } \\
\text { nih kopenskih in morskih } \\
\text { območij po mednarodnih, } \\
\text { regionalnih in lokalnih } \\
\text { standardih. }\end{array}$ & $\begin{array}{l}\text { Delež, } \\
\text { vir }\end{array}$ & $\begin{array}{l}\text { Podjetje deluje v zavarova- } \\
\text { nem območju. }\end{array}$ & $\begin{array}{l}\text { Da/ne, } \\
\text { priloži- } \\
\text { te do- } \\
\text { kazilo }\end{array}$ \\
2.B $\begin{array}{l}\text { Delež nepozidanih povr- } \\
\text { šin. }\end{array}$ & $\begin{array}{l}\text { Delež, } \\
\text { vir }\end{array}$ & \\
2.C $\begin{array}{l}\text { Priložnosti za opazovanje } \\
\text { flore in favne na kopnem } \\
\text { in v morju. }\end{array}$ & $\begin{array}{l}\text { Samoev. Podjetje promovira zašči- } \\
\text { od } 1 \text { do to okolja in svojim gostom } \\
\text { 5, pril. } \\
\text { dok. }\end{array}$ & $\begin{array}{l}\text { Da/negriloži- } \\
\text { in favne. }\end{array}$ & $\begin{array}{l}\text { prilo } \\
\text { te do- } \\
\text { kazilo }\end{array}$ \\
\hline
\end{tabular}

Nadaljevanje na naslednji strani

cijo delovnih skupin, implementacijo in spremljanje indikatorjev trajnostnega razvoja, komunikacijo ter organizacijo usposabljanj.

- Zelena ekipa. Zeleni koordinator mora vzpostaviti t.i. zeleno ekipo, ki jo sestavljajo tisti posamezniki in/ali organizacije, ki bodo odgovorni za zbiranje potrebnih podatkov in informacij, razvoj in izvajanje akcijskih načrtov ter izboljšanje trajnostnega turizma v destinaciji ali v podjetjih. $\mathrm{V}$ ekipo je poleg turistič- 
Preglednica 2.6 Nadaljevanje s prejšnje strani

\begin{tabular}{|c|c|c|c|c|}
\hline \multicolumn{2}{|c|}{ Področje/indikator za destinacije } & \multirow{2}{*}{$\begin{array}{l}(1) \\
\text { Da/ne, } \\
\text { priloži- } \\
\text { te do- } \\
\text { kazilo }\end{array}$} & \multirow[b]{2}{*}{$\begin{array}{l}\text { Indikator za ponudnike } \\
\text { Podjetje je seznanjeno z } \\
\text { načrtom upravljanja s tu- } \\
\text { rističnim obiskom, ki ga je } \\
\text { sprejela destinacija in ga } \\
\text { upošteva pri razvoju turi- } \\
\text { stične ponudbe. }\end{array}$} & \multirow{2}{*}{$\begin{array}{l}\text { (1) } \\
\text { Da/ne, } \\
\text { priloži- } \\
\text { te do- } \\
\text { kazilo }\end{array}$} \\
\hline 2.D & $\begin{array}{l}\text { Destinacija spremlja po- } \\
\text { zitivne in negativne vplive } \\
\text { turizma na ekosisteme, na- } \\
\text { ravne znamenitosti, floro } \\
\text { in favno ter njihove habita- } \\
\text { te. Skladno s tem ima spre- } \\
\text { jet načrt upravljana s turi- } \\
\text { stičnim obiskom. }\end{array}$ & & & \\
\hline 2.E & $\begin{array}{l}\text { Destinacija v skladu z lo- } \\
\text { kalno, nacionalno in med- } \\
\text { narodno zakonodajo in } \\
\text { konvencijami učinkovito } \\
\text { regulira nabiranje, lovlje- } \\
\text { nje, razstavljanje in proda- } \\
\text { jo divjih živali ter rastlin. }\end{array}$ & $\begin{array}{l}\mathrm{Da} / \text { ne, } \\
\text { priloži- } \\
\text { te do- } \\
\text { kazilo }\end{array}$ & $\begin{array}{l}\text { Podjetje sledi lokalni, na- } \\
\text { cionalni in mednarodni } \\
\text { zakonodaji in konvenci- } \\
\text { jam, ki regulirajo nabira- } \\
\text { nje, lovljenje, razstavljanje } \\
\text { in prodajo divjih živali ter } \\
\text { rastlin. }\end{array}$ & $\begin{array}{l}\text { Da/ne, } \\
\text { priloži- } \\
\text { te do- } \\
\text { kazilo }\end{array}$ \\
\hline 2.F & $\begin{array}{l}\text { Obiskovalci so seznanjeni } \\
\text { z bistvenimi vidiki trajno- } \\
\text { sti, kot so naravni, okoljski, } \\
\text { kulturni in družbeni vidik. } \\
\text { Obiskovalci razumejo po- } \\
\text { men svoje vloge pri tem. }\end{array}$ & $\begin{array}{l}\text { Da/ne, } \\
\text { priloži- } \\
\text { te do- } \\
\text { kazilo }\end{array}$ & $\begin{array}{l}\text { Podjetje aktivno promovira } \\
\text { svojo trajnostno usmerje- } \\
\text { nost ter pomen trajnostne- } \\
\text { ga turističnega razvoja. }\end{array}$ & $\begin{array}{l}\text { Da/ne, } \\
\text { priloži- } \\
\text { te do- } \\
\text { kazilo }\end{array}$ \\
\hline 2.G & $\begin{array}{l}\text { Interpretativne informaci- } \\
\text { je ob naravnih in kulturnih } \\
\text { znamenitostih so točne, } \\
\text { nezavajajoče in spoštljive } \\
\text { do različnih kultur in nji- } \\
\text { hovih vrednot. Destinacija } \\
\text { jih oblikuje v sodelovanju z } \\
\text { lokalno skupnostjo. Na vo- } \\
\text { ljo so v več jezikih (glede } \\
\text { na najpogostejše emitivne } \\
\text { države). }\end{array}$ & $\begin{array}{l}\mathrm{Da} / \text { ne, } \\
\text { priloži- } \\
\text { te do- } \\
\text { kazilo }\end{array}$ & & \\
\hline
\end{tabular}

Nadaljevanje na naslednji strani

nih ponudnikov smiselno vključiti tudi predstavnike odločevalcev ter tako doseči čim širši konsenz o pomenu trajnostnega razvoja.

Zeleni koordinator lahko usklajuje delo več zelenih ekip.

- Določite vloge in odgovornosti. Prvi podkorak predstavlja informiranje potencialnih članov ekipe ter vabilo na informativno delavnico ali sestanek. Slušatelje seznanimo s filozofijo trajnosti, pristopi k trajnostnem upravljanju, postopkom certificira- 
Preglednica 2.6 Nadaljevanje s prejšnje strani

\begin{tabular}{|c|c|c|c|c|}
\hline \multicolumn{2}{|c|}{ Področje/indikator za destinacije } & (1) & Indikator za ponudnike & (1) \\
\hline 2.H & $\begin{array}{l}\text { Destinacija obiskovalcem } \\
\text { omogoča opravljanje vo- } \\
\text { lonterskega dela in/ali od- } \\
\text { dajo prostovoljnih finanč- } \\
\text { nih prispevkov, ki so na- } \\
\text { menjeni razvoju družbe in } \\
\text { ohranjanju naravne biot- } \\
\text { ske raznovrstnosti. }\end{array}$ & $\begin{array}{l}\text { Da/ne, } \\
\text { priloži- } \\
\text { te do- } \\
\text { kazilo }\end{array}$ & $\begin{array}{l}\text { Podjetje podpira in promo- } \\
\text { vira destinacijsko politiko, } \\
\text { ki obiskovalcem omogoča } \\
\text { opravljanje volonterskega } \\
\text { dela in/ali oddajo prosto- } \\
\text { voljnih finančnih prispev- } \\
\text { kov, ki so namenjeni razvo- } \\
\text { ju družbe in ohranjanju bi- } \\
\text { otske raznovrstnosti. }\end{array}$ & $\begin{array}{l}\text { Da/ne, } \\
\text { priloži- } \\
\text { te do- } \\
\text { kazilo }\end{array}$ \\
\hline
\end{tabular}

3. Ravnanje z odpadki

3.A Delež trdnih odpadkov, ki so na destinaciji zbrani ločeno.
Delež, Delež trdnih odpadkov, ki

Delež vir so v podjetju zbrani ločeno.

3.B Delež recikliranih trdnih odpadkov.

3.C Destinacija ima uveden strateški pristop in zagotavlja monitoring na področju ravnanja s trdimi odpadki. Odpadki se ločujejo, predelujejo in reciklirajo. Destinacija ima zastavljene kvantitativne cilje za zmanjševanje količin trdnih odpadkov s poudarkom na zmanjševanju količin odpadne embalaže.

3.D Destinacija med obiskovalci promovira odgovorno ravnanje $\mathrm{z}$ odpadki ter jih motivira k ločenemu zbiranju odpadkov. Destinacija zagotavlja ustrezno število ločenih zbiralnikov.
$\mathrm{Da} / \mathrm{ne}$, Podjetje aktivno promovira Da/ne, priloži- politiko ravnanja z odpadki priložite do- in motivira goste k ločene- te dokazilo mu zbiranju odpadkov. kazilo

nja ter cilji in z indikatorji trajnostnega razvoja. Koordinator na sestanku pridobi povratne informacije o razpoložljivosti obstoječih ter možnostih pridobitve dodatnih podatkov, potrebnih za spremljanje trajnostnega razvoja. Prav tako je vloga koordinatorja, da doseže dogovor o ciljno usmerjenem delovanju vseh članov ekipe. 
Preglednica 2.6 Nadaljevanje s prejšnje strani

\begin{tabular}{|c|c|c|c|c|}
\hline \multicolumn{2}{|c|}{ Področje/indikator za destinacije } & (1) & Indikator za ponudnike & (1) \\
\hline \multicolumn{5}{|c|}{ 4. Ravnanje $z$ vodo } \\
\hline 4.A & $\begin{array}{l}\text { Delež odplak iz destinacije, } \\
\text { ki se pred odvajanjem pre- } \\
\text { čistijo (vsaj do sekundarne } \\
\text { stopnje).* }\end{array}$ & $\begin{array}{l}\text { Delež, } \\
\text { vir }\end{array}$ & $\begin{array}{l}\text { Delež odplak v podjetju, ki } \\
\text { se pred odvajanjem preči- } \\
\text { stijo (vsaj do sekundarne } \\
\text { stopnje). }\end{array}$ & Delež \\
\hline 4.B & $\begin{array}{l}\text { Ravnanje z odpadnimi vo- } \\
\text { dami je ustrezno urejeno } \\
\text { in regulirano na način, da } \\
\text { so vplivi na ljudi in okolje } \\
\text { čim manjši. }\end{array}$ & $\begin{array}{l}\text { Da/ne, } \\
\text { priloži- } \\
\text { te do- } \\
\text { kazilo }\end{array}$ & & \\
\hline 4.C & $\begin{array}{l}\text { Destinacija ustrezno upra- } \\
\text { vlja z vodnimi viri ter } \\
\text { spremlja porabo vode. Za- } \\
\text { gotavlja, da poraba vode } \\
\text { v turističnih podjetjih ne } \\
\text { ogroža potreb lokalnega } \\
\text { prebivalstva. Destinacija } \\
\text { spodbuja podjetja k racio- } \\
\text { nalni rabi vode. }\end{array}$ & $\begin{array}{l}\text { Da/ne, } \\
\text { priloži- } \\
\text { te do- } \\
\text { kazilo }\end{array}$ & $\begin{array}{l}\text { Podjetje ima sprejete ukre- } \\
\text { pe za zmanjševanje porabe } \\
\text { vode ter izvaja monitoring } \\
\text { nad porabo vode. }\end{array}$ & $\begin{array}{l}\mathrm{Da} / \text { ne, } \\
\text { priloži- } \\
\text { te do- } \\
\text { kazilo }\end{array}$ \\
\hline 4.D & $\begin{array}{l}\text { Destinacija promovira in } \\
\text { motivira obiskovalce k } \\
\text { zmanjševanju porabe vo- } \\
\text { de. }\end{array}$ & $\begin{array}{l}\text { Da/ne, } \\
\text { priloži- } \\
\text { te do- } \\
\text { kazilo }\end{array}$ & $\begin{array}{l}\text { Podjetje promovira politi- } \\
\text { ko odgovornega ravnanja } \\
\text { z vodo in motivira goste k } \\
\text { zmanjševanju porabe vode. }\end{array}$ & $\begin{array}{l}\mathrm{Da} / \text { ne, } \\
\text { priloži- } \\
\text { te do- } \\
\text { kazilo }\end{array}$ \\
\hline \multicolumn{5}{|c|}{ 5. Poraba energije in podnebne spremembe } \\
\hline 5.A & $\begin{array}{l}\text { Delež energije iz obnovlji- } \\
\text { vih virov. }\end{array}$ & $\begin{array}{l}\text { Delež, } \\
\text { vir }\end{array}$ & $\begin{array}{l}\text { Delež energije iz obnovlji- } \\
\text { vih virov. }\end{array}$ & $\begin{array}{l}\text { Delež, } \\
\text { vir }\end{array}$ \\
\hline 5.B & $\begin{array}{l}\text { Proizvodnja energije iz ob- } \\
\text { novljivih virov na prebival- } \\
\text { ca. }\end{array}$ & $\begin{array}{l}\text { Število, } \\
\text { vir }\end{array}$ & & \\
\hline
\end{tabular}

Nadaljevanje na naslednji strani

\section{3. korak: Zbiranje in pošiljanje podatkov}

Večino podatkov, potrebnih za izvedbo certificiranja in podelitev okoljskega znaka, je potrebno pridobiti neposredno od članov zelene ekipe. Zbiranje podatkov mora biti relativno preprosto ter mora omogočati združevanje različnih virov podatkov na enem mestu. Obdelani podatki podajo podrobno sliko o stanju in trajnostnem razvoju. Z namenom zbiranja podatkov je izdelan predhodno predstavljeni vprašalnik. Vprašalnik je smiselno opremiti s standardiziranim podpornim dokumentom, $v$ katerem so podane kratke smernice za lažjo evalvacijo vprašanj in definiranje bodočih aktivnosti 
Preglednica 2.6 Nadaljevanje s prejšnje strani

\begin{tabular}{|c|c|c|c|c|}
\hline \multicolumn{2}{|c|}{ Področje/indikator za destinacije } & \multirow{2}{*}{$\begin{array}{l}\text { (1) } \\
\text { Da/ne, } \\
\text { priloži- } \\
\text { te do- } \\
\text { kazilo }\end{array}$} & \multirow[t]{2}{*}{ Indikator za ponudnike } & \multirow[t]{2}{*}{$(1)$} \\
\hline 5.C & $\begin{array}{l}\text { Destinacija namenja ustre- } \\
\text { zno pozornost prilagajanju } \\
\text { na podnebne spremembe, } \\
\text { pri čemer posebno pozor- } \\
\text { nost namenja obalnim ob- } \\
\text { močjem. }\end{array}$ & & & \\
\hline 5.D & $\begin{array}{l}\text { V destinaciji obstajajo } \\
\text { ustrezni ukrepi in spodbu- } \\
\text { de za zmanjševanje odvi- } \\
\text { snosti od fosilnih goriv ter } \\
\text { večanje rabe obnovljivih } \\
\text { virov energije. }\end{array}$ & $\begin{array}{l}\mathrm{Da} / \text { ne, } \\
\text { priloži- } \\
\text { te do- } \\
\text { kazilo }\end{array}$ & $\begin{array}{l}\text { Podjetje ima uvedeno stra- } \\
\text { tegijo zmanjševanja pora- } \\
\text { be energije, spremlja pora- } \\
\text { bo energije ter zmanjšuje } \\
\text { svojo odvisnost od fosilnih } \\
\text { goriv. }\end{array}$ & $\begin{array}{l}\text { Da/ne, } \\
\text { priloži- } \\
\text { te do- } \\
\text { kazilo }\end{array}$ \\
\hline $5 . \mathrm{E}$ & $\begin{array}{l}\text { Destinacija turistična pod- } \\
\text { jetja spodbuja k ustrezne- } \\
\text { mu spremljanju, zmanjše- } \\
\text { vanju in javnemu poroča- } \\
\text { nju o porabi energije in iz- } \\
\text { pustih toplogrednih plinov. }\end{array}$ & $\begin{array}{l}\mathrm{Da} / \text { ne, } \\
\text { priloži- } \\
\text { te do- } \\
\text { kazilo }\end{array}$ & $\begin{array}{l}\text { Podjetje spremlja, zmanj- } \\
\text { šuje in javno poroča o po- } \\
\text { rabi energije in izpustih to- } \\
\text { plogrednih plinov. }\end{array}$ & $\begin{array}{l}\text { Da/ne, } \\
\text { priloži- } \\
\text { te do- } \\
\text { kazilo }\end{array}$ \\
\hline $5 . \mathrm{F}$ & $\begin{array}{l}\text { Destinacija promovira in } \\
\text { motivira obiskovalce za } \\
\text { zmanjševanje porabe ener- } \\
\text { gije. }\end{array}$ & $\begin{array}{l}\mathrm{Da} / \text { ne, } \\
\text { priloži- } \\
\text { te do- } \\
\text { kazilo }\end{array}$ & $\begin{array}{l}\text { Podjetje promovira politi- } \\
\text { ko zmanjševanja porabe } \\
\text { energije ter goste motivira } \\
\text { za zmanjševanju porabe. }\end{array}$ & $\begin{array}{l}\text { Da/ne, } \\
\text { priloži- } \\
\text { te do- } \\
\text { kazilo }\end{array}$ \\
\hline
\end{tabular}

Nadaljevanje na naslednji strani

(enako predlogo naj uporablja tudi regionalni evalvator). Zeleni koordinator deluje kot kontaktna točka za primerjavo podatkov, ki jih zbere zelena ekipa. Koordinator je prav tako odgovoren za izpolnjevanje vprašalnika, njegovo evalvacijo ter oblikovanje predloga ukrepov.

\section{4. korak: Analiza podatkov in (ne)izpolnjevanje pogojev za pridobitev okoljskega znaka}

Zeleni koordinator preliminarno obdelane podatke posreduje regionalnemu koordinatorju oz. koordinacijskemu odboru, ki izdela in poda končno evalvacijsko poročilo oz. oceno. Regionalni koordinator, poleg izpolnjenih vprašalnikov, prejme tudi dodatno dokumentacijo (dokazila).

Za potrebe analize podatkov, pridobljenih iz destinacij in podjetij, je kot dopolnitev vprašalnika pripravljena tudi predloga, ki služi kot pomoč pri odločanju. Destinacije in podjetja, ki zaprosijo za po- 
Preglednica 2.6 Nadaljevanje s prejšnje strani

\begin{tabular}{|c|c|c|c|c|}
\hline \multicolumn{2}{|c|}{ Področje/indikator za destinacije } & (1) & Indikator za ponudnike & (1) \\
\hline \multicolumn{5}{|c|}{ 6. Mehka (trajnostna) mobilnost } \\
\hline 6.A & $\begin{array}{l}\text { Destinacija ima izdelano } \\
\text { strategijo mehke mobilno- } \\
\text { sti, v kateri so opredeljeni } \\
\text { ukrepi za zmanjševanje ne- } \\
\text { gativnih vplivov transporta } \\
\text { in turizma na destinacijo. } \\
\text { Destinacija spodbuja peša- } \\
\text { čenje in kolesarjenje ter za- } \\
\text { gotavlja (gradi in vzdržuje) } \\
\text { ustrezno infrastrukturo. }\end{array}$ & $\begin{array}{l}\text { Da/ne, } \\
\text { priloži- } \\
\text { te do- } \\
\text { kazilo }\end{array}$ & & \\
\hline $6 . \mathrm{B}$ & $\begin{array}{l}\text { Število točk (mest) za iz- } \\
\text { posojo koles, e-koles, elek- } \\
\text { tričnih koles ter javnih ele- } \\
\text { ktričnih polnilnic. }\end{array}$ & $\begin{array}{l}\text { Število, } \\
\text { vir }\end{array}$ & $\begin{array}{l}\text { Podjetje ponuja/omogoča } \\
\text { izposojo koles, e-koles, ele- } \\
\text { ktričnih koles ter zagota- } \\
\text { vlja možnost polnjenja ba- } \\
\text { terij vozil na električni po- } \\
\text { gon ali promovira podjetja, } \\
\text { ki navedene storitve nu- } \\
\text { dijo. Podjetje tovrstno po- } \\
\text { nudbo vključuje v svoje tu- } \\
\text { ristične proizvode. }\end{array}$ & $\begin{array}{l}\text { Da/ne, } \\
\text { priloži- } \\
\text { te do- } \\
\text { kazilo }\end{array}$ \\
\hline 6.C & $\begin{array}{l}\text { Destinacija promovira in } \\
\text { obiskovalce motivira k } \\
\text { uporabi mehke mobilnosti. }\end{array}$ & $\begin{array}{l}\text { Da/ne, } \\
\text { priloži- } \\
\text { te do- } \\
\text { kazilo }\end{array}$ & $\begin{array}{l}\text { Podjetje promovira mehko } \\
\text { mobilnost ter goste motivi- } \\
\text { ra za njeno uporabo. }\end{array}$ & $\begin{array}{l}\text { Da/ne, } \\
\text { priloži- } \\
\text { te do- } \\
\text { kazilo }\end{array}$ \\
\hline
\end{tabular}

Opombe (1) Vrednost/dokazilo. Povzeto po Apih in Ramos (2018), Novak idr. (2015) in Global Sustainable Tourism Council (https://www.gstcouncil.org).

delitev okoljskega znaka, ${ }^{36}$ morajo izpolnjevati vsaj $65 \%$ vseh kriterijev. Točkovalnika za posamezne indikatorje nismo oblikovali, vendar predlagamo enakomerno razporeditev točk med posameznimi skupinami atributov. Poročilo s priporočili in sklep se posredujeta posameznemu zelenemu koordinatorju.

\section{5. korak: Opredelitev prednostnih aktivnosti in določitev akcijskega načrta}

Ko zeleni koordinator prejme revizijsko poročilo, je odgovoren za pripravo akcijskega načrta. Koordinator organizira srečanje zelene

36. Predloga okoljskega znaka ne podajamo, vendar predlagamo, da naj ta smiselno poudari značilnosti lokalnega okolja (v logotipu je smiselno zajeti elemente, kot so morje, soline, galebi, istrska koza itd.). 
Preglednica 2.7 Predlagani časovni okvir za izvedbo certifikacijskega postopka

\begin{tabular}{ll}
\hline Meseci & Koraki \\
\hline 1 & $\begin{array}{l}\text { Vloga za pričetek postopka. } \\
\text { Izvedba informativnih izobraževalnih delavnic. }\end{array}$ \\
\hline $1-3$ & Dvig zavesti \\
\hline $1-3$ & $\begin{array}{l}\text { Določitev zelenega koordinatorja. } \\
\text { Oblikovanje zelene ekipe. } \\
\\
\end{array} \quad \begin{array}{l}\text { Določitev vlog in odgovornosti. } \\
\text { Izvedba uvodnih srečanj. }\end{array}$ \\
\hline $3-9$ & $\begin{array}{l}\text { Zbiranje podatkov. } \\
\text { Posredovanje podatkov regionalnemu koordinatorju/evalvatorju. }\end{array}$ \\
\hline $9-11$ & $\begin{array}{l}\text { Potek evalvacijskega postopka s strani regionalnega koordinator- } \\
\text { ja/evalvatorja. }\end{array}$ \\
\hline 12 & Poročilo s priporočili. \\
\hline $12-15$ & $\begin{array}{l}\text { Opredelitev prednostnih aktivnosti in določitev akcijskega načrta. } \\
\text { Posredovanje akcijskega načrta regionalnemu koordinatorju. }\end{array}$ \\
\hline $12-15$ & Permanentna izobraževanja. \\
\hline 36 & Ponovna evalvacija. \\
\hline
\end{tabular}

Opombe Povzeto po Apih in Ramos (2018).

ekipe, ki pregleda in analizira rezultate, oblikuje realne (merljive in dosegljive) cilje ter se dogovori o načinu doseganja le-teh. Zelena ekipa prav tako odloči, katera področja zahtevajo prednostno obravnavo. Pripravljen akcijski načrt zeleni koordinator posreduje regionalnemu koordinatorju oz. odboru. $V$ primeru negativnega izida lahko zeleni koordinator, po sprejemu ustreznih ukrepov, zaprosi za izredno evalvacijo.

\section{6. korak: Povratna zanka - stalni razvoj in izboljšave}

Priporočljivo je, da zeleni koordinator vsako leto pripravi poročilo o napredku in ga posreduje regionalnemu koordinatorju, ki bdi nad stanjem na terenu in skrbi za izvedbo regionalnih izobraževanj. Redna evalvacija ponudnikov se izvaja vsaka tri leta, pri čemer je pri vsakem naslednjem ocenjevanju odstotek ustreznosti potrebno zvišati na najmanj $5 \%$. V preglednici 2.7 predstavljamo teoretični časovni okvir, ki je potreben za izvedbo certifikacijskega postopka

\section{Zaključek}

V prispevku smo predstavili predlog certifikacijske sheme za Mediteransko Slovenijo, s katerim želimo predvsem spodbuditi trajnosti 
razvoj destinacije. Kljub dejstvu, da zsst pridobiva na globalnem pomenu, je njena implementacija na lokalni ravni relativno slaba. S predlogom nove in prilagojene sheme želimo različne deležnike vzpodbuditi k razmisleku o pomenu in podpori trajnostnega razvoja turizma. Pri tem je ključno zavedanje, da je za vzpostavitev trajnostne destinacije potrebno veliko dela, promocije in vztrajnosti, pri čemer igra ključno vlogo podpora lokalnih oblasti. Posledično predlagamo, da se pri regionalnem razvoju oblikuje zelena ekipa, ki bo vztrajno promovirala koncept trajnosti. Za uspešen razvoj trajnostnega turizma niso odgovorni zgolj politika in ponudniki, temveč vsi deležniki na vseh področjih družbenega delovanja. Ključnega pomena so seveda prebivalci, saj mora biti destinacija "trajnostna" predvsem zanje, šele nato pa za posameznike in podjetja, ki v njej delajo, ter turiste in obiskovalce.

Predlagamo, da prihodnje raziskave vključujejo tudi nabor primarnih podatkov, na osnovi katerih bi lahko preučili tudi odnos različnih skupin deležnikov do trajnostnega razvoja kot tudi različne vidike trajnosti (npr. okoljski vidik s poudarkom na mobilnosti, gospodarski vidik s poudarkom na vključevanju lokalnih dobrin v turistično ponudbo in podaljševanju turistične sezone, družbeno-kulturni vidik s poudarkom na vključevanju dediščine v turistično ponudbo itd.). Turistični ponudniki morajo stremeti k razvoju zelenih turističnih proizvodov ter postopnemu vstopu v zsst. Menimo, da nova shema predstavlja prispevek $\mathrm{k}$ nadaljnjemu razvoju trajnostnega turizma na območju Mediteranske Slovenije, prav tako pa lahko koristi tudi drugim destinacijam, ki se odločajo za razvoj trajnostnega turizma.

Za načrtno uveljavljanje trajnostnega razvoja turizma je prav tako pomembno pravočasno in celovito prostorsko načrtovanje, ki v svojih razvojnih strategijah načrtovane posege umešča v prostor. Svetovna turistična organizacija (UNWTO) in Program Združenih narodov za okolje (UNEP) poleg celovitega prostorskega načrtovanja regij in usklajenega upravljanja turističnih destinacij priporočata tudi izdelavo analize nosilne zmogljivosti za posamezne turistične destinacije. Analiza nosilne zmogljivosti omogoča opredelitev maksimalnega števila obiskovalcev, ki lahko hkrati obiščejo posamezno destinacijo, ne da bi pri tem povzročili trajne in nesprejemljive posledice za prostor, ekološko in socio-ekonomsko okolje. Metoda analize nosilne zmogljivosti se je v mednarodni praksi izkazala kot ustrezen pri- 
pomoček za preprečevanje prenasičenosti turističnih destinacij (Vodeb, 2014).

\section{Literatura}

Apih, J., in Ramos, H. (2018). Qnest quality brand for sustainable environment (Elaborat). Univerza na Primorskem, Portorož.

Basu, P. K. (2017). Is sustainable tourism development possible? Broad issues concerning Australia and Papua New Guinea. V R. N. Ghosh in M. A. B. Siddique (ur.), Tourism and Economic Development (str. 140-149). London: Routledge.

Bitenc, S. (2017). Vključevanje destinacije v zeleno shemo slovenskega turizma? Primer Kamnika (Neobjavljeno magistrsko delo). Ekonomska fakulteta, Ljubljana.

Cheng, T.-M., in Wu, H. C. (2015). How do environmental knowledge, environmental sensitivity, and place attachment affect environmentally responsible behavior? An integrated approach for sustainable island tourism. Journal of Sustainable Tourism, 23(4), 557-576.

Din, K. H. (2018). Dialogue with the hosts: An educational strategy towards sustainable tourism. V M. Hitchcock, V. T. King in M. J. G. Parnwell (ur.), Tourism in South-East Asia (str. 345-354). London: Routledge.

Dwyer, L. (2005). Relevance of triple bottom line reporting to achievement of sustainable tourism: A scoping study. Tourism Review International, 9(1), 79-938.

Evropska komisija. (2010). Evropa, prva svetovna turistična destinacijanov okvir evropske turistične politike (сом(2010) 352 konč.). Bruselj: Evropska komisija.

Evropski Parlament in Svet Evropske unije. (2008). Direktiva 2008/56/ES Evropskega Parlamenta in Sveta z dne 17. junija 2008 o določitvi okvira za ukrepe Skupnosti na področju politike morskega okolja. Uradni list Evropske unije, L 164/19-40.

Font, X., in Buckley, R. (2001). Tourism ecolabelling: Certification and promotion of sustainable management. Wallingford: CABI.

Galič, L. (2013). Analiza indikatorjev trajnostnega razvoja turističnih destinacij na primeru Slovenije (Neobjavljeno magistrsko delo). Ekonomska fakulteta, Ljubljana.

Glasbergen, P., in Driessen, P. P. (2002). The paradigm shift in environmental politics. V P. P. J. Driessen in P. Glasbergen (ur.), Greening Society (str. 3-25). Dordrecht: Springer.

Jamal, T., in Camargo, B. A. (2014). Sustainable tourism, justice and an ethic of care: Toward the just destination. Journal of Sustainable Tourism, 22(1), 11-30. 
Juvan, E., in Dolnicar, S. (2014). The attitude-behaviour gap in sustainable tourism. Annals of Tourism Research, 48, 76-95.

Metelko, U. (2014). Družbeno odgovorni sonaravni turizem v Sloveniji. Revija za univerzalno odličnost, 3(2), 77-86.

Mihalic, T. (2016). Sustainable-responsible tourism discourse: Towards 'responsustable' tourism. Journal of Cleaner Production, 111, 461-470.

Mihalič, T. (2006). Tourism and its environments: Ecological, economic and political sustainability issues. Ljubljana: Ekonomska fakulteta.

Ministrstvo za gospodarski razvoj in tehnologijo. (2017). Strategija trajnostne rasti slovenskega turizma 2017-2021. Pridobljeno s http:// www.mgrt.gov.si/fileadmin/mgrt.gov.si/pageuploads/Strategija _turizem_koncno_5.10.2017.pdf

Ministrstvo za gospodarstvo. (2006). Program ekološke ureditve in posodobitve slovenskih hotelov (Elaborat). Ministrstvo za gospodarstvo, Ljubljana.

Ministrstvo za okolje in prostor. (2007). Priporočila ministra za pripravo občinskih programov varstva okolja. Ljubljana: Ministrstvo za okolje in prostor.

Mulej, M. (2012). Temelji družbeno odgovornega ravnanja pri uveljavljanju univerzalne odličnosti in mojstrstva. V B. Bukovec (ur.), 24. Forum odličnosti in mojstrstva: Družbeno odgovorno ravnanje pri uveljavljanju univerzalne odličnosti in mojstrstva (str. 5-34). Novo mesto: Fakulteta za organizacijske študije v Novem mestu.

Notarstefano, C. 2007. European sustainable tourism: Context, concepts and guidelines for action. Pridobljeno s http://www .turismoycooperacion.org/OBSERTUR/E/o2.pdf

Novak, M., Apih, J., Zakonjšek, T., Klavora, J., Brezovec, A., in Križaj, D. (2015). Zelena shema slovenskega turizma: priročnik za destinacije in ponudnike (Elaborat). Univerza na Primorskem, Portorož.

Omerzel Gomezel, D. (2016). Sustainable tourism business: An introduction to the thematic issue. Managing Global Transitions, 14(1), 3.

Sasidharan, V., in Križaj, D. (2018). Tourism ecolabels and social sustainability: Challenges and Innovations from a Slovene Perspective. Academica Turistica, 11(1), 19-29.

Slovenska turistična organizacija. (2018). Zelena shema slovenskega turizma. Pridobljeno s https://www.slovenia.info/sl/poslovne-strani/ zelena-shema-slovenskega-turizma

United Nations. (2018). Progress report on the 10-year framework of programmes on sustainable consumption and production patterns. Pridobljeno s http://cf.cdn.unwto.org/sites/all/files/docpdf/e20186oen.pdf

United Nations Environment Programme in World Tourism Organizati- 
on. (2018). Making tourism more sustainable: A guide for policy makers. Pariz: United Nations Environment Programme; Madrid: World Tourism Organization.

Vodeb, K. (2014). Turistična destinacija: sodobna obravnava koncepta. Koper: Založba Univerze na Primorskem.

Weaver, D. B. (2006). Sustainable tourism: Theory and practice. Oxford: Elsevier.

World Tourism Organization. (1996). What tourism managers need to know: A practical guide to the development and use of indicators of sustainable tourism. Madrid: World Tourism Organization.

World Tourism Organization. (2004). Indicators of sustainable development for tourism destinations: A Guidebook. Madrid: World Tourism Organization.

Zakon o spodbujanju razvoja turizma (zsRT-1). (2018). Uradni list Republike Slovenije, št. 13.

Zorko, D. (1999). Uvod v turizem. Ljubljana: Biro M. 
Družbena odgovornost:

pogledi deležnikov na delovanje

turističnih podjetij v Občini Piran

\section{Tanja Planinc in Zorana Medarić}

V prispevku predstavljamo manj raziskan vidik družbene odgovornosti hotelskih podjetij, natančneje, socialni vidik družbene odgovornosti, ki se nanaša na odnos do lokalne skupnosti v Občini Piran. Pri tem izhajamo iz splošno sprejete delitve družbene odgovornosti na ekonomski, okoljski in socialni vidik. Nanjo vpliva predvsem koncept trajnosti, ki je opredeljen prav s temi tremi stebri. Kot pravi Lund-Durlacher (2015), lahko namreč družbeno odgovornost s preprostimi besedami opredelimo prav kot prispevek k trajnostnemu razvoju. Število raziskav, ki preučujejo družbeno odgovornost v podjetjih, v zadnjih desetletjih narašča, vendar so zlasti socialni vidiki družbene odgovornosti podjetij v hotelirstvu slabo raziskani (Coles, Fenclova in Dinan, 2013). To gre v veliki meri pripisati dejstvu, da je odločitev podjetij za družbeno odgovorno delovanje še vedno pogosto tesno povezana z ekonomskimi motivi (Barney, 2001; Branco in Rodrigues, 2006). Socialna vidika družbene odgovornosti podjetij skrb za zaposlene in lokalno skupnost - pa sta manj prepoznana kot ekonomsko učinkovita v primerjavi z drugimi vidiki. Hotelska podjetja se tako npr. raje usmerjajo v skrb za okolje, saj jim prinaša neposredne in hitrejše ekonomske koristi. Levy in Park (2011) s tem v zvezi ugotavljata, da v okviru družbene odgovornosti v hotelski industriji še zmeraj prevladujejo "zelene« prakse, kot sta ponovna uporaba 
brisač in posteljnine ter vgradnja energetsko učinkovitejših sistemov oziroma sistemov za učinkovitejšo porabo vode, ki prinašajo neposredne pozitivne finančne učinke.

V zadnjem desetletju pa se vendarle pogosteje pojavljajo prakse in raziskave, ki se osredotočajo tudi na socialne vidike družbene odgovornosti v hotelskih podjetjih, kot je odnos do zaposlenih oziroma do lokalne skupnosti (Kasim, 2004, 2006; Bohdanowicz in Zientara, 2008a, 2008b; Skudiene in Auruskeviciene, 2012; Levy in Park, 2011; De Grobois, 2012; Abaeian, Yeoh in Khong 2014; Kim, Rhou, Uysal in Kwon 2017; Mohammed in Rashid, 2018).

\section{Koncept družbene odgovornosti}

\section{Razumevanje družbene odgovornosti podjetij}

Družbena odgovornost podjetij ni nova tema; vprašanja odgovornosti podjetij se pojavljajo vse od 30. let prejšnjega stoletja (Caroll, 1979), v zadnjem desetletju pa je ta tema doživela posebej izrazit razmah. Ena izmed pogosteje navajanih definicij je zagotovo Carollova (1979), ki pravi, da moramo, če želimo zajeti široko paleto družbene odgovornosti podjetij, upoštevati štiri vidike odgovornosti, in sicer ekonomskega, zakonskega, etičnega in diskrecijskega (kasneje filantropskega). Pri prvem gre za temeljno razumevanje podjetij kot ekonomskih enot, ki ustvarjajo in prodajajo dobrine in storitve, ki jih družba želi. Zakonska odgovornost podjetja pomeni, da morajo podjetja svojo dejavnost opravljati v okviru zakonskih regulativ. Etična odgovornost je ohlapneje definirana, vendar pomeni zavezanost etičnim normam družbenega konteksta, v katerem podjetja delujejo, in torej pričakovanju, da bodo delovala skladno z njimi. Zadnji vidik odgovornosti pa je tisti, katerega družbene smernice niso jasno definirane in za katerega se podjetja odločajo sama; gre za prevzemanje prostovoljnih družbenih vlog podjetij, ki so sicer pričakovane, ne pa tudi natančno opredeljene, kot npr. sodelovanje pri lokalnih prireditvah, dodatna skrb za zaposlene in podobno.

Sorodnih definicij pojma družbene odgovornosti je veliko, pravzaprav gre za izjemno široko področje, ki se je skozi desetletja zelo spreminjalo. Podobno kot Carollova se različne definicije (Dahlsrud (2008) jih analizira kar 37) nanašajo na zelo različna področja, ki naj bi jih družbena odgovornost zajemala. Dahlsrud navede naslednja ključna področja oziroma dimenzije družbene odgovornosti: okoljsko, socialno, ekonomsko, deležniško in vidik dobrodelnosti. 
Shafiqur (2011) jih navede kar deset, in sicer: obveznosti do družbe, vključevanje deležnikov, izboljšanje kakovosti življenja, gospodarski razvoj, etična poslovna praksa, upoštevanje zakonodaje, prostovoljstvo, človekove pravice, varstvo okolja, transparentnost in odgovornost. Hamidu, Haron, in Azlan (2015), ki so opravili pregled definicij skozi čas, ugotavljajo, da se te s časom spreminjajo. Zgodnje definicije (1950-1960) izpostavljajo predvsem družbeno odgovornost, ki $\mathrm{s}$ pomočjo človekoljubnih aktivnosti in prostovoljstva pripomore $\mathrm{k}$ družbenemu blagostanju in razvoju. Naslednji sklop (1970-1980) je usmerjen $\mathrm{v}$ vse večje zavedanje delavskih pravic ter pomena zadovoljstva deležnikov in upravljanja odnosov, reguliranja praks družbene odgovornosti in varstva potrošnikov. Zadnje obdobje (od 1990 do danes) pa raziskovalci opredelijo kot obdobje instrumentalnosti in trajnosti.

V sedanjem času pogosto naletimo tudi na zelo splošne definicije, kot je npr. definicija Evropske komisije, ki družbeno odgovornost opredeljuje kot (2013, str. 6) »odgovornost podjetij za njihove učinke na družbo«, pri čemer so izpostavljeni trije vidiki - okoljska vprašanja, etična vprašanja ter vprašanja človekovih pravic in potrošniška vprašanja -, ki morajo biti vključeni v poslovanje podjetij in njihovo strategijo. Pomembno pa je, da taka definicija poudarja večrazsežnostno naravo družbene odgovornosti, ki naj bi zajemala najmanj naslednje vidike (str. 6): „človekove pravice, delovne in zaposlovalne prakse (npr. usposabljanje, različnost, enakost spolov ter zdravje in blagostanje zaposlenih), okoljska vprašanja (biotska raznovrstnost, podnebne spremembe, učinkovitost virov, ocena življenjskega cikla in preprečevanje onesnaževanja) ter boj proti podkupovanju in korupciji. Del načrta družbene odgovornosti so tudi vključenost in razvoj skupnosti, vključevanje invalidnih oseb ter interesi potrošnikov, vključno z zasebnostjo. Med pomembna skupna vprašanja spadata tudi spodbujanje družbene in okoljske odgovornosti v dobavni verigi ter razkrivanje nefinančnih informacij. Komisija je sprejela sporočilo o politikah Eu in prostovoljstvu, v katerem priznava prostovoljno udejstvovanje zaposlenih kot izraz družbene odgovornosti.«

Narava koncepta družbene odgovornosti je tako zelo široka in zajema številne vidike. Skudiene in Auruskeviciene (2012), ki prav tako poudarjata večdimenzionalno naravo tega koncepta, ločujeta med notranjimi in zunanjimi aktivnostmi družbene odgovornosti, pri čemer zunanje opredelita kot odgovorno obnašanje do zunanjih dele- 
žnikov, kot so potrošniki, lokalna skupnost in poslovni partnerji. V nadaljevanju nas bo zanimal predvsem vidik družbene odgovornosti, ki se nanaša na vključenost in razvoj lokalne skupnosti.

\section{Družbena odgovornost $v$ hotelskih podjetjih in lokalna skupnost}

V turistični industriji je prav hotelski sektor tisti, ki je v veliki meri vpet v lokalno okolje; $\mathrm{z}$ njim je neizogibno povezan in obenem odvisen od družbe, v kateri deluje (Abaeian idr., 2014). Zato ni presenetljivo, da so bile hotelske verige pogosto ene prvih, ki so pričele uvajati pobude in politike družbene odgovornosti (Kasim, 2006). Število raziskav, ki se ukvarjajo z vprašanjem družbene odgovornosti v turizmu, se je v zadnjih petnajstih letih zelo povečalo (Farrington, Curran, Gori, O'Gorman in Queenan, 2017), kljub temu pa je raziskav, ki bi se ukvarjale s področjem družbene odgovornosti v hotelskih podjetjih in turizmu nasploh, razmeroma malo. Malo je zlasti raziskav, ki bi se ukvarjale z odnosom hotelskih podjetij do lokalne skupnosti (Chen in Lin, 2015; de Miguel Molina, de Miguel Molina, Segarra Oña in Peiró Signes, 2018).

Obstoječe študije se osredotočajo predvsem na tri makro teme implementacijo družbene odgovornosti, ekonomsko utemeljevanje družbene odgovornosti ter socialne odnose in družbeno odgovornost (Coles idr., 2013). Del študij, ki se nanašajo na vidik implementacije, se usmerja tudi v identifikacijo praks družbene odgovornosti v hotelskih podjetjih (Kasim, 2007; Bohdanowicz in Zientara, 2008; Levy in Park, 2011; de Grosbois, 2012; Park in Levy, 2014). Levy in Park (2011) sta na primeru zDA preučila, katere so ključne prakse družbene odgovornosti, ki jih vpeljujejo v hotelskih podjetjih; ugotavljata, da prevladujejo okoljsko usmerjene prakse. Kljub temu navajata tudi kar nekaj praks, ki se nanašajo na socialne vidike družbene odgovornosti, kot npr.: donacije lokalni skupnosti v obliki denarja ali produktov, organizacija/sponzorstvo dogodkov z namenom zbiranja sredstev, ocena potencialnih družbenih vplivov na skupnost in iskanje možnosti za njihovo upravljanje pred samo izgradnjo hotela, članstvo v mednarodni organizaciji, ki spodbuja odgovorno poslovanje, vpeljevanje kodeksa ravnanja dobaviteljev/smernic za etične standarde ali standarde človekovih pravic, zmanjševanje porabe lokalnih virov v hotelih $\mathrm{z}$ namenom preprečevanja izčrpanja virov, omogočanje zaposlenim, da se prostovoljno vključujejo v skupnost $\mathrm{z}$ ustreznimi prispevki dobrodelnim organizacijam in/ali razvoj omrežij z 
lokalnimi organizacijami ter zagotavljanje možnosti, da gostje dajejo prostovoljne prispevke ali kot prostovoljci sodelujejo z lokalnimi organizacijami.

V prispevku iz leta 2014 Park in Levy še poudarjata, da bi se morali hotelski managerji osredotočati tudi na pobude družbene odgovornosti, ki se usmerjajo v skupnost, zaposlene in goste. Bohdanowicz in Zientara (2008) v tem kontekstu izpostavljata, da imajo lahko hotelska podjetja zelo pomembno vlogo pri razvoju lokalnih skupnosti. Preučevala sta odnos hotelskih podjetij do zaposlenih, vendar ju je zanimal tudi širši vidik odnosa do lokalne skupnosti, ki postaja v zadnjih letih vse pomembnejša dimenzija družbene odgovornosti podjetij. Ugotavljata, da so politike družbene odgovornosti danes obvezen del hotelirstva, predvsem mednarodnih korporacij, pri čemer se izboljšuje tudi dejansko izvajanje tovrstnih politik. Navajata primer skandinavske verige Scandic, ki prednjači na tem področju, saj vprašanja družbene odgovornosti upošteva pri vseh korporativnih odločitvah. Izboljšanje položaja zaposlenih in pozitivni vplivi v lokalnih okoljih, v katerih hoteli delujejo, so torej del strategije te hotelske verige. Donacije, vključevanje v delo lokalnih skupnosti in kupovanje dobrin iz pravične trgovine so pobude, ki prevladujejo med 13 večjimi hotelskimi znamkami, ki sta jih preučevala raziskovalca. Pri tem poudarjata, da je dobrodelnost kot pobuda, ki je bila najpogosteje identificirana pri hotelskih podjetjih, sicer pomembna, ne sme pa biti najpomembnejša oziroma edina. Zelo pomembno je vključevati zaposlene in jih osveščati o pomenu skrbi za lokalno skupnost, saj zgolj to prinaša dolgoročne koristi za vse. Videti je namreč, da pobude, ki kažejo, da hotelskim podjetjem ni vseeno za svoje zaposlene - tako $\mathrm{z}$ vidika informiranja in ustreznega plačila kot tudi $\mathrm{z}$ vidika možnosti nadgrajevanja znanja ter izboljšanja zdravja oziroma življenjskega sloga -, zmanjšujejo težave na področju človeških virov v hotelirstvu.

V lokalno skupnost usmerjene aktivnosti družbene odgovornosti pripomorejo tudi $\mathrm{k}$ temu, da je turizem pripoznan kot pozitivna dejavnost, ki je v določenem okolju koristna za vse (Bohdanowicz in Zientara, 2008). V tem smislu se De Grosbois (2012) osredotoča na prakse družbene odgovornosti v ključnih svetovnih hotelskih podjetjih in izpostavi, da se številna podjetja deklarirajo kot družbeno odgovorna, pri čemer pa mnoga ne opredeljujejo konkretnih pobud oziroma uspehov tovrstnih praks. Okvir za identifikacijo praks pred- 
stavlja pet področij: okoljske cilje, zaposlitveno enakost, raznolikost in dostopnost, ekonomsko blaginjo ter družbeno in skupnostno dobrobit. Ker se v pričujočem prispevku osredotočamo prav na ta vidik, nas je zanimalo, katerim ciljem sledijo pobude, ki jih uvrščamo na to področje. Avtorica mednje šteje pobude, ki si prizadevajo za izboljšanje kakovosti življenja lokalne skupnosti, nudijo podporo mednarodnim/globalnim pobudam, se usmerjajo v zaščito dediščine, kulture ali tradicij, osveščajo ali se vključujejo v trajnostni razvoj, ponujajo odgovorne oziroma zdrave produktne izbire in ustvarjajo varno okolje za svoje goste. Čeprav, kot ugotavljata Sheldon in Park (2011), zanimanje za družbeno odgovornost podjetij narašča, je razumevanje politik družbene odgovornosti v hotelirstvu še pomanjkljivo.

V prispevku se bomo zato osredotočili na vprašanje, kako družbeno odgovornost hotelskih podjetij v navezavi na lokalno skupnost $\mathrm{v}$ Občini Piran zaznavajo: (1) zaposleni v hotelskih podjetjih, (2) vodstvo hotelskih podjetij, (3) stroka ter (4) snovalci in izvajalci turistične politike v Občini Piran. Pri tem nas bo zanimalo tako razumevanje družbene odgovornosti, identificirane prakse, kot tudi vidik sodelovanja med deležniki.

Glede na podatke Statističnega urada Republike Slovenije ${ }^{1}$ je Občina Piran turistično najrazvitejša slovenska občina. Leta 2017 so v njej zabeležili dobrih 530.000 turistov (domačih in tujih) ter skoraj 1,7 milijona nočitev. ${ }^{2}$ Najštevilčnejši (in posledično najpomembnejši) so italijanski, avstrijski, nemški in domači gostje. V občini je na voljo približno 14.500 ležišč, od katerih jih je skoraj polovica v hotelih in podobnih nastanitvenih obratih. Ravno hoteli in podobni nastanitveni obrati imajo največji tržni delež, saj so ustvarili tri četrtine prihodov. Turizem ima v občini izrazito sezonski značaj, saj se več kot polovica vseh nočitev realizira v poletnih mesecih (Lesjak, Brezovec in Fabjan, 2018). Z gospodarskega vidika je turizem v Občini Piran pomemben zaposlovalec - 19 gospodarskih družb, ki ima registrirano dejavnost hotelov in podobnih nastanitvenih obratov, je leta 2017 zaposlovalo 1.058 oseb, ki so imele povprečno bruto plačo 1.506 evrov. $^{3}$

1. Glej https://www.stat.si/obcine/sl/2014/Municip/Index/119.

2. Glej https://pxweb.stat.si/pxweb/Dialog/Saveshow.asp.

3. Glej https://www.ajpes.si/fipo/ag_prikaz.asp?id=15223457\&prikazTabele=3 \&LetoP=2016. 


\section{Metodologija}

Namen izvedbe empirične raziskave je bil preučiti socialni vidik družbene odgovornosti, ki se nanaša na odnos izbranih hotelskih podjetij do lokalnega okolja. Želeli smo preveriti, kako vidik družbene odgovornosti, ki se nanaša na odnos hotelskih podjetij do lokalnega okolja, zaznavajo snovalci in izvajalci turistične politike v Občini Piran, stroka ter vodstvo in zaposleni v izbranih hotelskih podjetjih. Za pridobivanje primarnih podatkov smo uporabili metodi, ki sta med seboj komplementarni, in sicer kvalitativno metodo intervjuvanja in kvantitativno metodo anketnega raziskovanja. $S$ pomočjo intervjuja smo preverjali, kakšen je odnos izbranih hotelskih podjetij do lokalnega okolja ter kako ta odnos zaznavajo snovalci in izvajalci turistične politike v Občini Piran ter stroka. Anketni vprašalnik smo uporabili pri preverjanju zaznavanja odnosa do lokalnega okolja med zaposlenimi v izbranih hotelskih podjetjih. S pomočjo triangulacije smo dobili celovitejši vpogled v obravnavano problematiko. Anketni vprašalnik in vprašanja za intervju so bili pripravljeni na osnovi predhodnih merskih instrumentov pri preučevanju družbene odgovornosti do zaposlenih idr.

Intervjuji z vodstvom izbranih hotelov, s snovalci in z izvajalci turistične politike v Občini Piran ter s stroko so bili opravljeni od julija do oktobra 2017. Opravljenih je bilo 9 polstrukturiranih intervjujev, ki so bili v soglasju z intervjuvanci v večini primerov zvočno posneti za potrebe transkripcije. Pripravljenih je bilo 13 okvirnih vprašanj, s pomočjo katerih smo želeli dobiti pogled deležnikov na družbeno odgovornost. Intervjuji so bili dolgi od 40 do 95 minut. Transkribirane intervjuje smo nato pregledali in ustrezno zakodirali za potrebe nadaljnje analize.

K sodelovanju v anketni raziskavi smo povabili vsa hotelska podjetja v Občini Piran. Našemu vabilu se je odzvalo 12 podjetij, preostala podjetja pa se sploh niso odzvala oziroma so sodelovanje zavrnila. Anketni vprašalnik za zaposlene smo oblikovali na podlagi že obstoječih in preverjenih spremenljivk, ki smo jih identificirali ob pregledu literature (Back, Lee in Abbot, 2011; Lux, Jex in Hansen, 1996; Carroll, 1979; Lee, Park in Lee, 2013). V tem poglavju bomo predstavili le del obsežnejšega vprašalnika, ki se je sicer nanašal na zaznavanje širšega socialnega vidika družbene odgovornosti v hotelskih podjetjih, in sicer le tisti del, ki se nanaša na odnos podjetja do lokalnega 
okolja. Vprašalnik je bil sestavljen iz več sklopov, in sicer v sledečem vrstnem redu:

- splošna vprašanja o anketirancu (delovno mesto, delovna doba v izbranem hotelskem podjetju in v celoti, vrsta zaposlitve),

- vprašanja o zaznavanju odnosa izbranega hotelskega podjetja do lokalnega okolja,

- demografska vprašanja o anketirancu (spol, starost, zaključena izobrazba).

Vprašalnik je sestavljalo 11 vprašanj, večina (8) jih je bila zaprtega tipa, 3 vprašanja pa so bila odprtega tipa. Uvodni del je vseboval namen, navodila za izpolnjevanje, zagotovilo o anonimnosti in zahvalo za sodelovanje. Trditve, vezane na vidik lokalnega okolja, obveščenost zaposlenih o vseh aktivnostih, ki jih izvaja hotelsko podjetje, $\mathrm{v}$ katerem so zaposleni, in pomembnost zaposlitve v podjetju, ki sodeluje pri razvoju lokalne skupnosti, so bile oblikovane kot mnenjska vprašanja s petimi trditvami, ki so jih anketiranci ocenjevali na simetrični petstopenjski ordinalni lestvici Likertovega tipa z nevtralno vrednostjo (1 pomeni »sploh ne drži«, 2 pomeni »ne drži«, 3 pomeni "niti niti«, 4 pomeni »drži« in 5 pomeni "popolnoma drži«). Pri ocenjevanju trditev, ki so se nanašale na odnos podjetja do lokalnega okolja, so lahko anketiranci izbrali tudi oceno "ne vem/ne morem odgovoriti«. Vprašalnik smo predhodno testirali na manjši skupini zaposlenih $\mathrm{v}$ hotelirstvu in ga na podlagi njihovih komentarjev nekoliko prilagodili. Anketiranje je potekalo od julija 2017 do maja 2018.

\section{Rezultati}

\section{Pogled deležnikov na družbeno odgovornost hotelskih podjetij in sodelovanje z lokalnim okoljem}

Najprej bomo predstavili, kako predstavniki hotelskih podjetij, turističnega združenja, občine in stroke opredeljujejo družbeno odgovornost. Zanimalo nas bo tudi, kako zaznavajo spreminjanje družbene odgovornosti na destinaciji skozi čas, kako vidijo sodelovanje z lokalnim okoljem in kateri so izzivi, ki jih zaznavajo na tem področju.

\section{Percepcija družbene odgovornosti}

Kako deležniki zaznavajo družbeno odgovornost in katere njene vidike izpostavljajo? Družbena odgovornost je med deležniki najpogo- 
steje opredeljena kot retribucija okolju, v katerega so vpeta hotelska podjetja. Razumljena je torej kot neke vrste povračilo podjetij, ker delujejo v določenem okolju, ki jim prinaša dobiček. Ta dobiček morajo torej deliti tako, da vlagajo v okolje.

Jaz jo razumem predvsem tako, da podjetje sodeluje z okoljem, da vrača v okolje del svojih profitov, da vključuje konkretno lokalna društva, da pomagajo, da so sponzorji, da jim pomagajo pri dogodkih, da jim dajejo razne popuste, nagrade za srečelove, tombole in podobne zadeve. Jaz vidim to $\mathrm{v}$ tem kontekstu. Kulturna društva - da jih podpirajo, da lahko izvajajo kulturno dejavnost, športna društva - pa tudi za športne prireditve. To pomeni, da imajo ta občutek vračanja v okolje. To je zame družbeno odgovorno. [Predstavnik turističnega združenja]

To je zametek razmišljanja »nazaj«, da ne moremo delati samo za lasten žep, za lasten profit, ampak da je treba tudi nekaj vrniti. [Strokovnjakinja]

Ukvarjam se s področjem družbene odgovornosti podjetja, razumem pa ga kot odgovoren odnos podjetja, da vlaga v okolje, $v$ katerem deluje. Zelo preprosto. [Predstavnica hotela 2]

Ali kot se je izrazil eden od strokovnjakov, "prostorska renta«.

Preprosto, da daš malo nazaj prostoru, ki ti je omogočil biznis. Se pravi, nekdo, ki je prišel sem, je prišel zato, da bo delal biznis. Zato se mi zdi prav, da tudi nekaj vrne temu prostoru, ker mu je omogočil, da je tukaj delal biznis. [...] Recimo temu prostorska renta, odškodnina za to, ker uporabljaš ... ker si vsiljivec v življenjskem prostoru lokalnega prebivalstva. Se pravi, prišel si sem, tukaj delaš biznis, vse lepo in prav, saj smo ti rekli, da lahko, ampak zdaj ne samo iztisniti soka, zbežati in tu pustiti olupek. Naj še malo soka ostane tukaj. [Strokovnjak]

Izpostavljen je bil tudi poslovni interes, tj. da podjetja dejavnosti, ki so družbeno odgovorne, izvajajo tudi zato, ker jim to prinaša določene poslovne oziroma ekonomske koristi.

Tako bom rekla: te stvari delajo zaradi določenih poslovnih interesov ali pa zato, ker delujejo v tem okolju in mu nekaj vrnejo. [Predstavnica hotela 2] 
Omenjen je bil tudi vidik trajnosti, dolgoročnih učinkov, ki se tudi $\mathrm{v}$ teoriji neločljivo povezuje z vprašanjem družbene odgovornosti.

$\mathrm{Na}$ eni strani, ko pomisliš na družbeno odgovorno, pomisliš na dolgoročne vidike, enako pri trajnostnem razvoju, pomisliš na ljudi, na okolje, enako pri družbeni odgovornosti. Ta dva vidika se precej mešata. [Strokovnjakinja]

S tem v povezavi v enem izmed hotelov kot izhodišče za uveljavljanje svojih odgovornih praks izpostavljajo tri stebre: vprašanje zdravja in varnosti, družbe in etike ter naravnega okolja.

Hm, katere vidike vključuje? V naši družbi smo izpostavili tri stebre. Prvi steber je zdravje in varnost tako gostov kot zaposlenih, drugi steber je družba in etika, tretji pa naravno okolje. Tukaj je jedro in iščemo potencialne priložnosti, kjer lahko sodelujemo po svojih poslovnih zmožnostih. [Predstavnica hotela 2]

Pri opredeljevanju družbene odgovornosti je lokalna skupnost pogosto izpostavljena kot tisti deležnik, do katerega naj bi bila hotelska podjetja odgovorna. Med ostalimi deležniki so omenjeni gostje in zaposleni, v smislu usklajevanja oziroma prilagajanja njihovim potrebam pa tudi ustreznega finančnega ovrednotenja opravljenega dela.

[Je to torej tudi odgovornost do gostov?] Do gostov, do zaposlenih. Lepo je, ko ti kdo v trgovini reče: »Pri vas pa vse štima.« To je zame družbena odgovornost. Ko to kdo reče, potem je to to. Si na pravi poti. [Predstavnik hostla]

Predvsem to, da je zdravo razmerje med tem, kar da zaposleni, in tem, kar daš ti, se pravi, da začutiš tudi njegove potrebe. [...] $\mathrm{V}$ teh osmih mesecih, ko hočeš nekaj narediti, ko je sezona, razumeš tudi delavca, zaposlenega na drugi strani. Omogočiš mu, recimo, proste dneve in se poskušaš kljub povečanemu obsegu dela prilagoditi njegovim potrebam. To pomeni, da ga poslušaš in razumeš, da se pogovarjaš z njim in potem vidiš, kje je še manevrski prostor, da se potem prilagodiš, vidiš, ali potrebuješ dodatne zaposlene ali ne in tako naprej. [...] Potem je tudi finančni vidik, da tisto, kar se oddela, da je tudi motivacija in stimulacija ter se to $\mathrm{v}$ teh mesecih tudi pozna. [Predstavnica hotela]

Hotelska podjetja so lahko družbeno odgovorna tudi z zagotavljanjem dobrega plačila svojim zaposlenim. Po mojem mnenju 
bi bili posledično ljudje tudi manj nastrojeni proti turizmu kot gospodarski dejavnosti. [Predstavnik občine]

Strokovnjakinja s področja turizma je za izhodišče razmišljanja vzela Carollovo štiridimenzionalno opredelitev družbene odgovornosti podjetij, pri čemer ravni družbene odgovornosti razdeli na prostovoljni in neprostovoljni del. Slednji naj bi bil temelj zdravega delovanja vsakega podjetja - ekonomska učinkovitost in upoštevanje zakonodajne regulative.

Presenečena sem bila, da sta dve ravni družbene odgovornosti, ki nista prostovoljni, da ju definicijsko razumemo kot prostovoljni in neprostovoljni del. In šele po tem prideš do tiste prostovoljne, za katero sem jaz ves čas mislila, da je družbena odgovornost, ko presežeš ta kratkoročni profit, motiv in gledaš v lokalno skupnost in poskušaš financirati ali sofinancirati nogometni klub v Izoli, poskušaš socialno ogroženega vzeti v svoj hotel. Jaz sem si kot družbeno odgovornost predstavljala ta del odgovornosti. Po prebranem pa sem navdušena nad tem - pa nisem ekonomist -, da je ona v svojih temeljih obvezna. In ta temelja, minimalni zahtevi, sta ekonomska učinkovitost in zakonodaja, ki jo je treba upoštevati. [Strokovnjakinja]

\section{Spreminjanje družbene odgovornosti hotelskih podjetij skozi čas}

Kontekst, v katerem je bila opravljena raziskava, je specifičen, saj ga je v preteklosti zaznamoval socialistični družbeni sistem. Zanj so bile značilne vrednote, ki so zagovarjale družbeno odgovornost podjetij, kar pa se je s prehodom na tržni sistem spremenilo. To pomeni, da je manj vlaganja v okolje, $v$ dejavnosti društev in druge aktivnosti.

Saj pravim, tega je zdaj bistveno manj, ker so podjetja manj družbeno odgovorna. $\mathrm{V}$ te zadeve pa je treba investirati, treba je obnavljati. Zato je zelo veliko podjetij vse to opustilo. [Predstavnik turističnega združenja]

Ni ga. Ni ga. [vlaganja v lokalno skupnost] Danes, kdorkoli ... To bi bilo mogoče zanimivo vprašati še eno ciljno skupino: društva. Društva, ki so včasih živela od tega. xxx je dal 500 evrov, xxx je dal 1.000 evrov, nekdo drug je dal 700 evrov in so imela letno kvoto, da so lahko nekaj naredila. Danes dobiti 100 evrov od podjetja kot donacijo, če ni ravno tvoj bratranec po prvem kolenu ali brat, je težko. Zelo, zelo, zelo težko. [Strokovnjak] 
In to so v preteklosti podjetja vedno počela in so vedno vlagala $\mathrm{v}$ kraje. Finančno so podpirala lokalna društva: balinarsko, kegljaško in tako naprej. Vzdrževala so površine, ki so bile namenjene javnosti, se pravi gostom, a so bile odprte tudi za javnost. Da ne govorimo o casinoju, ki je zgradil polovico ... se pravi, je vračal nazaj v širšo skupnost. Od urejanja cestnih površin do donacij, recimo rešilnih avtomobilov za bolnico Izola, mamografov, ne vem kaj še vse. Dobiček ni ostajal v podjetju, ampak se je vračal v družbo. [Strokovnjak]

$\mathrm{V}$ preteklosti je bil socializem in je bilo drugače. Je bilo veliko društev, ki so jih različna podjetja bistveno bolj financirala. Zdaj je teh sredstev, če pogledamo razpise, ki jih gledam za svoje društvo, bistveno manj ... Luka Koper, ki ima program "Živeti s pristaniščem «, nekaj pomaga. Banka Koper, ki daje po 50, 100 evrov, če zaprosiš. Ampak drugače ... [Predstavnik Turističnega združenja]

Po drugi strani se izpostavlja, da postaja družbena odgovornost (ponovno) vse pomembnejši pojem. Vprašanje pa je, koliko gre zgolj za nekaj modernega, aktualnega oziroma za marketinško strategijo, na kar opozarjajo kritični pogledi na družbeno odgovornost, ki jih predstavljamo v nadaljevanju.

Družbena odgovornost je bila del vsakega podjetja, društva, zveze. To je bila vrednota. Sistemska vrednota. Potem se mi pa zdi, da ko smo prišli v tržni sistem, je bilo treba vse to požagat, ker tržni sistem deluje po tržni logiki in na trgu se bodo vse stvari uredile. Trg bo vse rešil. To seveda ni res. In do tega smo prišli, da to ni res. In zdaj spet prihaja družbena odgovornost kot odgovor na neuspeh trga in regulacije, ki naj bi jo trg naredil. [Strokovnjakinja]

Jaz bi rekla tako, čedalje pomembnejša. Uveljavlja se. S tem, ko se kopičijo aktivnosti, merimo, spremljamo, objavljamo od leta 2012 dalje. Tega se kar precej nabere. Zdaj ko imamo jasno začrtane stebre, imamo aktivnosti razdeljene na te stebre. Tako vemo, v kakšno smer gremo, katere projekte podpiramo, kako se ti projekti skladajo z našo poslovno politiko na tem področju družbene odgovornosti. [Predstavnica hotela 2] 


\section{Kritike družbene odgovornosti hotelskih podjetij v praksi}

Deležniki so izpostavili tudi kritike družbene odgovornosti podjetij, načina delovanja v praksi, ko se predstavljanje kot družbeno odgovorno podjetje uporablja predvsem $\mathrm{v}$ namene promocije podjetij, dejanski vložek v okolje pa je majhen.

Danes je zelo moderno imeti certifikat družbeno odgovorno podjetje. S tem se kitiš, napišeš ček za 1.000 evrov in te slikajo vse televizije. To je marketing. To je investicija v marketing. To zame ni ... mislim, je, je del tega, ampak ni pa to tista iskrena družbena odgovornost. To je prezenca, forma, kako smo mi fajn, kako smo mi družbeno odgovorni, v resnici pa je to drobiž. [Strokovnjakinja]

Prevladuje finančni interes, dobiček, dolgoročne družbene koristi pa po mnenju različnih deležnikov niso nekaj, na kar bi bila hotelska podjetja pozorna.

In ko pomislim na vidik dolgoročnosti, ga ni: jih ne zanimajo dolgoročne zaposlitve, jih ne zanimajo dolgoročni rezultati, nič dolgoročnega jih ne zanima. Samo kratkoročno, kako lahko čim več profita ustvarijo. [Strokovnjakinja]

Danes je zadeva bistveno drugačna. Prihajamo na poslovni odnos: kaj se meni splača? [...]. Se pravi, vsako stvar gledamo striktno skozi ozek komercialni interes. To pomeni, da smo se, če gledam kapitalistično družbo, vrnili na sam začetek; ne tja, kjer je zdaj kapitalistična družba na zahodu, ampak tja, kjer je bila ta zahodna družba pred stotimi leti. Tudi na zahodu so sprevideli, da je treba z družbo sodelovati, ji pomagati, [vanjo] vlagati. [Strokovnjak]

Ravno ta vidik, ki je pomembnejši, ekonomski vidik, ki ga imajo različna podjetja. Prej, ko je bil socializem, ekonomski vidik ni bil tako pomemben. Vsem je šlo dobro, Intereuropi in vsem drugim. Zato se je lažje dajalo. Je bilo malo več tega. Zdaj pa so različni lastniki in ti od svojih upravljavcev, managerjev zahtevajo, da prinašajo prihodke, dobičke. In zdaj bo zagotovo izziv prepričati jih, da imajo ekonomsko korist, da je to lahko tudi vzrok, da so bolj družbeno odgovorni. [Predstavnik turističnega združenja] 
Žal v večji meri opažam družbeno neodgovornost kot pa odgovornost. Največjo težavo vidim v tem, da se v hotelskih podjetjih na Obali dogajajo pogoste lastniške spremembe, to pa negativno vpliva na družbeno odgovorno ravnanje podjetij. Lastniki (in s tem direktorji) so osredotočeni predvsem na doseganje dobička, to pa se odraža v slabšem odnosu do zaposlenih, okolja in navsezadnje do občine. [Predstavnik občine]

\section{Sodelovanje $z$ lokalnim okoljem}

\section{Oblike sodelovanja}

Oblike sodelovanja hotelskih podjetij z lokalnim okoljem so različne. Pogosto gre za sodelovanje $\mathrm{z}$ lokalnimi organizacijami oziroma društvi v obliki brezplačnih storitev, kot so nočitve ali gostinske storitve, npr. pri organizaciji dogodkov, projektnem sodelovanju in podobno.

$\mathrm{Z}$ raznimi [dejavnostmi], recimo v okviru festivalov in tako naprej. Finančne podpore je bistveno manj, naredimo pa razne kompenzacije, recimo za nočitve, tudi s Turističnim združenjem, za novinarje, blogerje in take zadeve, ponudimo torej brezplačne nočitve. Če pa so projekti, seveda pomagamo, recimo z gostinskimi storitvami, s katerimi se vključujemo v te projekte. Torej smo tudi sami udeleženi. Mislim, da s tem nimamo težav. [Predstavnica hotela]

Hoteli nudijo tudi finančno podporo lokalnim društvom pri organizaciji športnih in kulturnih prireditev ter drugih dogodkov. Pri tem so izpostavljene koristi, ki jih tako sodelovanje prinaša hotelskim podjetjem.

Hotelska podjetja prek sponzorstva podpirajo predvsem tiste prireditve, od katerih imajo korist v smislu povečanega števila gostov. [Predstavnik občine]

Tu so še društva, ki delujejo v zaledju. Se pravi, da podpremo gasilsko veselico z donacijami pa karnevale in športne aktivnosti v povezavi z morjem. Smo podporniki raznih jadralskih projektov. Od tega imamo tudi neposredno korist. Za velikonočno regato vedno nekaj damo. Zdaj se menimo za regato v Izoli, da bi nekaj dali. Sodelujemo z Avditorijem, ko so v igri večji prireditveni dogodki, recimo Melodije morja in sonca, ognjemet na vrhuncu sezone - take stvari tudi finančno podpremo. Sodelujemo tudi z 
Obalnimi galerijami. Gledamo malo na to. Predvsem v tem hotelu je pomemben ta kulturni vidik, saj smo v neposredni bližini Pirana. Tudi z društvom Anbot smo že sodelovali pri določenih projektih. Z Morigenosom se povezujemo glede morja in delfinov. [Predstavnica hotela 2]

Zaznati je mogoče tudi humanitarne pobude, ki jih lahko umestimo v kontekst socialnega turizma, kot npr. sodelovanje pri organizaciji letovanja za socialno ranljive družine. V spodnjem primeru je bil izpostavljen tudi etični vidik, vprašanje etičnosti uporabe tovrstnih akcij v promocijske namene.

Ja, ja. Ampak s tem se ne hvalimo toliko. Je občutljiva tema. Kje je zdaj tista meja, da se boš pohvalil. [...] Potem smo se skupaj odločili za Zvezo prijateljev mladine, tako da peljemo družine za Pomežik soncu. Lani smo tri družine pripeljali sem. In potem punce iz marketinga, "gremo jih slikat«. Ampak ne gre, ne delamo tega zaradi lastne promocije, da bi bili boljši. To narediš iz altruističnega [vzgiba], pomagaš neki organizaciji. Na njihovo pobudo pa ja. Ena družina je napisala zelo prijazno pismo, in če bi želeli ali pa dovolili objavo, to potem damo. Da pa bi jih v to silili ... [Predstavnica hotela 2]

Iz okolja prihaja veliko pobud, prošenj po podpori določenih dejavnosti. Izpostavljeno je bilo, da hoteli podprejo tiste, ki se vsebinsko skladajo s smernicami njihovega delovanja.

Ja, seveda podpiramo. Seveda v mejah, ki jih lahko nadzorujemo. Morate vedeti, da je teh želja, interesov veliko. Dogodkov je v tem prostoru ogromno, zato je treba narediti izbor, kaj podpirati in česa ne. Pri tem sledimo usmeritvam, ki smo si jih zadali, tako da smo aktivno udeleženi, ne pa povsod. [...] Ja, moram reči, da zelo [različno]: športno-turistične projekte podpiramo bolj, kulturne pa malo manj. Tako je zato, ker je v Portorožu res dobre kulture manj kot v Piranu. Pritiskov je pa ogromno. In vsak, ki bi želel nekaj izpeljati, se obrne tudi na nas. Težko je selekcionirati. [Predstavnica hotela 3]

Pomembno besedo pri tem imajo vodilni managerji.

[...] Dve leti je, odkar imamo predsednika uprave, odkar je prišel. Sem ga vprašala, kakšna je njegova vizija družbene odgovornosti. Na takih letnih pogovorih se pogovorimo, v katero smer 
naj bi šli. Jasno mi je odgovoril: Zveza prijateljev mladine ali botrstvo. Odločite se, eno ali drugo bom podprl. [Predstavnica hotela 2]

Tudi zaposleni imajo v nekaterih primerih vlogo pri izboru pobud, ki jih bo hotelsko podjetje podprlo.

Nekateri, ki so vključeni v društva, dajo interno pobudo, če bi se lahko kaj podprlo. Recimo, veslaško društvo je bilo tukaj, pa tudi nogometu smo dali. Pa zamaške smo zbirali za Nika, tudi za nogometno akcijo. Pa smo imeli akcijo zbiranja pomoči za poplavljena območja na Balkanu, ker je bilo veliko družin, ki tukaj delajo in imajo tam sorodnike ... Tako da tudi te stiske ... [Predstavnica hotela 2]

\section{Percepcija sodelovanja}

Na področju sodelovanja z lokalnim okoljem je izpostavljenih veliko izzivov, predvsem pri sodelovanju in povezovanju deležnikov - tako hotelov z občino in s turističnim združenjem kot tudi povezovanje hotelov med seboj. Večkrat je bila izpostavljena potreba po več in boljšem sodelovanju, povezovanju deležnikov. Čeprav sodelovanje obstaja, so hoteli pogosto zaprti vase.

Premalo sodelovanja, premalo dogodkov. Občino bi lahko dvignili veliko višje, kakor je, a en sam tega ne more. [Predstavnica hostla]

In seveda [je pomembno] tudi sodelovanje z zunanjimi partnerji ali z nam podobnimi podjetji. Seveda smo odprti glede tega, še posebej kar se tiče občine, pri raznih podjetjih. [...] Ampak še vedno mislim, da smo preveč zaprti in da bi moralo biti tega še več. Mislim, da še vedno vsak gleda preveč samo nase in da je premalo sodelovanja. [Predstavnica hotela]

Gre mogoče tudi za to, da bi morala občina in turistično združenje bistveno več sodelovati - tukaj vidim premalo sodelovanja [...]. Ampak mislim, da je še največja težava $v$ tem, da ni tistega pravega, da je ogromno manevrskega prostora za sodelovanje med občino in turističnim združenjem. Samo [sodelovanje] med hotelom in občino ter med hotelom in turističnim združenjem ni dovolj. Moral bi obstajati trikotnik. Tukaj vidim primanjkljaj. [Predstavnica hotela] 
Kljub zgoraj izpostavljenim izzivom sodelovanje že obstaja.

Z občino ogromno sodelujemo. [Predstavnica hotela]

Z lokalno turistično organizacijo sodelujemo zelo intenzivno in konstruktivno. Tu je pa res simbioza na zelo visoki ravni. [Predstavnica hotela 3]

Jaz mislim, da sodelujemo zelo, zelo dobro. Podjetje v lokalni skupnosti še vedno uživa velik ugled. Moramo vedeti, da smo pomemben zaposlovalec $\mathrm{v}$ tem okolju in dajemo vse, kar se le da ... Še vedno pa včasih pogrešamo malo več razumevanja $s$ strani upravnih služb ter korektnega in vizionarskega sodelovanja s strani občine in odločevalcev v okolju. Tam pa smo majhni. [Predstavnica hotela 3]

\section{Vzroki slabšega sodelovanja hotelskih podjetij z okoljem}

Čeprav sodelovanje obstaja, je na tem področju še veliko možnosti za izboljšave. Kje so vzroki slabšega sodelovanja hotelskih podjetij $\mathrm{z}$ okoljem? Pomemben vzrok deležniki vidijo v lastništvu hotelskih podjetij. Tuji lastniki, ki slabše poznajo značilnosti lokalnega okolja, oziroma lastniki, ki niso strateško usmerjeni v lokalno okolje, so do njega manj odgovorni, vanj ne vtisnejo svojega pečata in se ne povezujejo. Prav tako problematično je pogosto menjavanje lastništva.

Biti lokalni player po moje pomeni večjo verjetnost za višjo stopnjo družbene odgovornosti. In obratno, bolj kot si oddaljen, tam na Kitajskem daleč od oči, daleč od srca, mislim, da gre po tej logiki tudi družbena odgovornost. [Strokovnjakinja]

Pa bom najprej izpostavila slabo prakso portoroškega hotela, kjer je lastnik tujec, Hrvat. Udejanja to, kar hoče družbena odgovornost preprečiti: popolno odsotnost za zadeve in probleme ter lokalno skupnost kot tako. Gre za povsem kratkoročni vidik, strategijo zniževanja stroškov, ki ji je podrejeno celotno poslovanje podjetja. [Strokovnjakinja]

Morda je problem tudi v tem, da so določena podjetja - ne vsa-v lasti tujcev. In potem je težko pristopiti, saj tujci ne razumejo, se držijo zase in tako naprej. Prepričana sem, da je za sodelovanje še ogromno manevrskega prostora. Še vedno se vsak drži preveč zase. [Predstavnica hotela] 
Kot že omenjeno, so lastniki osredotočeni zgolj na poslovanje svojega hotela in ne vidijo širšega okolja. Dejstvo, da lastniki ne prihajajo iz lokalnega okolja, negativno vpliva na izvajanje družbene odgovornosti. [Predstavnik občine]

To je pa tisto lastništvo od zunaj; pa pravijo, ja, kdo ti bo pa odnesel hotel? Saj ni treba, da ti odnesejo hotel. Hotel bo vedno tukaj stal. Denar bo odtekal. In to se dogaja. Gre pa v druge namene, ne bo problem sponzorirati kje drugje. To je pač denarnica lastnika podjetja. Da bi pa on prišel na tisto stopnjo zavesti, da je treba vlagati tu, ker tu živi, bi pa moral biti lastnik [tu] najmanj 20, 30, 40 let ... Ali kakor rečemo temu: tradicija. Da se zavedaš. Ker to niso dolgoročne in strateške odločitve. Danes je prišel in je skušal stisniti - »ko ne bo šlo več, bom pa prodal«. To niso lastniki, ki se vidijo tukaj v naslednjih 50 letih. Strateški lastnik mora biti domač lastnik, a tudi domač lastnik je lahko trikrat slabši kot tuj, če je Janez namesto John. Kje piše, da je zato boljši? Smo ohranili podjetje v slovenskih rokah. So what, če je on iz Brežic. Če je iz Hamburga ali iz Brežic, denar bo šel iz Portoroža. Na ta patriotizem, kdo je lastnik, ne dam popolnoma nič. [Strokovnjak]

V preteklosti je bilo tovrstno sodelovanje boljše, kar je povezano tudi s preteklo politično ureditvijo (družbena lastnina), z boljšo gospodarsko klimo ter s kontinuiteto lastnikov (ni bilo tako pogostih lastniških sprememb). [Predstavnik občine]

Poleg razdrobljenosti in pomanjkanja enotnega vodstva sta bila izpostavljena tudi pomanjkanje zavedanja, da so hoteli del destinacije Portorož-Piran in občutenja povezanosti z destinacijo, ter usmerjenost vase, $v$ lastno finančno korist.

Razdrobljenost ter pomanjkanje enotnega vodstva in zavesti. V podjetju ni lojalnosti in pripadnosti, ne zato, »ker ne smem grdo govoriti o xxx hotelu, ker sem zaposlen v xxx hotelu«, ampak da s ponosom, ko te nihče nič ne vpraša, govoriš $\mathrm{o} x x x$, ker je to tvoj hotel. Čutimo pomanjkanje pripadnosti na ravni destinacije. Hoteli se ne počutijo več kot destinacija. Vsak ima svoj problem. [Strokovnjak]

To ni več turistično združenje [poudarjeno], ker ne združuje več. Lahko še na videz, ker so člani, ampak to ni več skupina šestih 
direktorjev, ki se usedejo skupaj in se zmenijo, kakšno ceno bodo določili za prihodnje leto. Niti pod razno. In zato ne more zaživeti ne letalska proga ne ladijski promet. Ker se ne morejo zmeniti. Ker jih tudi ne briga. Vsak gleda prvenstveno finance, ker imajo finančno zanko: "Jutri moram plačati račune, mene to ne zanima. Pusti ti beograjsko linijo pa Rim pa ne vem, kam bomo leteli. Jaz moram jutri plačati račune.«In ljudje so tako obremenjeni s tem, da jih razvojna vizija destinacije ne zanima več. In zato tudi ni nobenega drugega povezovanja oziroma odgovornosti do družbe. On so talasso, plavam tukaj v vodi, ne motite me. Tako čutim agonijo hotelirjev. Kako se iz tega izvleči?! To je vprašanje za milijon dolarjev. [Strokovnjak]

Med ključnimi deležniki je trenutno slab pretok informacij, kar lahko prav tako vpliva na slabo povezovanje.

Realno gledano, ne vidim veliko manevrskega prostora za izboljšave, saj je bilo v preteklosti sprejetih vse preveč napačnih odločitev. Morda je težava tudi v slabšem pretoku informacij med deležniki (občina, hotelska podjetja, lokalno prebivalstvo). [Predstavnik občine]

Kje so rešitve? Eden od strokovnjakov kot dolgoročno rešitev omenja izobraževanje in prikaz dobrih praks.

Ja, dolgotrajen proces, od 10 do 20 let. Z izobraževanji. Z izobraževanji in primeri. Ljudi je treba prijeti za roko in jim pokazati dobre prakse, kako je treba delati. Ljudi moramo pripeljati sem, da povejo: "Ne dela se tako. Tako moraš delati.« [Strokovnjak]

Manjši akterji so se izkazali za fleksibilnejše, bolj pripravljene na sodelovanje in različne pobude. Predstavniki manjših turističnih nastanitvenih obratov, kot so hostli, se samostojno angažirajo za boljše povezovanje med ponudniki na destinaciji.

Potrudimo se, kolikor je le mogoče, in prodamo svoj kraj. In je težko, ko pridejo gostje vprašat, kam iti, kaj videti, ter jih pošiljati v Izolo ali Koper. Mi bi jih radi imeli tukaj. Moramo delati s tem. Če zasledimo, da se tukaj karkoli dogaja, da kdo organizira karkoli, sodelujemo. Taka je trenutna situacija. [Predstavnica hostla]

Tudi z okoliškimi oddajalci apartmajev sodelujemo v smislu »ko 
napolnim sebi, pošljem k tebi« in to je obojestransko. Bolj na ta način. [Predstavnica hostla]

[I2] Želimo biti aktivni na tem področju. Tudi smo. Smo imeli eno akcijo ...

[I1] Ravno imamo eno, zdaj bomo naredili marketinško promocijo z drugim lokalom, ne našim. Tisti, ki pridejo k nam, imajo tam popust. Naredili smo tak letak, tako da imajo naši gostje, ker mi nimamo polpenzijona, možnost kam jest in pit, seveda za ugodnejšo ceno. Tako smo se dogovorili z lokali ...

[I2] Dobijo določen popust. Zapestnica. [Predstavnik hostla]

Dogajanje na destinaciji kot potencialni element povezovanja z lokalnim okoljem

Celovito doživetje destinacije je $\mathrm{z}$ vidika turistov zelo pomembno. $\mathrm{K}$ temu lahko pripomore prav uspešno sodelovanje in povezovanje deležnikov na destinaciji. Hotelskim podjetjem bi moralo biti v interesu, da bi se destinacija predstavljala kot celota in da bi pri tem izkoristili vse potenciale, $\mathrm{k}$ čemur lahko prispevajo tudi društva ter drugi organizatorji dogodkov in aktivnosti na destinaciji.

V lokalnem okolju delujemo tako, da je za nas destinacija pomembna; zavedamo se, da gost prihaja sem zaradi destinacije, ne zaradi hotela samega. Destinacija je tista, ki je prvi stik - marketinško in prodajno. Predstavimo se kot slovenska obala, Portorož in tako naprej. Zato povsem s poslovnega vidika na področju promocije delujemo s Turističnim združenjem. [Predstavnica hotela 2]

Imaš pa tudi druge hotele, druge ponudnike, ki razumejo, da lahko gasilsko društvo - ne govorim nujno za piransko občino ali turistično društvo, ki organizira kresovanje, to izredno dobro organizira za celotno destinacijo, kar je lahko atrakcija za moje goste. In recimo, da tisti večer jaz nimam potrebe organizirati animacijskih programov, če se na destinaciji dogajajo zanimive stvari. In vidim, da je tega preskoka v miselnosti premalo. Podjetja se premalo zavedajo, da bi lahko na ta način, če smo že ravno pri kleščenju stroškov, kaj prihranila na račun tega, da na destinaciji gostom ponudimo na primer kresovanje, v Strunjanu zdaj 
hotel organizira nordijsko hojo. Destinacija je tista, kjer se dogajajo atrakcije, ne pa hotel [poudarjeno] ali posamezen ponudnik. [Strokovnjakinja]

Sodelovanje bi bilo pomembno tudi pri izkoriščanju potencialov destinacije, zlasti v času izven osrednje turistične sezone. Zaradi sezonskega značaja turizma v Občini Piran je dobro sodelovanje na tem področju ključno pri oblikovanju ponudbe skozi vse leto. Strokovnjak je nasploh kritičen do aktualne ponudbe za goste na destinaciji: trgovske, kulinarično-gastronomske in kulturne; ta bi gostu na destinaciji omogočila celovito izkušnjo, ki ne bi bila omejena na dogajanje v hotelu.

Gre mogoče tudi za to, da bi morala občina in turistično združenje bistveno več sodelovati - tukaj vidim premalo sodelovanja. Delati bi morali na tem, da bi določeni festivali oziroma prireditve potekali tudi [poudarjeno] izven sezone. Opažamo, da imamo čudovito gledališče, pa ga ne uporabljamo. Priredimo nekaj dogodkov ob večjih praznikih, npr. za valentinovo in pust - tukaj pa se zadeva zaključi. [Predstavnica hotela]

Kar se tiče hotelske ponudbe, ni problema. Problem je vsa ostala ponudba. Ničesar nimamo. Gost stopi iz hotela, nimamo šopinga, nimamo dobre kulinarično-gastronomske ponudbe. Če dežuje, nimaš kam; nimamo ne muzeja ne galerije, nič. [Strokovnjak]

\section{Pogled zaposlenih na odnos hotelskih podjetij do lokalnega okolja}

V nadaljevanju bomo predstavili, kako odnos hotelskih podjetij do lokalnega okolja zaznavajo zaposleni, kar smo preverili s pomočjo anketnega vprašalnika.

Zaposleni v izbranih hotelskih podjetjih so izpolnili 215 anketnih vprašalnikov; 8 jih je bilo neustrezno izpolnjenih (anketiranec ni odgovoril na večino vprašanj), zato smo jih izločili iz nadaljnje analize. Analiza je bila torej opravljena na 207 ustrezno izpolnjenih vprašalnikih. Za potrebe statistične analize smo uporabili programsko opremo spss. V preglednici 3.1 prikazujemo osnovne demografske značilnosti anketirancev.

Iz preglednice 3.1 je razvidno, da večina anketirancev sodi v starostno skupino 26-36 let (31,9\%), med anketiranci pa prevladujejo žen- 
Preglednica 3.1 Demografske značilnosti anketirancev

\begin{tabular}{|c|c|c|c|}
\hline \multicolumn{2}{|l|}{ Spremenljivke } & \multirow{2}{*}{$\begin{array}{r}f \\
121\end{array}$} & \multirow{2}{*}{$\begin{array}{r}\% \\
58,50\end{array}$} \\
\hline Spol & ženski & & \\
\hline & moški & 81 & 39,10 \\
\hline \multirow[t]{5}{*}{ Starost } & $18-25$ & 43 & 20,80 \\
\hline & $26-36$ & 66 & 31,90 \\
\hline & $37-47$ & 50 & 24,20 \\
\hline & $48-58$ & 32 & 15,10 \\
\hline & 59 in več & 2 & 1,00 \\
\hline \multirow[t]{4}{*}{ Delovna doba v podjetju } & $0-10$ & 144 & 73,47 \\
\hline & nad 10 do 20 & 32 & 16,32 \\
\hline & nad 20 do 30 & 7 & 3,57 \\
\hline & nad 30 & 13 & 6,63 \\
\hline \multirow[t]{4}{*}{ Celotna delovna doba } & $0-10$ & 87 & 49,71 \\
\hline & nad 10 do 20 & 36 & 20,57 \\
\hline & nad 20 do 30 & 25 & 14,29 \\
\hline & nad 30 & 27 & 15,43 \\
\hline \multirow[t]{8}{*}{ Delovno mesto } & recepcija & 58 & 28,02 \\
\hline & kuhinja & 20 & 9,66 \\
\hline & gospodinjstvo & 16 & 7,73 \\
\hline & strežba & 57 & 27,54 \\
\hline & prodaja in marketing & 16 & 7,73 \\
\hline & wellness & 10 & 4,83 \\
\hline & kombinacija & 5 & 2,42 \\
\hline & ostalo & 19 & 9,18 \\
\hline \multirow[t]{4}{*}{ Oblika zaposlitve } & nedoločen čas & 109 & 52,70 \\
\hline & določen čas & 60 & 29,00 \\
\hline & honorarna zaposlitev & 1 & 0,50 \\
\hline & študentsko delo & 35 & 16,90 \\
\hline \multirow[t]{6}{*}{ Zaključena izobrazba } & osnovna šola ali manj & 9 & 4,30 \\
\hline & srednja strokovna šola (triletna) & 40 & 19,30 \\
\hline & srednja šola & 78 & 37,70 \\
\hline & visoka šola & 29 & 14,00 \\
\hline & fakulteta & 33 & 15,90 \\
\hline & magisterij, doktorat & 4 & 1,90 \\
\hline
\end{tabular}

ske $(58,5 \%)$. Slabe tri četrtine $(73,47 \%)$ anketirancev dela v izbranem hotelskem podjetju do 10 let. V izbranem vzorcu je najpogosteje navedena delovna doba $v$ podjetju 4 mesece, $v$ povprečju znaša dobrih 
Preglednica 3.2 Odnos hotelskega podjetja do lokalnega okolja: vidik zaposlenih

\begin{tabular}{lrrrrrrrr}
\hline Trditev & (1) & (2) & (3) & (4) & (5) & (6) & (7) & $(8)$ \\
\hline $\begin{array}{l}\text { Naše podjetje pomaga reševati raz- } \\
\text { lične socialne težave (npr. finančna } \\
\text { pomoč zaposlenim v stiski, zaposlo- } \\
\text { vanje invalidov). }\end{array}$ & 10 & 25 & 25 & 41 & 13 & 77 & 3,19 & 1,166 \\
\hline $\begin{array}{l}\text { Naše podjetje namenja sredstva v } \\
\text { človekoljubne (humanitarne) na- } \\
\text { mene. }\end{array}$ & 11 & 7 & 26 & 37 & 12 & 96 & 3,34 & 1,166 \\
\hline $\begin{array}{l}\text { V podjetju spodbujajo sodelovanje } \\
\text { zaposlenih v prostovoljskih aktivno- } \\
\text { stih (npr. prostovoljno sodelovanje } \\
\text { na lokalnih prireditvah). }\end{array}$ & 11 & 14 & 34 & 35 & 12 & 85 & 3,22 & 1,138 \\
\hline $\begin{array}{l}\text { Naše podjetje podpira športne, kul- } \\
\text { turne in druge projekte/aktivnosti v } \\
\text { lokalni skupnosti. }\end{array}$ & 9 & 4 & 22 & 75 & 35 & 45 & 3,85 & 1,023 \\
\hline $\begin{array}{l}\text { Naše podjetje sodeluje z lokalnimi } \\
\text { organizacijami (krajevna skupnost, } \\
\text { lokalno turistično društvo, lokalna } \\
\text { turistična organizacija). }\end{array}$ & 5 & 3 & 18 & 76 & 31 & 56 & 3,94 & 0,894 \\
\hline
\end{tabular}

Opombe Naslovi stolpcev: (1) sploh ne drži, (2) ne drži, (3) niti niti, (4) drži, (5) popolnoma drži, (6) ne vem/ne morem odgovoriti, (7) standardni odklon, (8) aritmetična sredina.

7 let, od te vrednosti pa njihova delovna doba v podjetju odstopa za 9 let in pol. Skoraj polovica anketirancev $(49,71 \%)$ ima do 10 let skupne delovne dobe, najpogosteje navedena skupna delovna doba znaša 10 let, v povprečju pa dobrih 14 let.

$28,02 \%$ anketirancev je zaposlenih na recepciji (receptor, vodja recepcije, portir), s $27,54 \%$ sledijo zaposleni na področju strežbe (natakar, pomočnik natakarja, vodja strežbe) ter zaposleni v kuhinji (9,66\%) (kuhar, kuharski pomočnik, pomočnik vodje, pomivalec, slaščičar). V skupini ostalih delovnih mest so animator, vzdrževalec, avdio-video tehnik, fizioterapevt idr. 6 anketirancev na vprašanje o delovnem mestu ni odgovorilo. Dobra polovica anketirancev je zaposlena za nedoločen čas $(52,7 \%), \mathrm{z} 29,0 \%$ sledijo anketiranci, ki so zaposleni za določen čas. Dva anketiranca na to vprašanje nista odgovorila.

V preglednici 3.2 prikazujemo vidik zaposlenih do odnosa izbranih hotelskih podjetij do lokalnega okolja. Pri vseh trditvah so povprečne vrednosti nad 3; najvišja vrednost je dosežena pri trditvi, ki 
Preglednica 3.3 Obveščenost o aktivnostih podjetja

\begin{tabular}{lrrrrrrr}
\hline Trditev & (1) & (2) & (3) & (4) & (5) & (6) & (7) \\
\hline $\begin{array}{l}\text { O dogajanju v podjetju sem redno obve- } \\
\text { ščen (npr. na sestankih, prek glasil ...). }\end{array}$ & 14 & 21 & 44 & 74 & 49 & 3,61 & 1,164 \\
\hline
\end{tabular}

Opombe Naslovi stolpcev: (1) sploh ne drži, (2) ne drži, (3) niti niti, (4) drži, (5) popolnoma drži, (6) standardni odklon, (7) aritmetična sredina.

Preglednica 3.4 Pomembnost zaposlitve v podjetju, ki sodeluje pri razvoju lokalne skupnosti

\begin{tabular}{lllllllr}
\hline Trditev & (1) & (2) & (3) & (4) & (5) & (6) & (7) \\
\hline $\begin{array}{l}\text { Pomembno mi je, da delam v podjetju, ki } \\
\text { sodeluje pri razvoju lokalne skupnosti. }\end{array}$ & 10 & 24 & 53 & 74 & 39 & 3,54 & 1,088 \\
\hline
\end{tabular}

Opombe Naslovi stolpcev: (1) sploh ne drži, (2) ne drži, (3) niti niti, (4) drži, (5) po-

se nanaša na sodelovanje hotelskega podjetja z lokalnimi organizacijami. Pri tej trditvi so anketiranci razmeroma enotni tudi glede na vrednost standardnega odklona $(s=0,894)$. Najnižja povprečna vrednost je dosežena pri trditvi, ki se nanaša na reševanje socialnih stisk zaposlenih, po drugi strani pa so pri tej trditvi precejšnje razlike med odgovori $(s=1,166)$. Izstopa tudi podatek, da veliko anketirancev ne ve, kako izbrano hotelsko podjetje, v katerem so zaposleni, sodeluje z lokalnim okoljem. To je še posebej izrazito pri prvih treh trditvah, ki se nanašajo na pomoč pri reševanju socialnih težav, namenjanje sredstev v humanitarne namene in spodbujanje prostovoljstva pri zaposlenih.

V preglednici 3.3 prikazujemo, kako zaposleni zaznavajo svojo obveščenost $o$ aktivnostih podjetja. Slabih $60 \%$ anketirancev se strinja s trditvijo, da so obveščeni, preostali pa menijo, da niso obveščeni. Tudi v tem primeru lahko trdimo, da so anketiranci precej neenotnega mnenja $(s=1,164)$. Pet anketirancev na to trditev ni odgovorilo.

V preglednici 3.4 prikazujemo, ali je za anketirance pomembno, da so zaposleni v podjetju, ki sodeluje pri razvoju lokalne skupnosti. Za dobro polovico anketirancev $(54,5 \%)$ je to pomembno, saj so izbrali odgovor "drži« oziroma "popolnoma drži«. Tudi v tem primeru lahko trdimo, da so anketiranci precej neenotnega mnenja $(s=1,088)$. Sedem anketirancev na to trditev ni odgovorilo.

Preverili smo tudi zadovoljstvo anketirancev s trenutno zaposlitvijo. Iz preglednice 3.5 je razvidno, da je velika večina anketirancev 
Preglednica 3.5 Zadovoljstvo s trenutno zaposlitvijo

\begin{tabular}{lrrrrrrr}
\hline Trditev & (1) & (2) & (3) & (4) & (5) & (6) & $(7)$ \\
\hline $\begin{array}{l}\text { Zadovoljen sem, da sem zaposlen v tem } \\
\text { podjetju. }\end{array}$ & 3 & 5 & 45 & 87 & 47 & 3,91 & 0,860 \\
\hline $\begin{array}{l}\text { Če bi imel možnost ponovno izbirati, bi } \\
\text { se še enkrat odločil za zaposlitev v tem } \\
\text { podjetju. }\end{array}$ & 7 & 13 & 50 & 70 & 47 & 3,73 & 1,033 \\
\hline $\begin{array}{l}\text { Razmišljam o tem, da bi pustil trenutno } \\
\text { službo. }\end{array}$ & 56 & 52 & 53 & 21 & 7 & 2,32 & 1,123 \\
\hline
\end{tabular}

Opombe Naslovi stolpcev: (1) sploh ne drži, (2) ne drži, (3) niti niti, (4) drži, (5) popolnoma drži, (6) standardni odklon, (7) aritmetična sredina.

Preglednica 3.6 Povezanost med obveščenostjo zaposlenih in vidikom zaposlenih o odnosu hotelskega podjetja do lokalnega okolja

\begin{tabular}{|c|c|c|c|}
\hline $\begin{array}{l}\text { Obveščenost o ak- } \\
\text { tivnostih podjetja }\end{array}$ & Odnos do lokalnega okolja - vidik zaposlenih & (1) & (2) \\
\hline \multirow{4}{*}{$\begin{array}{l}\text { O dogajanju v } \\
\text { podjetju sem re- } \\
\text { dno obveščen } \\
\text { (npr. na sestankih, } \\
\text { preko glasil ...). }\end{array}$} & $\begin{array}{l}\text { Naše podjetje pomaga reševati različne socialne } \\
\text { težave (npr. finančna pomoč zaposlenim v sti- } \\
\text { ski, zaposlovanje invalidov). }\end{array}$ & 0,31 & 0,000 \\
\hline & $\begin{array}{l}\text { V podjetju spodbujajo sodelovanje zaposlenih } \\
\text { pri prostovoljskih aktivnostih (npr. prostovoljno } \\
\text { sodelovanje na lokalnih prireditvah). }\end{array}$ & 0,19 & 0,010 \\
\hline & $\begin{array}{l}\text { Naše podjetje podpira športne, kulturne in dru- } \\
\text { ge projekte/aktivnosti v lokalni skupnosti. }\end{array}$ & 0,30 & 0,000 \\
\hline & $\begin{array}{l}\text { Naše podjetje sodeluje z lokalnimi organizaci- } \\
\text { jami (krajevna skupnost, lokalno turistično dru- } \\
\text { štvo, lokalna turistična organizacija). }\end{array}$ & 0,21 & 0,004 \\
\hline
\end{tabular}

Opombe Naslovi stolpcev: (1) korelacijski koeficient, (2) stopnja značilnosti.

zadovoljna s trenutno zaposlitvijo in da ne razmišlja o njeni zamenjavi.

V nadaljevanju smo preverili, ali obstaja statistično značilna povezanost med trditvijo, ki se nanaša na obveščenost zaposlenih o aktivnostih podjetja, in vidikom zaposlenih do odnosa izbranih hotelskih podjetij do lokalnega okolja. Povezanost smo preverjali s korelacijsko analizo (Spearmanov koeficient korelacije rangov). Rezultate prikazujemo v preglednici 3.6. V preglednici prikazujemo le tista razmerja, pri katerih se je pokazala statistično značilna povezanost. Iz preglednice je razvidno, da je povezanost $\mathrm{v}$ vseh primerih šibka oziroma zelo šibka, a statistično značilna. $V$ vseh primerih je povezanost pozitivna, kar smo tudi pričakovali. 
Preglednica 3.7 Povezanost med pomembnostjo zaposlitve v podjetju, ki sodeluje pri razvoju lokalne skupnosti, in vidikom zaposlenih o odnosu hotelskega podjetja do lokalnega okolja

\begin{tabular}{|c|c|c|c|}
\hline $\begin{array}{l}\text { Pomembnost } \\
\text { zaposlitve }\end{array}$ & Odnos do lokalnega okolja - vidik zaposlenih & (1) & (2) \\
\hline \multirow{5}{*}{$\begin{array}{l}\text { Pomembno mi je, } \\
\text { da delam v pod- } \\
\text { jetju, ki sodeluje } \\
\text { pri razvoju lokalne } \\
\text { skupnosti. }\end{array}$} & $\begin{array}{l}\text { Naše podjetje pomaga reševati različne socialne } \\
\text { težave (npr. finančna pomoč zaposlenim v sti- } \\
\text { ski, zaposlovanje invalidov). }\end{array}$ & 0,238 & 0,001 \\
\hline & $\begin{array}{l}\text { Naše podjetje namenja sredstva v človekoljubne } \\
\text { (humanitarne) namene. }\end{array}$ & 0,160 & 0,031 \\
\hline & $\begin{array}{l}\text { V podjetju spodbujajo sodelovanje zaposlenih } \\
\text { pri prostovoljskih aktivnostih (npr. prostovoljno } \\
\text { sodelovanje na lokalnih prireditvah). }\end{array}$ & 0,179 & 0,015 \\
\hline & $\begin{array}{l}\text { Naše podjetje podpira športne, kulturne in dru- } \\
\text { ge projekte/aktivnosti v lokalni skupnosti. }\end{array}$ & 0,194 & 0,008 \\
\hline & $\begin{array}{l}\text { Naše podjetje sodeluje z lokalnimi organizaci- } \\
\text { jami (krajevna skupnost, lokalno turistično dru- } \\
\text { štvo, lokalna turistična organizacija). }\end{array}$ & 0,193 & 0,009 \\
\hline
\end{tabular}

Opombe Naslovi stolpcev: (1) korelacijski koeficient, (2) stopnja značilnosti.

Nato smo preverili, ali obstaja statistično značilna povezanost med trditvijo, ki se nanaša na pomembnost zaposlitve v podjetju, ki sodeluje pri razvoju lokalne skupnosti, in vidikom zaposlenih do odnosa izbranih hotelskih podjetij do lokalnega okolja. Tudi v tem primeru smo povezanost preverjali s korelacijsko analizo (Spearmanov koeficient korelacije rangov). Rezultate prikazujemo v preglednici 3.7. V preglednici prikazujemo le tista razmerja, pri katerih se je pokazala statistično značilna povezanost. Iz preglednice je razvidno, da se je zelo šibka statistično značilna povezanost pokazala pri vseh trditvah, ki se nanašajo na odnos hotelskega podjetja do lokalnega okolja, kot ga zaznavajo anketiranci. $V$ vseh primerih je povezanost pozitivna, kar smo tudi pričakovali.

Preverili smo tudi povezanost med trditvijo, ki se nanaša na pomembnost zaposlitve v podjetju, ki sodeluje pri razvoju lokalne skupnosti, in zadovoljstvom zaposlenih s trenutno zaposlitvijo. Povezanost smo preverjali s korelacijsko analizo (Spearmanov koeficient korelacije rangov). Rezultate prikazujemo v preglednici 3.8, iz katere lahko razberemo, da obstaja šibka, a statistično značilna pozitivna povezanost med pomembnostjo zaposlitve v podjetju, ki sodeluje pri razvoju lokalne skupnosti, in zadovoljstvom s trenutno zaposlitvijo. 
Preglednica 3.8 Povezanost med pomembnostjo zaposlitve v podjetju, ki sodeluje pri razvoju lokalne skupnosti, in zadovoljstvom s trenutno zaposlitvijo

\begin{tabular}{llll}
\hline $\begin{array}{l}\text { Pomembnost } \\
\text { zaposlitve }\end{array}$ & Zadovoljstvo s trenutno zaposlitvijo & (1) & (2) \\
\hline $\begin{array}{l}\text { Zame je pomemb- } \\
\text { no, da delam v } \\
\text { podjetju, ki sode- }\end{array}$ & $\begin{array}{l}\text { Zadovoljen sem, da sem zaposlen v tem podje- } \\
\text { tju. }\end{array}$ & 0,337 & 0,001 \\
$\begin{array}{l}\text { luje pri razvoju lo- } \\
\text { kalne skupnosti. }\end{array}$ & $\begin{array}{l}\text { enkrat odločil za zaposlitev v tem podjetju. } \\
\text { kannost ponovno izbirati, bi se še }\end{array}$ & 0,242 & 0,001 \\
\hline
\end{tabular}

Opombe Naslovi stolpcev: (1) korelacijski koeficient, (2) stopnja značilnosti.

V nadaljevanju analize smo odnos hotelskih podjetij do lokalnega okolja, kot ga zaznavajo zaposleni, primerjali z zaključeno izobrazbo in delovnim mestom anketirancev ter preverjali, ali prihaja do statistično značilnih razlik. V tem primeru smo uporabili neparametrični test, tj. Kruskal-Wallisov H-test (enosmerna analiza variance na rangih), saj podatki ne zadostijo predpostavkam za uporabo parametričnega statističnega testa. Rezultati so pokazali, da ne prihaja do statistično značilnih razlik med zaznavanjem odnosa hotelskih podjetij do lokalnega okolja, doseženo izobrazbo in delovnim mestom anketirancev.

\section{Razprava in zaključek}

V prispevku nas je zanimal pogled ključnih deležnikov v Občini Piran na specifični vidik družbene odgovornosti hotelskih podjetij, in sicer odgovornost do lokalnega okolja. $V$ prvem delu je bil obravnavan pogled hotelskih podjetij, strokovnjakov, turističnega združenja in občine, $v$ drugem delu pa pogled zaposlenih.

Večdimenzionalnost koncepta družbene odgovornosti, ki je v definicijah večkrat izpostavljena (Skudiene in Auruskeviciene, 2012; Evropska komisija, 2011), se odraža tudi v pogledih strokovnjakov ter predstavnikov lokalne skupnosti in hotelskih podjetij, vključenih v raziskavo. Družbeno odgovornost namreč najpogosteje opredeljujejo široko - kot povračilo okolju, v katerem hotelska podjetja delujejo. Pri tem izpostavljajo tudi odgovornost do zaposlenih, dobaviteljev in akterjev, ki delujejo v lokalnem okolju.

Med zunanjimi motivi (Abeian idr., 2014) za družbeno odgovorno delovanje hotelov v lokalnem okolju sta bili izpostavljeni predvsem ekonomska korist in dobičkonosnost, ki ju tovrstno delovanje pri- 
naša, med notranjimi motivi pa so omenjene osebne vrednote vodilnega managerja pri izboru društev, ki jim bodo namenjena dobrodelna sredstva. To Abeian idr. (2014) umeščajo med altruistične motive, ki se kažejo v obliki korporativne filantropije. Oblike družbeno odgovornih dejavnosti hotelov v lokalnem okolju so raznolike in vključujejo humanitarne donacije, sponzorstva, podporo društev in dogodkov, vključevanje zaposlenih v aktivnosti v lokalnem okolju (npr. tekaška prireditev) ter sponzorstva v obliki brezplačnih storitev. De Miguel Molina idr. (2018), ki so opravili najaktualnejši pregled literature o vrstah družbeno odgovornih dejavnosti hotelskih podjetij v lokalnem okolju, navajajo vse zgoraj omenjene, poleg njih pa še nekaj drugih, kot npr. zbiranje sredstev za določen namen in štipendiranje. Med deležniki je torej družbena odgovornost vse bolj prepoznana kot pomemben element delovanja hotelskih podjetij, po drugi strani pa gre za princip delovanja, za katerega so izpostavili, da je bil v preteklosti oziroma v preteklem družbenem sistemu že zelo uveljavljen. Higgins-Desbiolles (2006) s tem v zvezi izpostavlja, da je bil v preteklosti, med drugim v okviru socialističnih družbenih sistemov, turizem razumljen ne zgolj kot »industrija « - kar je prevladujoč pogled danes -, temveč tudi kot pomemben dejavnik družbenih sprememb s pomembno vlogo v lokalni skupnosti. $V$ ta okvir lahko umestimo ugotovitve deležnikov, ki menijo, da so imela hotelska podjetja v Občini Piran v preteklosti pomembnejšo vlogo v lokalnem okolju, deležniki pa so bili bolj povezani med seboj in so enoviteje predstavljali destinacijo. Hotelska podjetja so pogosto usmerjena v lastno delovanje in finančne izzive, povezovanje in sodelovanje $z$ lokalnim okoljem pa sta manj uspešnoa, kot bi lahko bila. Kljub temu predstavniki podjetij navajajo različne aktivnosti sodelovanja $\mathrm{z}$ lokalnim okoljem v okviru družbene odgovornosti, o katerih pričajo tudi njihova letna poročila.

Kako pa na družbeno odgovornost hotelskih podjetij gledajo njihovi zaposleni? Pri preučevanju družbene odgovornosti so predvsem v storitvenih dejavnostih zaposleni pomemben deležnik, saj prav oni pomembno prispevajo $\mathrm{k}$ uspehu podjetja, zato je treba razumeti tudi njihovo zaznavanje družbene odgovornosti (Bauman in Skitka, 2012). Za dobro polovico zaposlenih, ki so sodelovali v raziskavi, je pomembno, da njihov delodajalec sodeluje pri razvoju lokalne skupnosti, analiza pa je pokazala tudi pozitivno statistično povezanost med pomembnostjo zaposlitve v podjetju, ki sodeluje pri 
razvoju lokalne skupnosti, in zadovoljstvom anketirancev s trenutno zaposlitvijo. Ta ugotovitev je v skladu $\mathrm{z}$ dosedanjimi raziskavami, ki so potrdile pozitivno povezanost med udejanjanjem socialnih vidikov družbene odgovornosti, nižjimi stopnjami fluktuacije zaposlenih in večjo pripadnostjo zaposlenih podjetju (Aguilera, Rupp, Williams in Ganapathi 2007; Heslin in Ochoa, 2008; Kim, Lee, Lee in Kim, 2010; Lee, Park in Lee, 2013; Youn, Lee in Lee, 2018). Skudiene in Auruskeviciene (2012) ugotavljata, da lahko delodajalci z izvajanjem družbeno odgovornih aktivnosti pozitivno vplivajo na motivacijo zaposlenih. Tudi Kim idr. (2017) ugotavljajo, da zaznavanje družbene odgovornosti s strani zaposlenih prispeva k večji pripadnosti podjetju in večji učinkovitosti na delovnem mestu.

Obenem na podlagi analize rezultatov ugotavljamo, da zaposleni v hotelskih podjetjih večinoma ne vedo, kako njihov delodajalec sodeluje z lokalnim okoljem. Tako npr. ne vedo, ali hotelsko podjetje pomaga reševati različne socialne težave in ali namenja sredstva v človekoljubne namene. Poleg tega ne zaznavajo, da jih podjetje spodbuja k prostovoljstvu. Predhodno predstavljene ugotovitve deležnikov, da bi lahko bilo sodelovanja z lokalnim okoljem več, so morda odraz tega, da je sodelovanja (pre)malo.

Morda hotelska podjetja ne posvečajo dovolj pozornosti obveščanju zaposlenih o tem, kako sodelujejo z lokalnim okoljem. Podjetja se morajo zavedati pomembnosti obveščanja zaposlenih o družbeno odgovornih aktivnostih, na kar opozarjajo tudi Bhattacharya, Sen in Korschun (2008). Pomen ustrezne obveščenosti lahko zaznamo tudi iz (sicer šibke) pozitivne povezanosti med obveščenostjo zaposlenih ter vidikom zaposlenih o odnosu podjetja do lokalnega okolja. Sklepamo lahko, da so zaposleni pozornejši na ta socialni vidik družbene odgovornosti, če so o njem obveščeni in imajo informacijo o tem, kako njihov delodajalec sodeluje $\mathrm{z}$ lokalnim okoljem. $\mathrm{Z}$ analizo smo ugotovili, da ni statistično značilnih razlik v zaznavanju odnosa podjetja do lokalnega okolja glede na delovno mesto in izobrazbo zaposlenih, ki so sodelovali v raziskavi. To ni presenetljivo, če predvidevamo, da so zaposleni na socialni vidik družbene odgovornosti pozornejši, če so o njem obveščeni.

Zaključimo lahko, da je pretok informacij o družbeno odgovornih aktivnostih zelo pomemben. Podjetja v svojih letnih poročilih sicer poročajo o tovrstnih aktivnostih, vendar je treba poskrbeti tudi za obveščanje zaposlenih, saj lahko podjetja na ta način vplivajo 
na zaznavanje socialnega vidika družbene odgovornosti pri zaposlenih. V tem pogledu lahko podjetja tudi s pomočjo izvajanja družbeno odgovornih aktivnosti utrjujejo pripadnost zaposlenih in vplivajo na njihovo delovno motivacijo, kar ima pozitiven učinek na uspešnost poslovanja. Družbeno odgovorne prakse in sodelovanje z lokalnim okoljem pa nenazadnje prinašajo dobrobit celotni destinaciji in vsem deležnikom, ki jo soustvarjajo.

\section{Literatura}

Abaeian, V., Yeoh, K. K., in Khong, K. W. (2014). An exploration of CSR initiatives undertaken by Malaysian hotels: Underlying motivations from a managerial perspective. Procedia: Social and Behavioral Sciences, 144, 423-432.

Aguilera, R. V., Rupp, D. E., Williams, C. A., in Ganapathi, J. (2007). Putting the $S$ back in corporate social responsibility: A multilevel theory of social change in organizations. Academy of Management Review, 32(3), 836-863.

Back, K., Lee, C. K., in Abbott, J. (2011). Internal relationship marketing: Korean casino employees' job satisfaction and organizational commitment. Cornell Hospitality Quarterly, 52(2), 111-124.

Barney, J. (2001). Resource-based theories of competitive advantage: A ten-year retrospective on the resource-based view. Journal of Management, 27(6), 643-650.

Bauman, C. W., in Skitka, L. J. (2012). Corporate social responsibility as a source of employee satisfaction. Research in Organizational Behavior, 32, 63-86.

Bhattacharya, C. B., Sen, S., in Korschun, D. (2008). Using Corporate Social Responsibility To Win The War For Talent. Mit Sloan Managemen Review, 49(2), 37-44.

Bohdanowicz, P., in Zientara, P. (2008a). Hotel companies' contribution to improving the quality of life of local communities and the wellbeing of their employees. Tourism and Hospitality Research, 9(2), 147-158.

Bohdanowicz, P., in Zientara, P. (2008b). Corporate social responsibility in hospitality: Issues and implications; A case study of Scandic. Scandinavian Journal of Hospitality and Tourism, 8(4), 271-293.

Branco, M. C., in Rodrigues, L. L. (2006). Corporate social responsibility and resource-based perspectives. Journal of Business Ethics, 69(2), $111-132$.

Carroll, A. (1979). A three-dimensional conceptual model of corporate social performance. Academy of Management Review, 4, 497-505.

Chen, M. H., in Lin, C. P. (2015). Understanding corporate philanthropy 
in the hospitality industry. International Journal of Hospitality Management, 48, 150-160.

Coles, T., Fenclova, E., in Dinan, C. (2013). Tourism and corporate social responsibility: A critical review and research agenda. Tourism Management Perspectives, 6, 122-141.

Dahlsrud, A. (2008). How corporate social responsibility is defined: An analysis of 37 definitions. Corporate Social Responsibility and Environmental Management, 15(1), 1-15.

de Grosbois, D. (2012). Corporate social responsibility reporting by the global hotel industry: Commitment, initiatives and performance. International Journal of Hospitality Management, 31(3), 896-905.

de Miguel Molina, B., de Miguel Molina, M., Segarra Oña, M., in Peiró Signes, A. (2018). Why and how hotel groups in luxury segments give back to their communities. International Journal of Tourism Research, 20(1), 100-114.

Evropska komisija. (2011). Obnovljena strategija Eu za družbeno odgovornost podjetij za obdobje 2011-14 (Сом(2011) 681 konč.). Bruselj: Evropska komisija.

Farrington, T., Curran, R., Gori, K., O'Gorman, K. D., in Queenan, C. J. (2017). Corporate social responsibility: Reviewed, rated, revised. International Journal of Contemporary Hospitality Management, 29(1), $30-47$.

Hamidu, A., Haron, M., in Azlan, A. (2015). Corporate social responsibility: A review on definitions, core characteristics and theoretical perspectives. Mediterranean Journal of Social Sciences, 6(4), 83-95.

Heslin, P., in Ochoa, J. (2008). Understanding and developing strategic corporate social responsibility. Organizational Dynamics, 37, 125144 .

Higgins-Desbiolles, B. F. (2006). More than an 'industry:' The forgotten power of tourism as a social force. Tourism Management, 27(6), 11921208.

Kasim, A. (2004). BESR in the hotel sector international. Journal of Hospitality \& Tourism Administration, 5(2), 61-83.

Kasim, A. (2006). The need for business environmental and social responsibility in the tourism industry. International Journal of Hospitality \& Tourism Administration, 7(1), 1-22.

Kasim, A. (2007). Towards a wider adoption of environmental responsibility in the hotel sector. International Journal of Hospitality and Tourism Administration, 8(2), 25-49.

Kim, H. R., Lee, M., Lee, H. T., in Kim, N. M. (2010). Corporate social responsibility and employee-company identification. Journal of Business Ethics, 95(4), 557-569.

Kim, H. L., Rhou, Y., Uysal, M., in Kwon, N. (2017). An examination of the 
links between corporate social responsibility (CSR) and its internal consequences. International Journal of Hospitality Management, 61, 26-34.

Lee, E. M., Park, S. Y., in Lee, H. J. (2013). Employee perception of csR activities: Its antecedents and consequences. Journal of Business Research, 66(10), 1716-1724.

Lesjak, M., Brezovec, T., in Fabjan, D. (2018). Strategija razvoja turizma v občini Piran do leta 2025 (Elaborat). Turistično združenje Portorož, Portorož.

Levy, S. E., in Park, S. Y. (2011). An analysis of cSR activities in the lodging industry. Journal of Hospitality and Tourism Management, 18(1), 147154.

Lund-Durlacher, D. (2015). Corporate social responsibility and tourism. V G. Moscardo in P. Benkendorff, (ur.), Education for sustainability in tourism: A handbook of processes, resources, and strategies (str. 5973). Heidelberg: Springer.

Lux, D. J., Jex, S. M., in Hansen, C. P. (1996). Factors influencing employee perceptions of customer service climate. Journal of Market-focused Management, 1(1), 65-86.

Mohammed, A., in Rashid, B. (2018). A conceptual model of corporate social responsibility dimensions, brand image, and customer satisfaction in Malaysian hotel industry. Kasetsart Journal of Social Sciences, 39, 358-364.

Park, S. Y., in Levy, S. E. (2014). Corporate social responsibility: Perspectives of hotel frontline employees. International Journal of Contemporary Hospitality Management, 26(3), 332-348.

Shafiqur, R. (2011). Evaluation of definitions: Ten dimensions of corporate social responsibility. World Review of Business Research, 1(1), 166176.

Sheldon, P., in Park, S. Y. (2011). An exploratory study of corporate social responsibility in the us travel industry. Journal of Travel Research, 50(4), 392-407.

Skudiene, V., in Auruskeviciene, V. (2012). The contribution of corporate social responsibility to internal employee motivation. Baltic Journal of Management, 7(1), 49-67.

Youn, H., Lee, K., in Lee, S. (2018). Effects of corporate social responsibility on employees in the casino industry. Tourism Management, 68, 328-335. 



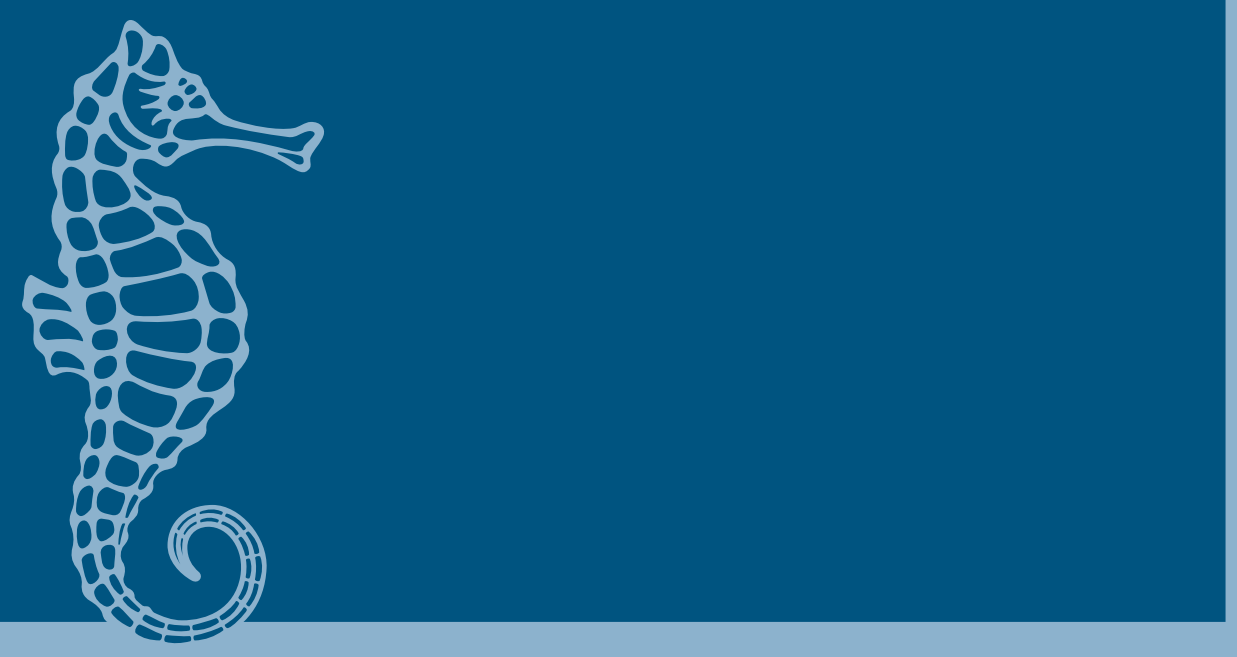

Založba Univerze na Primorskem 